Original paper

\title{
Geology and geochemistry of the Palaeozoic plutonic bodies of the Trans-Altay Gobi, SW Mongolia: implications for magmatic processes in an accreted volcanic-arc system
}

\author{
Pavel HANŽL'1*, Dash BAT-ULZII², Miroslav REJCHRT ${ }^{3}$, Jan KOŠLER ${ }^{4}$, Khasbazaar \\ BOLORMAA ${ }^{5}$, Kristýna HRDLIČKOVÁ ${ }^{1}$ \\ ${ }^{1}$ Czech Geological Survey, Leitnerova 22, 60200 Brno, Czech Republic; pavel.hanzl@geology.cz \\ ${ }^{2}$ Department of Geology and Mineralogy, Mongolian University of Science and Technology, Ulaanbaatar-46/520, Mongolia \\ ${ }^{3}$ Czech Geological Survey, Klárov 3, 11821 Prague, Czech Republic \\ ${ }^{4}$ Department of Earth Science, University of Bergen, Bergen, N-5007 Norway \\ ${ }^{5}$ Geological Investigation Centre, Songino Khayrkhan District, PO Box 37/307; Ulaanbaatar, Mongolia \\ * Corresponding author
}

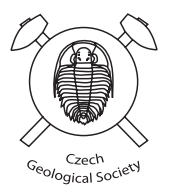

\begin{abstract}
Three geological domains (Gobi Tien Shan, Shargyn Gobi and Trans-Altay) have been distinguished in the Trans-Altay Gobi (SW Mongolia) consolidated during the Carboniferous and intruded by numerous plutons of the Devonian, Carboniferous and Permian ages. According to relationship to the Variscan orogenic cycle, pre-orogenic, syn-orogenic and post-orogenic intrusive bodies have been recognized. A pre-orogenic phase is represented by the Gurvan Khar Massif composed of geochemically primitive granodiorites that are geologically related to the relics of the Silurian-Devonian oceanic crust in the Zoolen Terrane (Shargyn Gobi Domain). Calc-alkaline intrusive rocks of I-type in the Gobi Tien Shan and Naran Sevest intrusive complexes exposed in the Gobi Tien Shan Domain are syn-orogenic to post-orogenic. Laser ablation U-Pb ICP-MS dating on zircon yielded an Early Carboniferous age for the Zamyn Belgekh Pluton, representing the largest plutonic body in this domain. Other plutons (Bayan Ayrag, Trans-Altay and Ikh Bayan) are of high-K chemistry, have Late Carboniferous to Permian age and are clearly post-orogenic. Minor gabbro massifs and small oval bodies of granites of the Ikh Bayan Massif in the Baytag Terrane (Shargyn Gobi Domain) are spatially related to the Trans-Altay shear zone of Late Carboniferous to Permian age. This zone accommodated dextral lateral movements between the Shargyn Gobi and Trans-Altay domains.
\end{abstract}

Keywords: Trans-Altay Gobi, Variscan orogeny, granite, geochemistry, laser ablation, Trans-Altay shear zone, geotectonic position Received: 31 March 2008; accepted 3 July 2008; handling editor: M. Štemprok

The online version of this article (doi: 10.3190/jgeosci.028) contains supplementary electronic material.

\section{Introduction}

The Palaeozoic and Mesozoic geological evolution of Central Asia was predominantly influenced by accretion of blocks of various geological character to the southern margin of Eurasia (e.g. Şengör et al. 1993; Windley et al. 2002; Jahn 2004). The orogenic belt has developed between the Siberian Block in the north, the Tarim Block in the south-west and the Sino-Korean Block in the south. It is known as the Central Asian Orogenic Belt (Mossakovsky et al. 1993) or the Altaids (Şengör et al. 1993 ) and it had evolved in a time span of 1000-250 Ma (Windley et al. 2007). It is composed of micro-continents, collapsed ocean basins, and associated accretionary volcano-sedimentary complexes, subduction-related volcanoplutonic arcs and anorogenic intrusive rocks (Hendrix et al. 1992). Şengör et al. (1993) interpreted this belt as a giant Palaeozoic subduction-accretion complex.
The Central Asian Orogenic Belt is characterised by an abundance of Palaeozoic and Mesozoic granitic intrusions as well as basaltic to rhyolitic volcanic rocks (e.g. Jahn et al. 2000) and is known as an important site of juvenile crustal growth during the Phanerozoic (Hu et al. 2000). The granitoids have a wide range of compositions and roughly show a temporal evolution from calc-alkaline, through alkaline to peralkaline series. The emplacement most of the granitic plutons fell between 500 to $120 \mathrm{Ma}$ (Jahn et al. 2000).

Even though the Altaids can serve as an ideal site for a case study of magmatic processes in accreted volcanic-arc systems, the geological, geochemical and isotopic data on granite bodies are irregularly distributed. Whereas numerous data exist from NW China (e.g., Allen et al. 1992; Wei et al. 1997; Windley et al. 2002; Yuan, et al. 2007) some from Kazakhstan and Russian Altay (Kovalenko et al. 2004), Mongolian Altay (Mitrofanov et 
al. 1981; Bibikova et al. 1992; Kozakov et al. 2007), eastern Gobi (Webb et al. 1999; Wang et al. 2003; Zhang et al. 2007) and southern Mongolia (Kozlovsky et al. 2005; Kovalenko et al. 2006), any data from the Trans-Altay Gobi are so far lacking. We present here new geological and geochemical data on granitic bodies in this remote, geologically little known area of SW Mongolia near its border with China.

\subsection{Geographic position of the Trans-Altay Gobi}

The Trans-Altay Gobi is situated SW of Edrengiin Nuruu Mts. in the SW corner of Mongolia. The studied area has been limited by the latitude $44^{\circ} \mathrm{N}$ in the $\mathrm{N}$ and the longitude $99^{\circ} \mathrm{E}$, in the $\mathrm{E}$ as well as by the Mongolian-Chinese state border in the $\mathrm{W}$ and $\mathrm{S}$ (Fig. 1). Morphologically, it is formed by the $\mathrm{E}-\mathrm{W}$ oriented Gobi Tien-Shan mountain range in the south, reaching maximum $2695 \mathrm{~m}$ a.s.l. (the summit of Atas Uul). The northern Edrengiin Nuruu range is a NW-SE trending structure with the highest point Ochir Khayrkhan Uul (1846 m a.s.l.) outside the studied area. The landscape between these mountain chains has a character of extensive uplands, in which no significant geomorphologic units can be distinguished. The northern slopes of the Gobi Tien Shan are lined by a system of endorheic intermountain depressions of the Shargyn Gobi. The lowermost point ( $\sim 550 \mathrm{~m}$ a. s. 1.) is located in the west in the Zagt Ikh Sayr valley at the Chinese border.

\subsection{Geological setting of the Trans-Altay Gobi}

The geologically very little known area of the TransAltay Gobi is formed by Palaeozoic volcanosedimentary and magmatic complexes locally covered by Mesozoic and Cenozoic sediments in the zone of junction between the Tien Shan and Altay orogenic belts. While the terrane division of Mongolia by Badarch et al. (2002) is generally used in a geological literature, our data from the Trans-Altay Gobi fit better with the geological subdivision of the South Mongolia by Ruzhentsev and Pospelov (1992) and Ruzhentsev (2001).

Based on a new geological survey (Šourek et al. 2003), three main Palaeozoic geological domains (Fig. 1) have been described in the Trans-Altay Gobi from north to south: Trans-Altay (TA) composed of Edren and Baaran

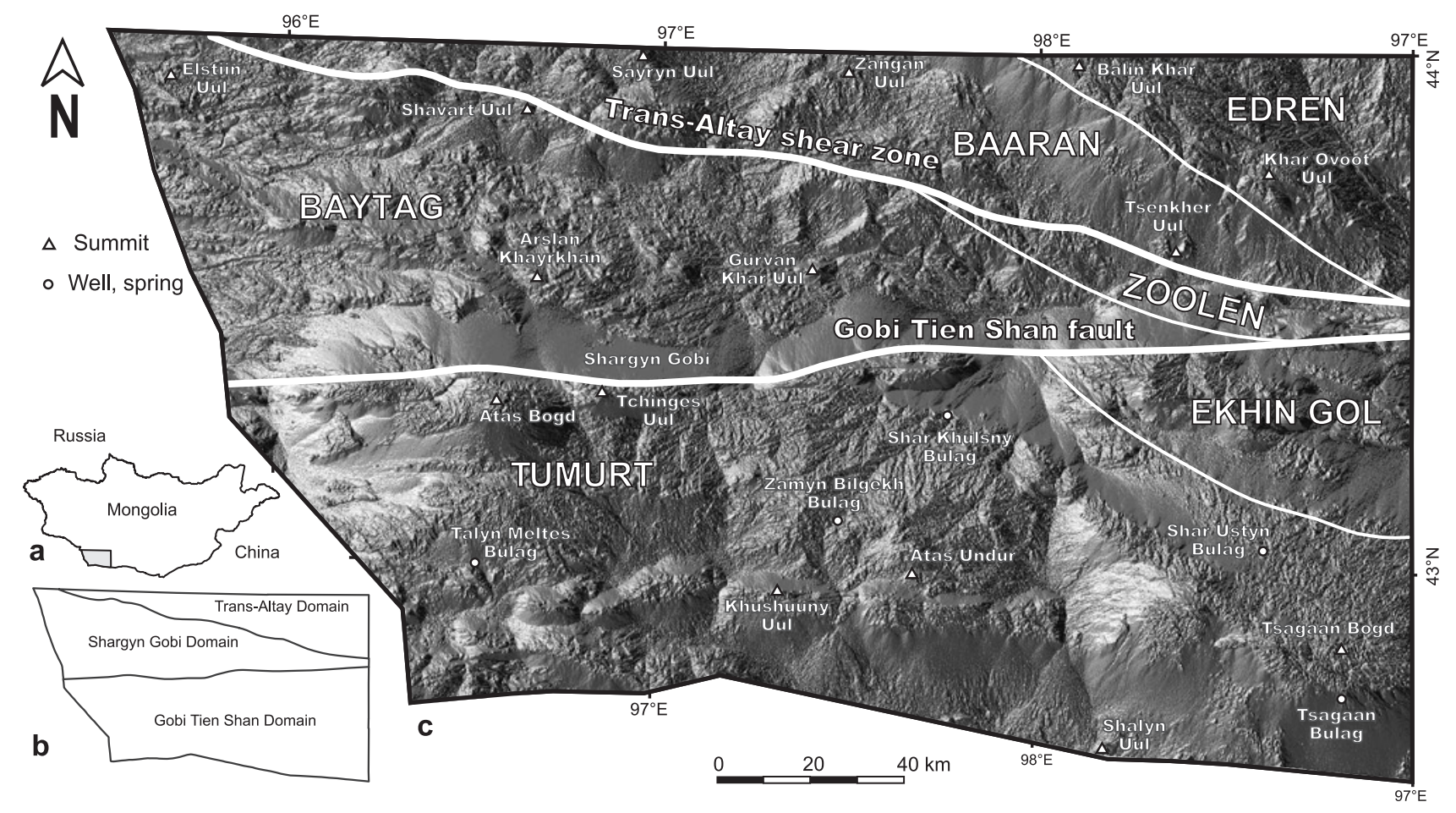

Fig. 1 Basic topography and geological nomenclature of the Trans-Altay Gobi: a - position of the Trans-Altay Gobi within the Mongolia; b - geological domains distinguished in Trans-Altay Gobi see also Tab. 1; $\mathbf{c}$ - digital elevation model of the Trans-Altay Gobi with important topographic points and subdivision to geological terranes (Edren, Baytag, Baaran, Zoolen, Ekhin Gol and Tumurt - set in capitals) and names of important geological boundaries (modified according to Ruzhentsev 2001; Badarch et al. 2002 and Hanžl et al. 2003). 
terranes, Shargyn Gobi (SG) formed by Zoolen and Baytag terranes and Gobi Tien Shan (GTS) containing Tumurt and Ekhin Gol terranes. Generally speaking, the Trans-Altay Domain is built by Devonian island-arc basalts in Edren Terrane (Lamb and Badarch 2001) and by the Devonian to Carboniferous volcanic rocks and siliciclastic to volcaniclastic sediments (Hanžl et al. 2003). The Shargyn Gobi Domain is composed of Early Palaeozoic deep-water sediments, ophiolite remnants and Early Carboniferous siliciclastic turbidites covered by Late Carboniferous to Permian volcanic and volcaniclastic rocks (Ruzhentsev 1985). While Baytag Terrane was interpreted as an island arc and Zoolen Terrane as an accretionary wedge terranes by Badarch et al. (2002), rock association (Ruzhentsev 2001) and geochemical data (Helo 2006) point to an ophiolitic character of the Zoolen Terrane, at least. The Gobi Tien Shan Domain is of backarc/forearc basin character with accreted Ordovician to Carboniferous volcanic rocks, as well as siliciclastic and volcaniclastic sediments. These were accreted together with metamorphosed rocks of unknown age newly mapped in the Atas Bogd range (Šourek et al. 2003; Hanžl and Krejčí 2008).

A correlation between various interpretations and terrane-related terminology is summarised in Tab. 1. The suture developed between the GTS and SG is masked by the Cenozoic sediments in the Shargyn Gobi depression and was reactivated by the $\mathrm{E}-\mathrm{W}$ trending Gobi Tien Shan fault system. The boundary between the SG and TA follows a NW-SE trending suture delineated by the exposures of serpentinite boudins and coloured mélange. Closing of this suture was post-dated by the intrusion of the Trans-Altay Intrusive Complex of (?) Early-Late Carboniferous age. The suture was reactivated in the latest stages of the Variscan tectonic activity and it could be interpreted as a dextral shear zone. This Trans-Altay shear zone resembles that described by Allen et al. (1992) from the northern Tien Shan in NW China.

\section{Methodology}

The presented geological interpretations and analytical data stem from available field documentation, maps and samples collected during the geological survey in the Trans-Altay Gobi (Šourek et al. 2003).

Petrography. The thin sections were prepared and described in Petrographical and Mineralogical Laboratory of the Geological Investigation Centre in Ulaanbaatar. Plagioclase basicity was determined by optical methods. Modal composition of rocks was computed by semiautomatic Eltinor 3 point counter.

Electron microprobe analyses were performed in the Joint Laboratory of Electron Microscopy and Microanalysis of the Masaryk University and the Czech Geological Survey (Brno). Operating conditions were $15 \mathrm{kV}$ accelerating voltage, and beam current of $80 \mathrm{nA}$.

Geochemistry. Samples (each about $1-2 \mathrm{~kg}$ in weight) were pulverized in the Central Geological Laboratory in Ulaanbaatar and analysed at ACME Labs in Vancouver. Major oxides, LOI, $\mathrm{C}$ and $\mathrm{S}$ were analysed by ICP-ES (0.2 $\mathrm{g}$ sample, $\mathrm{LiBO}_{2}$ fusion). Trace elements including REE were determined by ICP-MS (following a $\mathrm{LiBO}_{2}$ fusion or aqua regia digestion in the case of precious and base metals). The only wet major-element wholerock geochemical analyses performed at the Central Geological Laboratory in Ulaanbaatar are available for samples from the Bayan Ayrag Massif (Šourek et al. 2003). Whole-rock data were interpreted by the GCDkit software (Janoušek et al. 2006).

ICP-MS dating of zircons - samples and instrumentation. Samples of granite (c. $10 \mathrm{~kg}$ in weight) were crushed in iron mortar, heavy fractions were obtained by panning in the field. Zircons were extracted using heavy liquids and magnetic separation in laboratories of the Geomin Co., Jihlava. Hand-picked zircons were mounted in epoxy resin and polished. In order to better characterize their internal structure, all zircon grains

Tab. 1 Review of geological domains and terrane nomenclature of the Trans-Altay Gobi.

\begin{tabular}{|c|c|c|c|c|c|c|c|c|}
\hline \multicolumn{2}{|c|}{ this paper } & \multicolumn{2}{|c|}{ Ruzhencev (1985) } & \multicolumn{2}{|c|}{$\begin{array}{c}\text { Ruzhencev and Pospelov } \\
\text { (1992) }\end{array}$} & \multicolumn{2}{|c|}{ Tumurtogoo $(1997,2002)$} & $\begin{array}{c}\text { Badarch et al. } \\
\text { (2002) }\end{array}$ \\
\hline domain & terrane & domain & terrane & domain & terrane & domain & terrane & terrane \\
\hline \multirow{2}{*}{ Trans-Altay } & Edren & \multirow{4}{*}{ Transaltay } & & Edrengiin & Edrengiin Nuriin & \multirow{2}{*}{ Transaltay } & Edren & Edren \\
\hline & Baaran & & & \multirow{2}{*}{ Transaltay } & & & Aj Bogd & Baaran \\
\hline \multirow[b]{2}{*}{ Shargyn Gobi } & Zoolen & & & & & Nemegt & & Zoolen \\
\hline & Baytag & & & $\begin{array}{c}\text { South } \\
\text { Baruun } \\
\text { Khuurai }\end{array}$ & & Baruun Khuurai & Khayrkhan & Baytag \\
\hline \multirow{2}{*}{$\begin{array}{l}\text { Gobi Tien } \\
\text { Shan }\end{array}$} & Ekhin Gol & \multirow{2}{*}{$\begin{array}{l}\text { Gobi Tien } \\
\text { Shan }\end{array}$} & Ekhin Gol & \multirow{2}{*}{$\begin{array}{l}\text { South } \\
\text { Gobi }\end{array}$} & Ekhingol & \multirow{2}{*}{ Gobi Tien Shan } & & \multirow{2}{*}{ Atasbogd } \\
\hline & Tumurt & & Tumurtyn & & Tumurtyn & & & \\
\hline
\end{tabular}


were imaged in BSE prior to the analysis by laser ablation ICP-MS.

In this study we utilized a VG PlasmaQuad $2 \mathrm{~S}+$ instrument coupled to an in-house built $266 \mathrm{~nm}$ NdYAG laser at Memorial University, Newfoundland to measure $\mathrm{Pb} / \mathrm{U}$ and $\mathrm{Pb}$ isotopic ratios in zircons. The sample introduction system was modified to enable simultaneous nebulisation of a $\mathrm{Tl}^{233} \mathrm{U}$ tracer solution and laser ablation of the solid sample. The tracer solution was aspirated to the plasma in an argon carrier gas through a Micromist concentric nebuliser, Scott-type double-pass spray chamber and a T-piece tube attached to the back end of the plasma torch. A helium gas line carrying the sample from the laser cell to the plasma was attached to the T-piece tube.

The laser was focused c. $100 \mu \mathrm{m}$ above the surface of the sample and it was set up to produce energy of $0.8 \mathrm{~mJ} /$ pulse at a repetition rate of $10 \mathrm{~Hz}$, and masked to produce laser pits with $c .10 \mu \mathrm{m}$ diameter. The sample was mounted on a computer-driven motorised stage of a microscope and the stage was moved beneath the stationary laser beam to produce a square laser pit $(40 \times 40 \mu \mathrm{m})$ or line pit in the sample. The depth of pits varied from c. 10 to $15 \mu \mathrm{m}$. Typical acquisitions consisted of a 50s measurement of the gas blank and $\mathrm{Tl}^{2{ }^{23}} \mathrm{U}$ solution signal just before the start of ablation. The $\mathrm{U}$ and $\mathrm{Pb}$ zircon ablation signal, along with the continuous $\mathrm{Tl}^{2{ }^{23} 3} \mathrm{U}$ solution signal, were acquired for another $190 \mathrm{~s}$. Data for the 1065 Ma old zircon 91500 standard periodically acquired during the course of this study gave a ${ }^{238} \mathrm{U}^{2}{ }^{206} \mathrm{~Pb}$ age of $1069 \pm 8 \mathrm{Ma}(2 \sigma, \mathrm{n}=41)$.

Data were acquired in time resolved - peak jumping - pulse counting mode with one point measured per peak for masses 201 (flyback), 202 (Hg), 203 (Tl), 204 ( $\mathrm{Hg}+$ $\mathrm{Pb}), 205(\mathrm{Tl}), 206(\mathrm{~Pb}), 207(\mathrm{~Pb}), 233(\mathrm{U})$ and $238(\mathrm{U})$. Quadrupole settling time was $3 \mathrm{~ms}$ and the dwell time was $8.3 \mathrm{~ms}$ on each mass except for 207, where it was $24.9 \mathrm{~ms}$. The raw data were corrected for dead time of the electron multiplier ( $20 \mathrm{~ns})$, laser-induced elemental fractionation, instrument mass bias (using the $\mathrm{Tl}^{233} \mathrm{U}$ signal of the tracer solution) and gas and tracer solution blank. The amount of common $\mathrm{Pb}$ present in zircons analysed in this study was insignificant and accordingly, no common $\mathrm{Pb}$ correction was applied to the data. Errors on ages are quoted at 2 sigma level.

\section{Plutonic rocks of the Trans-Altay Gobi}

Bodies of the plutonic rocks that are irregularly distributed in the Trans-Altay Gobi are the most widespread in the GTS, common in SG and subordinate in the studied part of the TA (Fig. 2 and map enclosed in this Volume). There are neither relevant radiometric data nor trace element analyses except for a few ICP-MS laser ablation U$\mathrm{Pb}$ zircon ages of J. Košler (in Šourek et al. 2003). Thus the ages of plutons are estimated from their relationships with palaeontologically documented strata and interpretation of zircon laser ablation data. While the majority of plutons are spatially restricted to a given terrane, rocks of the Trans-Altay Intrusive Complex are distributed across the terrane boundaries. The names of plutonic complexes in Trans-Altay Gobi are used in accordance with Filippova et al. (1990b) and outlined in Tab. 2 (the term "intrusive complex" is used for extensive bodies composed of plutons of variable compositions). Modal and normative classifications of plutonic rocks are summarized in Fig. 3. Individual intrusive complexes are characterized in the order from the Trans-Altay Domain, through the Shargyn Gobi to the Gobi Tien Shan Domain.

Tab. 2 Outline of plutonic complexes exposed in the Trans-Altay Gobi.

\begin{tabular}{|c|c|c|c|c|c|}
\hline Name & Terrane & Petrography & Age & Enclaves & Subvolcanic dykes \\
\hline Bayan Ayrag & $\mathrm{TA}$ & Gabbro-diorite, monzonite, granite & $\mathrm{C} 1$ & rare & common \\
\hline Trans-Altay & TA, SG, GTS & Granodiorite, granite & $\mathrm{C} 1-2(\mathrm{P} ?)$ & rare & rare \\
\hline Gabbro massifs & TA, SG & Gabbro & $\mathrm{C} 2-\mathrm{P} 1$ & no & no \\
\hline Ikh Bayan & SG & Granite & $\mathrm{C} 2-\mathrm{P} 1$ & common & common \\
\hline Gurvan Khar & SG & $\begin{array}{l}\text { Metagranodiorite, metagranite, } \\
\text { cataclased }\end{array}$ & $\mathrm{D} ?$ & no & rare \\
\hline Tsagaan Bogd & GTS & Alkali feldspar granite to granite & $\mathrm{C} 2$ & no & no \\
\hline Gobi Tien Shan & GTS & $\begin{array}{l}\text { Gabbro, diorite, tonalite, granodiorite, } \\
\text { granite }\end{array}$ & C1 (P?) & common & common \\
\hline Naran Sevest & GTS & Granodiorite & $\mathrm{D} ?$ & common & common \\
\hline
\end{tabular}




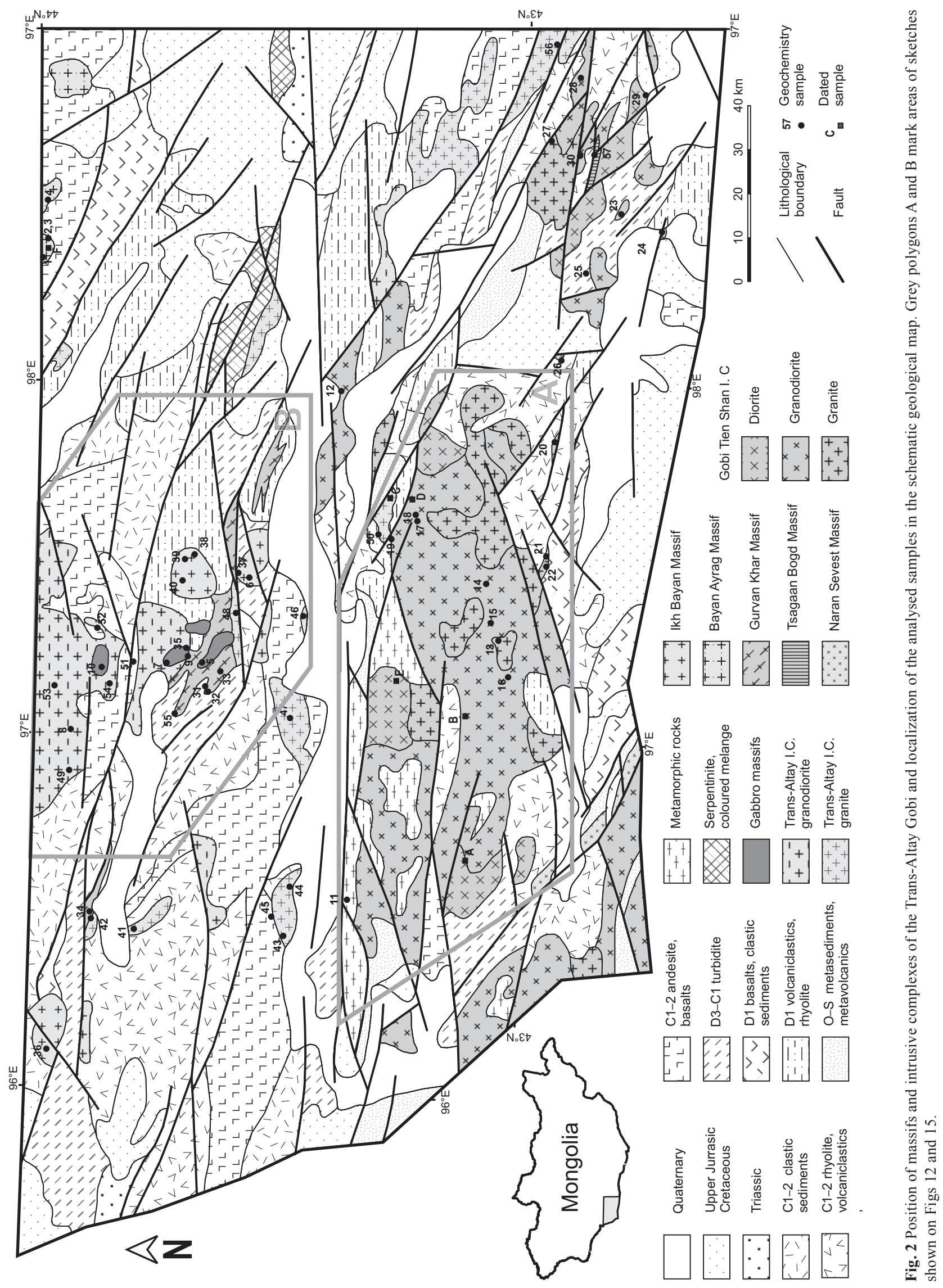




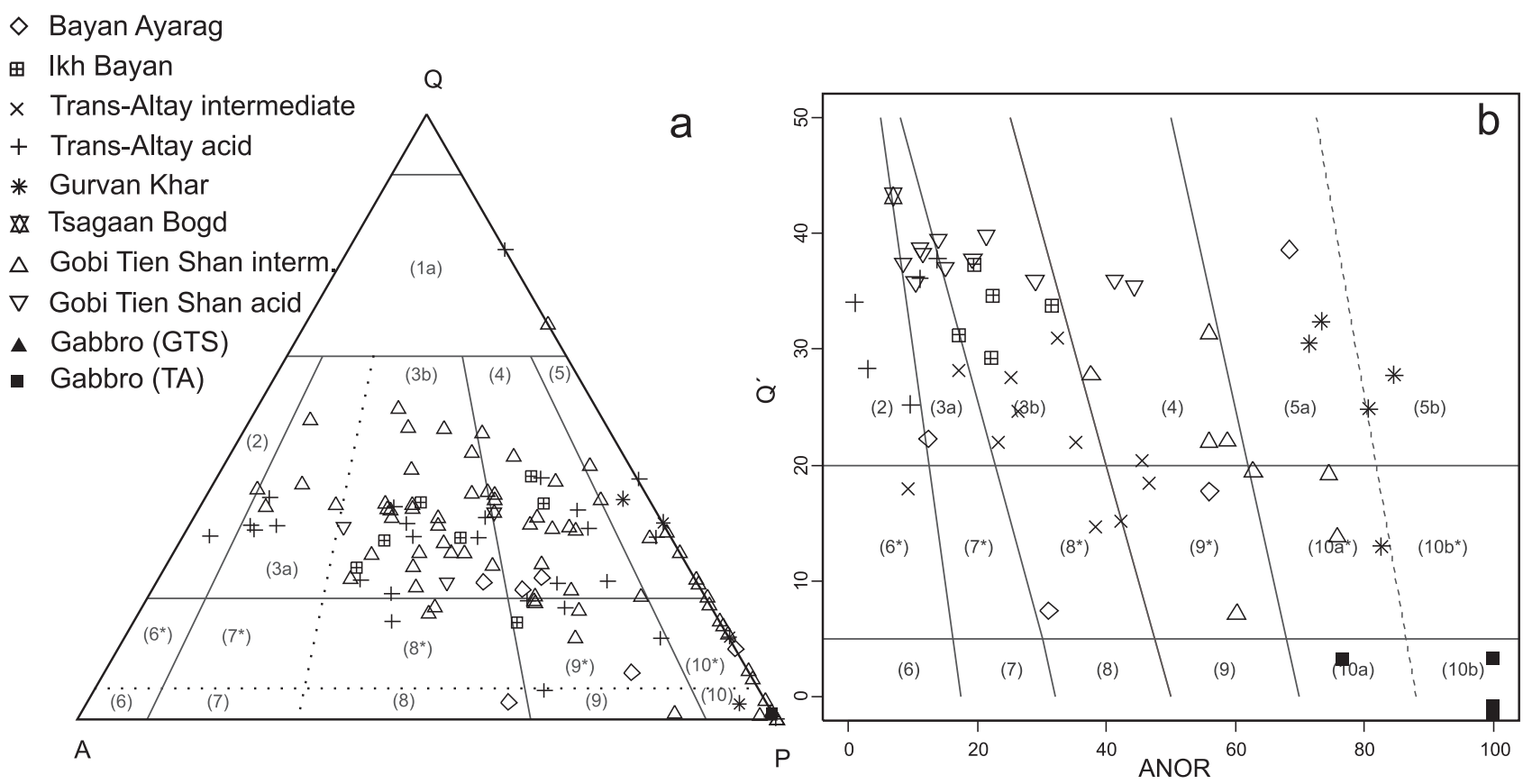

Fig. 3 Classification of plutonic rocks of the Trans-Altay Gobi in classification diagrams: a - QAP ternary plot based on modal compositions (Streckeisen 1976); b - Q'-ANOR mesonormative plot (Mielke and Winkler 1979; Streckeisen and Le Maitre 1979). Samples on both diagrams are not identical. Explanation: 2 - alkali feldspar granite, 3 - granite, 4 - granodiorite, 5 - tonalite, $6^{*}$ - quartz alkali feldspar syenite, $7^{*}-$ quartz syenite, $8^{*}$ - quartz monzonite, $9^{*}$ - quartz monzodiorite/quartz monzogabbro, $10^{*}$ - quartz diorite/quartz gabbro, 6 - alkali feldspar syenite, 7 - syenite, 8 - monzonite, 9 - monzodiorite/monzogabbro 10 - diorite/gabbro.

\subsection{The Bayan Ayrag Massif}

Bayan Ayrag Massif crops out on the SE edge of the Edrengiin Nuruu range north of the Khar Ovoot Uul in the NW corner of the studied region (Fig. 2). The massif is related to the Edren Terrane of the TA. It intruded andesites and rhyolites of the Early Carboniferous age (Filippova et al. 1990a). Geological mapping confirmed comagmatic nature of the plutonic and volcanic rocks. Massif has a zoned structure with biotite-hornblende (monzo-) gabbro and diorite core surrounded by hornblende-biotite granodiorite to monzodiorite and coarsegrained biotite granite rim. Subvolcanic dykes of basaltic composition accompanying the pluton are relatively common.

Granodiorites to monzodiorites, which prevail in the Bayan Ayarg Massif, are grey, medium-grained rocks of hypautomorphic textures composed of plagioclase (40-65 $\%$ ), K-feldspar (15-30\%), quartz (10-20\%), amphibole $(5 \%)$ and biotite (1-10\%). Elongated, oscillatory zoned laths of plagioclase have an oligoclase-andesine composition. Preferred orientation of feldspar crystals is common in more basic types. $\mathrm{K}$-feldspar is in places perthitic, quartz fills interstices between the feldspars. Green amphibole forms euhedral columns. Biotite flakes enclose feldspar and quartz. Mafic minerals are commonly altered to chlorite and minerals of epidote group. Zircon, apatite, magnetite and titanite are the common accessories. More acid varieties are represented by granodiorites ranging to granites. The rocks are medium-grained, indistinctively porphyritic. K-feldspar forms isometric, twinned phenocrysts set in medium-grained equigranular mosaic usually with microgranophyric texture composed of plagioclase, $\mathrm{K}$-feldspar and quartz. Biotite makes up to $5 \%$ of the rock volume, amphiboles are rare.

Gabbros to diorites are exposed in the centres of small oval bodies in the Bayan Ayarg Massif (see map enclosed in this Volume). The rocks are medium- to coarsegrained, dark grey, composed of elongated tabular grains of plagioclase $(55-70 \%)$, quartz $(0-10 \%)$, hornblende $(10 \%)$, pyroxene $(0-5 \%)$ and biotite $(2 \%)$. Preferred orientation of tabular plagioclases of andesine-labradorite composition is common, ophitic texture has been observed in several samples. Apatite, titanite and opaque minerals are common accessories. Chlorite, prehnite and sericite are secondary.

\subsection{Trans-Altay Intrusive Complex}

The Trans-Altay Intrusive Complex is represented by numerous plutonic bodies of variable, oval to irregular shapes. The largest body of this complex, known as the 
Sayryn Pluton, intruded the Late Carboniferous rocks. It has penetrated the terrane boundary of the TA and SG being exposed in the area between Sayryn Uul and Zangan Uul. In the SG, there are common ellipsoidal granitic bodies, which have intruded the Upper Carboniferous volcanosedimentary rocks and are related to the adjacent volcanic rocks. Smaller bodies of granites are widespread in the eastern part of GTS, where they intruded the Devonian and Carboniferous volcanosedimentary complexes. Borzakovskii and Suprunov (1990) supposed an Early to Middle Carboniferous age for the Trans-Altay Intrusive Complex; nevertheless, a Late Carboniferous to Permian age cannot be excluded. None or just a weak magmatic or submagmatic fabric has been observed in the bodies. Individual intrusions are usually composed of a single petrographic type of granite to quartz diorite composition. The enclaves are nearly missing. The number of subvolcanic dykes accompanying the granitic rocks is negligible. Granodiorites are cut by small elliptical gabbro bodies between the Sayryn Uul and Gurvan Khar Uul.

Hornblende-biotite granodiorites to quartz diorites dominate in the Sayryn Pluton, the largest body of this intrusive complex. It is of an irregular outcrop shape and composed of medium- to coarse-grained rocks. The rocks are composed of quartz (20-25\%), plagioclase (40-45 $\%$ ), K-feldspar (10-25\%), biotite (0-5\%) and amphibole (5-10\%). Long-prismatic to tabular grains of plagioclase (oligoclase) are polysynthetically twinned and oscillatorilly zoned. Typical is intense sericitization, particularly in the more basic rocks. Irregular grains of K-feldspar are poikilitic, enclosing both the plagioclase and hornblende. Hornblende is thickly columnar, reaching up to $1 \mathrm{~cm}$ in length. This mineral is often euhedral, usually chloritized and epidotized. Using the amphibole-plagioclase thermometer (Holland and Blundy 1994), the temperature of crystallization was estimated at $714-612{ }^{\circ} \mathrm{C}$. Biotite is chloritized with exsolutions of epidote and leucoxene. Accessoric are zircon, apatite and opaque minerals.

Biotite (leuco-) granites and granodiorites form a substantial part of the oval-shaped intrusions. These medium-grained rocks with subhedral to anhedral evengrained, locally porphyritic textures are composed of quartz (25-35\%), K-feldspar (40-50\%), plagioclase (15-30\%), biotite $(0-5 \%)$ and locally contain hornblende. Thick columnar to tabular plagioclases correspond to zoned oligoclase $\left(\mathrm{An}_{10}\right.$ at the margin and $\mathrm{An}_{19}$ in the centre). Irregular grains of K-feldspar are usually strongly perthitic. Sporadically occurring biotite is light brown. An opaque mineral, titanite, allanite and apatite appear as accessories, secondary minerals are epidote and sericite. Indistinct phenocrysts of embayed K-feldspar, granophyric intergrowths and rare spicular amphibole (Fig. $4 \mathrm{a}-\mathrm{b}$ ) are characteristic of alkali-feldspar granites.

\subsection{Ikh Bayan Massif}

Leucocratic and biotite granites to granodiorites of the Ikh Bayan Massif form circular bodies spatially limited to the northern part of the SG. They intruded undifferentiated volcanosedimentary sequences of the Devonian age and the Early Carboniferous siliciclastic turbidite sediments. The largest intrusion has almost $15 \mathrm{~km}$ in diameter and is rimmed by a distinct contact aureole. Granites to granodiorites (Fig. 3) represent main lithological types; rocks of diorite composition are subordinate, forming microdiorite enclaves. Xenoliths of volcanosedimentary rocks (now hornfelses) are frequent in granites along the contact aureole, which reaches several hundreds of meters in thickness. In xenoliths, hornfelses sporadically pass to migmatized gneisses. The granites are accompanied by frequent subvolcanic dykes of bimodal composition with a prominent NE-SW oriented trend.

Biotite (leuco-) granites and granodiorites are medium-grained, their texture is hypidiomorphic even grained to slightly porphyritic. Plagioclases (25-45 \%) and Kfeldspars (15-45\%) are frequently equally represented. The proportion of quartz in these rocks is $25-35 \%$ and of chloritized biotite 2-6\%; muscovite is exceptional. Amphibole appears only in a few samples, reaching up to $5 \%$. K-feldspar is tabular, often occurring in distinctly elongated usually twinned phenocrysts with uneven grain margins (Fig. 4c). The plagioclase (oligoclase) is slightly zoned and polysynthetically twinned. Accessory minerals are zircon, magnetite, garnet, titanite, apatite and fluorite. Secondary minerals are represented by epidote, chlorite, sericite and kaolinite.

\subsection{Gurvan Khar Massif}

The largest body of the Gurvan Khar Massif of an irregular outcrop shape is exposed NW of the Gurvan Khar Uul in the centre of the Shargyn Gobi Terrane. It is composed of hornblende-biotite metagranodiorite and biotite orthogneiss. Smaller bodies of similar rocks are exposed in tectonic slices along the faults subparallel with the Trans-Altay shear zone, where they are mylonitized and altered. The massif intruded volcaniclastic rocks of Silurian to Early Devonian age. The metagranodiorites are cut by oval bodies of gabbro and apophyses of red granites probably related to the Trans-Altay Intrusive Complex. The contact aureole developed around the massif in the Carboniferous flysh is indistinct and is influenced by later gabbro intrusions.

Hornblende-biotite metagranodiorite to biotite orthogneiss are grey to reddish grey, fine- to mediumgrained, composed of plagioclase (55-70\%), quartz (5-30\%), K-feldspar (5\%), biotite (5-8\%), and amphi- 

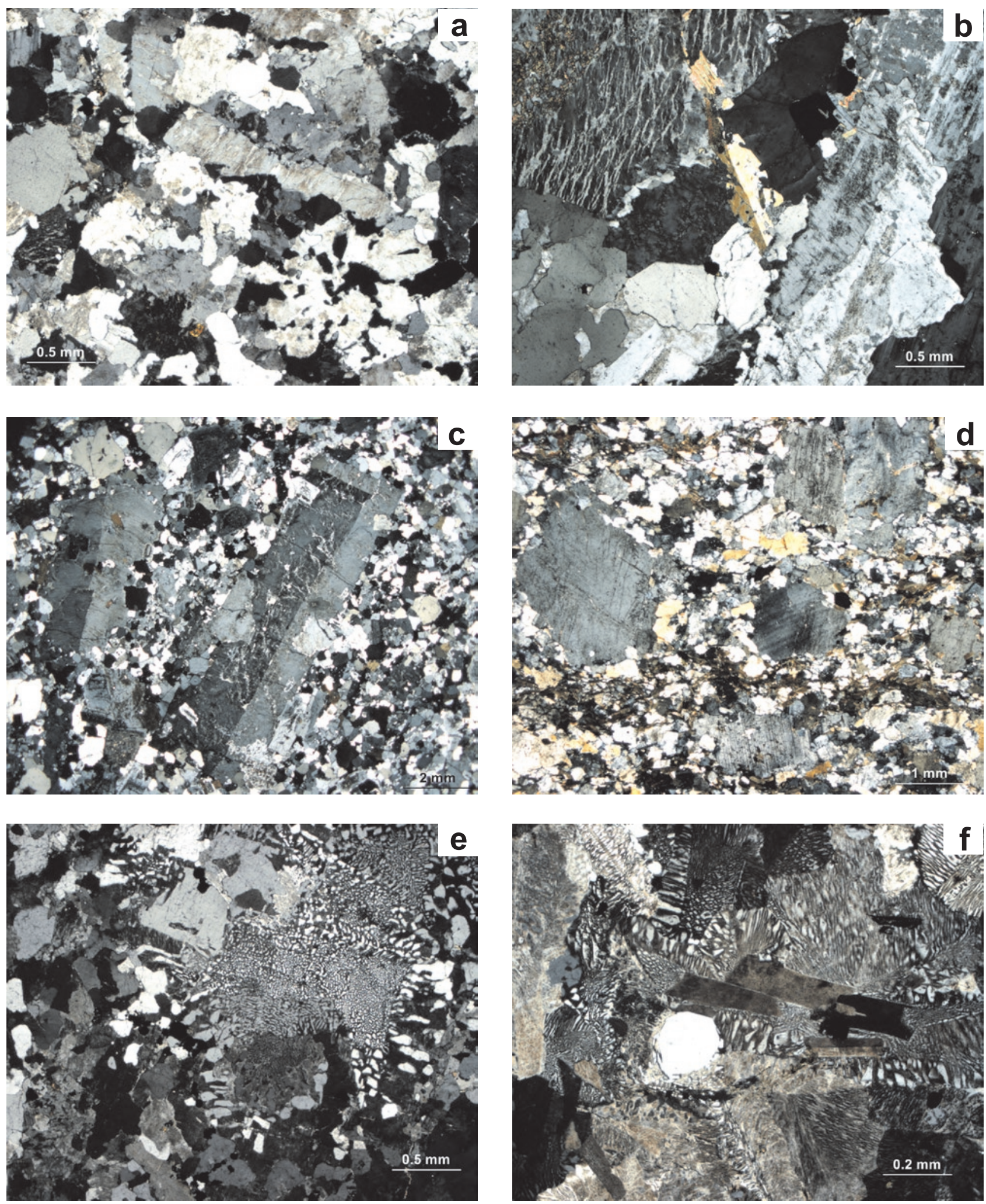

Fig. 4 Photomicrographs of selected granites from the Trans-Altay Gobi: a, $\mathbf{b}$ - examples of granites with alkaline affinity from the Trans-Altay Intrusive Complex; c - phenocrysts of strongly perthitic K-feldspars in granite from the Ikh Bayan Massif; $\mathbf{d}$ - orthogneiss from the Gurvan Khar Massif; e, f-examples of granophyric textures from granites of the Gobi Tien Shan Intrusive Complex. 
bole $(2-10 \%)$. The plagioclase forms tabular subhedral crystals with irregular margins, $\mathrm{K}$-feldspar is oval-shaped, biotite is brown, chloritized, anhedral quartz is recrystallized with uneven margins. Porphyroclastic texture is developed in some orthogneisses (Fig. 4d). Opaque minerals, decomposed titanite and exceptionally grains of oval garnet appear as accessories. The rocks are recrystallized with attendant development of metamorphic foliation. The strike of foliation follows the shape of the younger gabbro intrusions.

\subsection{Gabbro massifs}

Granites of the Gurvan Khar and Sayryn massifs (polygon B in Fig. 2) between the Gurvan Khar Uul and the Sayryn Uul are intruded by oval-shaped bodies of gabbro, which caused a great deal of alteration and deformation along their contacts. The gabbros are fine- to medium-grained, dark grey rocks. They are formed by plagioclase (42-80\%), clinopyroxene (0-35\%), olivine (5-21\%), and biotite (0-6\%). In some of the samples, also orthopyroxene is present. Brown biotite and light brown clinopyroxene enclose oval-shaped grains of olivine. Amphibole rims often appear around the pyroxene grains. Prismatic plagioclase corresponds to labradorite. Slight alteration is documented by the presence of talc, tremolite and carbonate. An opaque mineral occurs as an accessory.

\subsection{Gobi Tien Shan Intrusive Complex}

The Gobi Tien Shan Intrusive Complex crops out in several relatively isolated massifs that are arranged in the form of an E-W trending belt in the Gobi Tien Shan range. The Gobi Tien Shan Intrusive Complex is of Late Devonian to Early Carboniferous age (Filippova et al. 1990a, b). The largest body of this complex forms an EW elongated pluton (polygon A in Fig. 2) in the western part of a mountain range known as the Zamyn Belgekh Pluton (Batulzii et al. 2003). Plutonic bodies in the eastern part of the range are disrupted by numerous NW-SE oriented faults. The Zamyn Belgekh Pluton exceeds 100 $\mathrm{km}$ in length and reaches up to $40 \mathrm{~km}$ in width. In the eastern part, granites intrude the Early Carboniferous rocks as a partly independent circular body (Fig. 2). The primary intrusive contacts with the Early Devonian and Ordovician/Silurian volcaniclastic rocks along the northern and southern margins of the Zamyn Belgekh Pluton are usually modified by faults. Only a narrow zone of thermally-metamorphosed rocks containing microscopic andalusite is developed around the granites in the E part of the pluton. A wide zone of very fine-grained biotite gneisses with polygonal textures and common cordierite is exposed at the exocontact of the pluton in the NW parts of the Gobi Tien Shan range.

Biotite gneiss with garnet has been locally found in wall-rock xenoliths along the northern endocontact of the Zamyn Belgekh Pluton. The garnet is dominated by the almandine component with subordinate proportion of the pyrope molecule. The garnet zoning with rimward decrease in $\mathrm{Mn}$ and $\mathrm{Ca}$ contents can be interpreted as crystallization at rising temperature and decreasing pressure, which can correspond well with the conditions during the granite emplacement. Two phases of garnet growth was revealed in the larger grains, while smaller garnets crystallized during the later phase only. The crystallization temperature estimated on the basis of the biotite thermometer (Ferry and Spear 1978) at $\sim 680{ }^{\circ} \mathrm{C}$ corresponds to the range typical of the water-saturated melting (Clarke 1992). The metamorphic conditions of $\mathrm{T} \sim 700{ }^{\circ} \mathrm{C}$ and $\mathrm{P} \sim 8$ kbar computed by THERMOCALC (version 3.21; Powell and Holland 1985; Holland and Powell 1985, 1998; update February 2002) fail the recommended statistical tests. This can point to the disequilibrium between mineral phases in this exceptional garnet-bearing xenolith.

Granitic rocks of the Gobi Tien Shan Intrusive Complex intruded in the form of small apophyses and dykes metamorphic rocks (migmatized biotite gneiss and amphibolite) of unknown age occurring in the mountain ranges of the Atas Uul and Tchinges Uul in the NW.

The Gobi Tien Shan Intrusive Complex is formed by varied igneous rocks of gabbro, diorite, quartz diorite to monzodiorite, granodiorite and granite composition. The gabbros to gabbrodiorites are exposed as small, discrete bodies inside the granitic rocks but they also occur in the Lower Palaeozoic wall rocks and their genetic relation to the massif is ambiguous. Three main magmatic suites have been revealed by geological mapping (Šourek et al. 2003) inside this intrusive complex: biotite (leuco-) granite and granodiorite, locally granophyric; hornblende-biotite granodiorite to monzodiorite with mafic enclaves and biotite-hornblende diorite to gabbro. Contacts between the lithological types are usually transitional, and sometimes also untraceable. A typical feature of the Gobi Tien Shan Intrusive Complex is the intimate association of coexisting basic and acid igneous rocks and the evidence for their mutual interaction (magma mingling and mixing) in the form of lobate embayments, syn-plutonic dykes, swarms of mafic microgranular enclaves and disintegrated batches of mafic magma in the acid one (Fig. 5). Magmatic flow active during the lifespan of pluton is documented by magmatic foliation defined by schlieren, preferred orientation of mafic minerals and flattening of mafic enclaves. Submagmatic foliation is developed in the plutonic rocks especially along the northern contact of the Zamyn Belgekh Pluton, 

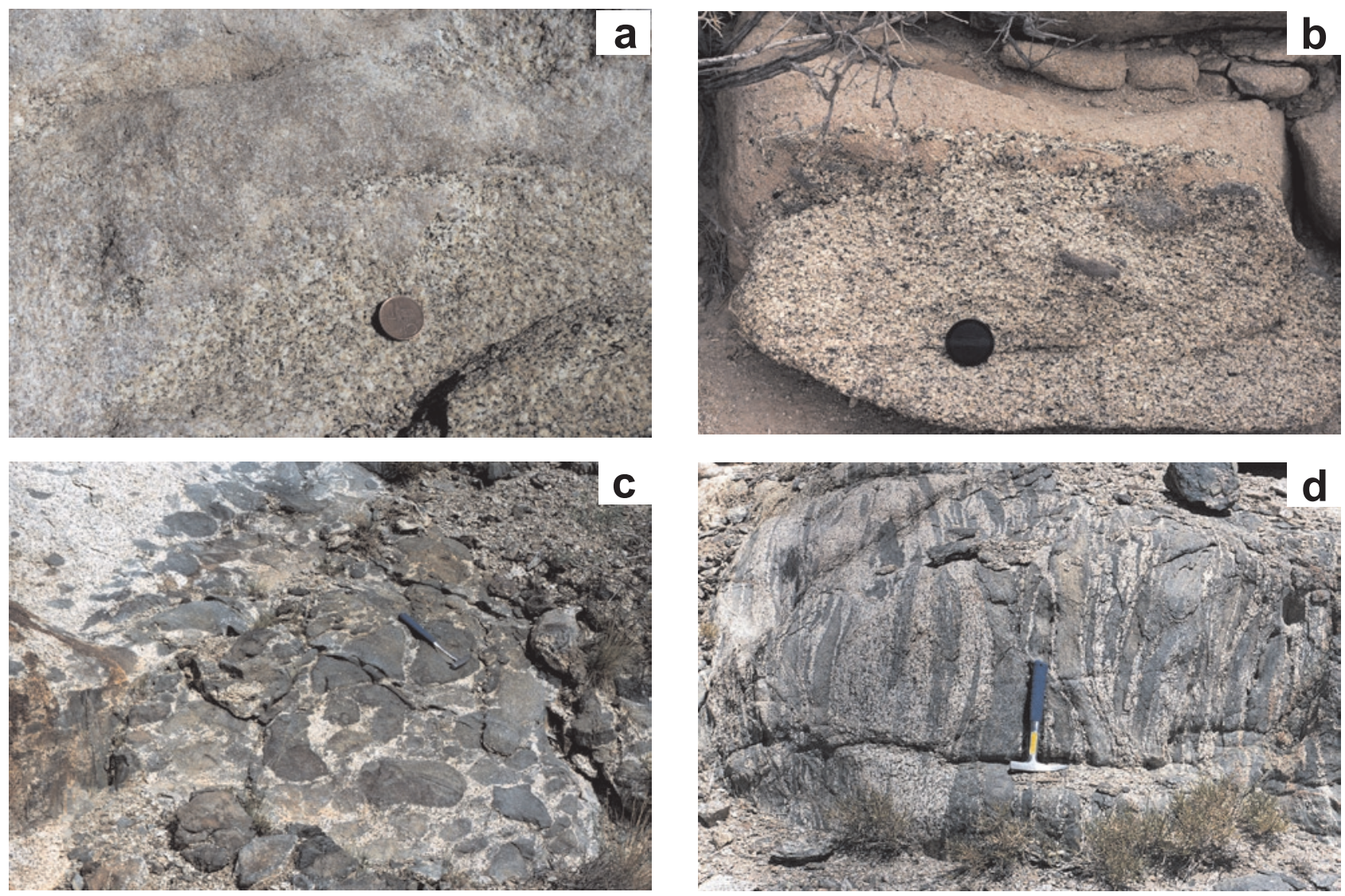

Fig. 5 Field photographs documenting magma interaction processes in the Zamyn Belgekh Pluton: a, b - lobate contacts between granites and granodiorites; $\mathbf{c}$ - swarm of mafic microgranular enclaves of dioritic composition in granodiorite; $\mathbf{d}$ - strongly deformed mafic enclaves near the northern margin of the pluton.

and granites and granodiorites attain even an orthogneiss appearance.

Subvolcanic dykes commonly accompany rocks of the Gobi Tien Shan Intrusive Complex and occur also in other Paleozoic units. Subvertical dykes of subvolcanic character, reaching a thickness of first meters and a length of up to $15 \mathrm{~km}$, strike in two dominant W-E and WNW-ESE directions. They can be subdivided into basic (predominantly basaltic), and intermediate to acid porphyries. Contacts between the dykes and host rocks are usually sharp.

\subsubsection{Petrography of the main rock types in the Gobi Tien Shan Intrusive Complex}

Biotite (leuco-) granite to granodiorite is a mediumto coarse-grained, light grey to light red or pink rock with hypautomorphic granular texture. It is composed of quartz (15-45\%), K-feldspar (15-54\%), plagioclase $(20-50 \%)$ and biotite $(0-7 \%)$; hornblende is exceptional. The feldspars are usually tabular, in some of the samples of hypersolvus character. Tabular subhedral K-feldspars are perthitic, often showing Carlsbad twinning. Up to 2 $\mathrm{cm}$ large subhedral phenocrysts of poikilitic and perthitic $\mathrm{K}$-feldspars were observed in porphyritic varieties. The slightly sericitized plagioclases of oligoclase composition are polysynthetically twinned or oscillatory-zoned. Quartz is anhedral with undulatory extinction. Myrmekites are frequent. Biotite is brown, slightly pleochroic. Zircon, monazite, apatite, opaque mineral, exceptionally allanite and titanite appear as accessories. Secondary minerals are chlorite, epidote, leucoxene and sericite. Biotite granite to granodiorite occurs particularly in the south-eastern part of the Zamyn Belgekh Pluton and forms smaller bodies inside the massif.

Granophyric leucocratic granites are light grey, reddish, fine- to medium-grained rocks. Granophyric granites occur together with common biotite granites. They are composed of quartz (20-40\%), K-feldspar (22-55\%), plagioclase (12-45\%) and biotite (1-10\%); muscovite is rare and hornblende exceptional. They are characterized by mutual graphic intergrowths of quartz and $\mathrm{K}$-feldspar forming granophyric, micrographic or 
aplitic structures. K-feldspars are often strongly perthitic. The polysynthetically twinned plagioclase corresponds to oligoclase, locally indistinctly zoned and slightly altered in the core. In some of the samples, plagioclase crystals up to $3 \mathrm{~mm}$ in size form interconnected framework, their interstices being filled by the granophyric quartz-K-feldspar intergrowths (Fig. 4e). In the types transitional to the subvolcanic rocks, feldspars or, more rarely, quartz, form cores of granophyric intergrowths (Fig. 4f). Zircon, monazite, apatite, opaque mineral, and exceptionally allanite and titanite appear as accessories. Secondary minerals are chlorite, epidote, leucoxene, sericite, and rarely carbonate.

Hornblende-biotite to biotite-hornblende granodiorite to tonalite is a medium-grained, exceptionally even a coarse-grained rock. It is the prevailing type in the Gobi Tien Shan Intrusive Complex and always contains enclaves of melanocratic biotite-hornblende diorites. Phenomena indicative of magma mixing and fluidal textures are characteristic. This rock type is composed of quartz (11-45\%), plagioclase (24-65\%), K-feldspar (0-26\%), biotite $(0-20 \%)$, and amphibole (0-14\%). Structure is subautomorphic, granular. The plagioclases of oligoclase to andesine composition are tabular, rarely even euhedral, polysynthetically lamellar and also normally zoned. Basic cores are intensively saussuritized and sericitized. K-feldspars are of irregular shape, poikilitic and perthitic. Quartz is anhedral with undulatory extinction. Biotite is brown, strongly pleochroic. Amphibole forms thick columnar, subhedral to euhedral grains of green-brown colour. Acicular and oval apatite, zircon, abundant titanite and an opaque mineral appear as accessories. Dark minerals are often altered to a mixture of chlorite, opaque and epidotegroups minerals; titanite is altered to leucoxene.

Biotite-hornblende diorite to quartz diorite forms enclaves in granodiorites and also individual bodies. The largest of them are situated in the eastern and western parts of the Zamyn Belgekh Pluton. The diorites are medium- to coarse-grained, grey to dark grey rocks with hypautomorphic granular structure. The tabular minerals in the rock are usually oriented in magmatic foliation. Diorites consist of quartz (0-15\%), plagioclase (44-62\%), K-feldspar (0-20\%), biotite (0-18\%), and amphibole (3-43\%). The main mineral is a polysynthetically lamellar or, more often, oscillatory zoned plagioclase of andesine composition. The plagioclases are intensively saussuritized and sericitized. $\mathrm{K}$-feldspar, if present, is anhedral. Euhedral, poikilitic amphibole is thickly columnar, enclosing elongated plagioclase grains. It usually predominates over brown biotite. In one of the microdiorite samples, pyroxene was identified. A very common accessory is titanite, other include apatite, zircon and opaque minerals. The rocks are commonly epidotized and chloritized.
Gabbro to gabbrodiorite forms part of the mafic enclaves in granodiorites and is exposed in small massifs bound to the W and NW margins of the Zamyn Belgekh Pluton and also a body south of the Tsagaan Bogd. It is a dark grey to green-grey, medium- to coarse-grained rock. Texture is ophitic with preferred orientation of plagioclase laths. It is composed of plagioclase (38-56 \%), olivine (0-25\%), pyroxene (9-31\%), biotite (0-14\%) and amphibole (5-8\%). Plagioclases of andesine-labradorite composition are saussuritized. The pyroxenes are often rimmed by hornblende and biotite and/or almost completely replaced by these minerals. Olivine grains are serpentinized. Hornblende is light green-brown and altered to actinolite. Magnetite and ilmenite occur subordinately in many gabbros and melanocratic diorites. Subhedral apatite grains are accessoric.

\subsection{Naran Sevest Massif}

The Naran Sevest Massif is exposed on highly weathered outcrops and eluvia in the SW part of Gobi Tien Shan Domain SE of Talyn Meltes bulag near the Chinese border. Its age was considered to be the Early Devonian by Ruzhentsev (1985), who described Lower Devonian conglomerates transgressively overlying the plutonic rock and having tectonic contacts with the Ordovician/Silurian volcanosedimentary rocks. The massif is built by grey medium-grained hornblende-biotite granodiorites to diorites with composition corresponding to rocks of the Gobi Tien Shan Intrusive Complex. They are often altered and mylonitized. They are composed generally of intensely sericitized, oscillatorilly zoned plagioclase of andesine composition in its core, kaolinized K-feldspar, chloritized biotite flakes, pseudomorphs of chlorite and carbonate probably after hornblende and anhedral quartz. Numerous enclaves of dioritic and gabbroic rocks have been recorded.

\subsection{Tsagaan Bogd Massif}

The Tsagaan Bogd Massif is restricted to a narrow, E-W elongated body in the vicinity of the Tsagaan Bogd Mt. It consists of brownish red to brownish yellow alkali-feldspar granite and biotite granite, with a distinctly developed porphyritic texture. According to Filippova (1990a) it is comagmatic with the Middle-Upper Carboniferous rhyolites. Among the felsic minerals in the granites, K-feldspar (25-35\%) dominates over quartz and oligoclase. K-feldspar phenocrysts are up to $1 \mathrm{~cm}$ across and are intensively haematitized. The content of biotite reaches $15 \%$, the mineral being intensively chloritized. In terms of their petrology, the rocks of the massif can be related to the acid members of the Gobi Tien Shan Intrusive Complex. 


\section{Geochemistry}

The presented analytical data represent available lithogeochemical samples collected during the geological survey of Trans-Altay Gobi (Šourek et al. 2003). The list of samples is provided in Tab. 3 . Analytical results are shown in Tables 4 and 5.

\subsection{Bayan Ayrag Massif}

Only major-element data are available from this massif. Classification in the $\mathrm{Q}^{\prime}-\mathrm{ANOR}$ diagram (Streckeisen and Le Maitre 1979) shows in accordance with petrographical data large compositional variation spanning from granite to quartz monzonite, quartz monzogabbro and tonalite (Fig. 3). The rocks belong to the high-K calc-alkaline series of Peccerillo and Taylor (1976) (Fig. 6b) with $\mathrm{SiO}_{2}$ abundances ranging between 56 and 69 wt. \%. The potassium contents are high (2.3-5.6 wt. $\left.\% \mathrm{~K}_{2} \mathrm{O}\right)$ and the $\mathrm{K}_{2} \mathrm{O} / \mathrm{Na}_{2} \mathrm{O}$ ratios low (0.6-0.9). The rocks are distinctly metaluminous with the values for the Shand's alumina saturation index (A/CNK, Shand 1947) ranging between 0.75 and 1.00 (Fig. 6c).

\subsection{Trans-Altay Intrusive Complex}

Rocks of the Trans-Altay Intrusive Complex can be classified as alkali feldspar granite, granite, quartz monzonite and quartz monzodiorite on the basis of the $\mathrm{Q}^{\prime}-\mathrm{ANOR}$ diagram (Fig. 3). Silica abundances range between 60 and $76 \mathrm{wt}$. \%. They are calc-alkaline and belong to the high-K series (Peccerillo and Taylor 1976) with alkaline affinity of some samples. Two suites with different trends can be distinguished in the $\mathrm{SiO}_{2}-\mathrm{K}_{2} \mathrm{O}$ diagram (Fig. 6b), but other petrochemical parameters do not corroborate those trends. The $\mathrm{K}_{2} \mathrm{O} / \mathrm{Na}_{2} \mathrm{O}$ ratio is very variable with the median close to 1 . Metaluminous rocks dominate $(\mathrm{A} / \mathrm{CNK}=0.8-1.0)$. The $\mathrm{K} / \mathrm{Rb}$ ratios vary between c. 300 and 800, samples from the Gobi Tien Shan Domain showing values below 250. The $\mathrm{Rb} / \mathrm{Sr}$ ratios (Fig. $7 b$ ) are usually below 0.6 except for two samples of cataclased rocks reaching $\mathrm{Rb} / \mathrm{Sr}$ of 5. The NMORB-normalized spider plots (Fig. 8) display a marked depletion in $\mathrm{Nb}, \mathrm{P}$, Ti, while LILE are enriched. The $\mathrm{Ba}$ and $\mathrm{Sr}$ are generally slightly enriched but are distinctly depleted in two samples. Chondrite-normalized (Boynton 1984) REE patterns (Fig. 9) show a good fractionation of LREE, while HREE trends are flat $\left(\mathrm{La}_{\mathrm{N}} / \mathrm{Yb}_{\mathrm{N}}=4.5-14.2 ; \mathrm{La}_{\mathrm{N}} / \mathrm{Sm}_{\mathrm{N}}=\right.$ $\left.2.6-6.2, \mathrm{Gd}_{\mathrm{N}} / \mathrm{Yb}_{\mathrm{N}}=0.8-2.0\right)$. Negative Eu anomaly is
Tab. 3 List of analysed samples. Explanations: BA - Bayan Ayrag Massif; GBR - gabbro massifs; GTS - Gobi Tien Shan Intrusive Complex; GV Gurvan Khar Massif; IB - Ikh Bayan Massif; TA - Trans-Altay Intrusive Complex; TSB - Tsagaan Bogd Massif.

\begin{tabular}{|c|c|c|c|c|c|}
\hline No. & Ref. Point & Rock & Unit & $\mathbf{E}\left({ }^{\circ}\right)$ & $\mathbf{N}\left({ }^{\circ}\right)$ \\
\hline 1 & $5-1019$ & Bt Hbl monzonite & BA & 98.3561 & 43.9694 \\
\hline 2 & $5-1070$ & Hbl Bt quartz monzonite & BA & 98.489 & 43.9961 \\
\hline 3 & $5-1074$ & $\mathrm{Bt} \mathrm{Hbl}$ granodiorite & $\mathrm{BA}$ & 98.4089 & 43.9829 \\
\hline 4 & $5-1075$ & Monzodiorite & BA & 98.3649 & 43.9991 \\
\hline 5 & $15-1250$ & Gabbro & GBR & 97.2146 & 43.6572 \\
\hline 6 & $15-1287$ & Gabbro & GBR & 97.4590 & 43.5636 \\
\hline 7 & $3-1035$ & Gabbro & GBR & 97.2115 & 43.7299 \\
\hline 8 & $3-1083$ & Gabbro & GBR & 97.0202 & 43.9225 \\
\hline 9 & $3-1096$ & Gabbro & GBR & 97.2342 & 43.6873 \\
\hline 10 & $3-1113$ & Gabbro & GBR & 97.1976 & 43.8619 \\
\hline 11 & $14-1235 \mathrm{~A}$ & Metagranite & GTS & 96.5592 & 43.3475 \\
\hline 12 & $17-1142$ & Porphyritic granite & GTS & 97.7668 & 43.7203 \\
\hline 13 & $27-1225$ & Bt granodiorite & GTS & 97.2935 & 43.0514 \\
\hline 14 & $27-1226$ & Granite & GTS & 97.4532 & 43.0788 \\
\hline 15 & $27-1230 \mathrm{~B}$ & Granite & GTS & 97.3441 & 43.0698 \\
\hline 16 & $27-1240$ & Granite & GTS & 97.1927 & 43.0303 \\
\hline 17 & $28-5298$ & Bt Hbl quartz monzonite & GTS & 97.6260 & 43.2237 \\
\hline 18 & $28-5301$ & Bt $\mathrm{Hbl}$ granodiorite & GTS & 97.6402 & 43.2262 \\
\hline 19 & $28-5333 a$ & Bt Hbl monzonite & GTS & 97.5767 & 43.2821 \\
\hline 20 & $40-1010 b$ & Granite & GTS & 97.8495 & 42.9439 \\
\hline 21 & $40-1061$ & Granite & GTS & 97.5310 & 42.9587 \\
\hline 22 & $40-1062 b$ & Granite & GTS & 97.5063 & 42.9574 \\
\hline 23 & 41-1002 & Hbl Bt granodiorite & GTS & 98.4867 & 42.8127 \\
\hline 24 & $41-1007 \mathrm{~A}$ & Monzonite & GTS & 98.4385 & 42.7289 \\
\hline 25 & $41-1025$ & $\mathrm{Bt} \mathrm{Hbl}$ granodiorite & GTS & 98.3187 & 42.8832 \\
\hline 26 & 41-1062 & Gabbro & GTS & 98.0794 & 42.9323 \\
\hline 27 & $42-1004$ & Granite & GTS & 98.6896 & 42.9557 \\
\hline 28 & $42-1098$ & $\mathrm{Hbl}$ diorite & GTS & 98.8649 & 42.8966 \\
\hline 29 & $42-1121$ & Granite & GTS & 98.8159 & 42.7642 \\
\hline 30 & 42-P59B & Granite & GTS & 98.6485 & 42.8985 \\
\hline 31 & $15-1247$ & Bt metagranodiorite & GV & 97.1337 & 43.6428 \\
\hline 32 & $15-1248$ & Bt porphyric granite & GV & 97.1484 & 43.6497 \\
\hline 33 & $15-1254$ & Bt metagranite & GV & 97.1902 & 43.6196 \\
\hline 34 & $2-1054$ & Hbl diorite & GV & 96.5039 & 43.8736 \\
\hline 35 & $3-1060$ & Bt $\mathrm{Hbl}$ diorite & GV & 97.2556 & 43.6899 \\
\hline 36 & $1-1071 \mathrm{a}$ & Bt porphyric granite & IB & 96.1118 & 43.9546 \\
\hline 37 & $15-1202 \mathrm{~A}$ & Bt granite & IB & 97.4699 & 43.5861 \\
\hline 38 & $3-1052$ & Bt granite & IB & 97.4487 & 43.6998 \\
\hline 39 & $4-1036 \mathrm{~A}$ & Bt granite $( \pm \mathrm{Hbl})$ & IB & 97.5206 & 43.6759 \\
\hline 40 & 4-1038 & Porphyric granite & IB & 97.5045 & 43.6951 \\
\hline 41 & $1 \_2200$ & Bt porpyric granite & TA & 96.4608 & 43.7828 \\
\hline 42 & 1_2237 & Bt granite & TA & 96.4858 & 43.8713 \\
\hline 43 & $13-1027$ & Hbl Bt quartz monzonite & TA & 96.4544 & 43.4772 \\
\hline 44 & $14-1203$ & Bt porpyritic granite & TA & 96.5933 & 43.4673 \\
\hline 45 & $14-1205$ & $\mathrm{Hbl} \mathrm{Bt} \mathrm{granite}$ & TA & 96.5048 & 43.4996 \\
\hline 46 & $15-1208$ & Bt quartz monzonite & TA & 97.3509 & 43.4529 \\
\hline 47 & $15-1224$ & Bt granophyric granite & TA & 97.0650 & 43.4745 \\
\hline 48 & $15-1293$ & Bt Hbl quartz monzonite & TA & 97.3584 & 43.5902 \\
\hline 49 & $2-1017$ & Bt granite & TA & 96.9018 & 43.9218 \\
\hline 50 & $28-5335$ & Porphyritic granite & TA & 97.5839 & 43.3033 \\
\hline 51 & $3-1064$ & Hbl monzonite & TA & 97.2139 & 43.7962 \\
\hline 52 & $3-1068$ & Hbl quartz monzonite & TA & 97.3088 & 43.8739 \\
\hline 53 & $3-1079 a$ & Hbl quartz monzonite & TA & 97.1426 & 43.9559 \\
\hline 54 & $3-1112$ & Hbl quartz monzonite & TA & 97.1503 & 43.8451 \\
\hline 55 & $3-1150$ & Granite & TA & 97.0702 & 43.7097 \\
\hline 56 & $42-1104$ & Bt granite & TA & 98.9563 & 42.9396 \\
\hline 57 & $42-1019$ & Leucogranite & TSB & 98.6501 & 42.8693 \\
\hline
\end{tabular}


Tab. 4 Major-element analyses (wt. \%).

\begin{tabular}{|c|c|c|c|c|c|c|c|c|c|c|c|c|c|c|c|c|c|c|c|}
\hline \multirow[b]{2}{*}{ Sample } & \multicolumn{4}{|c|}{ Bayan Ayrag } & \multicolumn{6}{|c|}{ Gabbro } & \multicolumn{9}{|c|}{ Gobi Tien Shan } \\
\hline & 1 & 2 & 3 & 4 & 5 & 6 & 7 & 8 & 9 & 10 & 11 & 12 & 13 & 14 & 15 & 16 & 17 & 18 & 19 \\
\hline $\mathrm{SiO}_{2}$ & 9.09 & 68.22 & 68.50 & 56.28 & 46.95 & 50.49 & 49.45 & 48.94 & 47.78 & 44.72 & 75.92 & 75.68 & 68.57 & 72.32 & 75.29 & 76.95 & 64.72 & 63.27 & 59.09 \\
\hline $\mathrm{TiO}_{2}$ & 0.90 & 0.40 & 0.77 & 0.91 & 1.05 & 0.76 & 0.29 & 1.14 & 0.13 & 2.70 & 0.16 & 0.19 & 0.49 & 0.22 & 0.15 & 0.14 & 0.60 & 0.63 & 0.94 \\
\hline $\mathrm{Al}_{2} \mathrm{O}_{3}$ & 16.95 & 14.48 & 14.16 & 15.89 & 14.41 & 19.41 & 14.52 & 19.62 & 23.71 & 16.74 & 12.59 & 12.91 & 14.82 & 14.28 & 12.09 & 12.11 & 16.12 & 16.99 & 18.32 \\
\hline $\mathrm{Fe}_{2} \mathrm{O}_{3}$ & 3.83 & 2.25 & 1.40 & 4.91 & 11.47 & 8.35 & 9.35 & 9.67 & 4.23 & 14.83 & 1.56 & 1.95 & 3.48 & 2.60 & 1.85 & 1.24 & 4.66 & 4.88 & 6.14 \\
\hline $\mathrm{FeO}$ & 90 & 1.26 & 3.67 & 3.74 & n.d. & n.d. & n.d. & n.d. & n.d. & n.d. & n.d. & d. & n.d. & n.d. & n.d. & n.d. & n.d. & n.d. & n.d. \\
\hline $\mathrm{MnO}$ & & 0.15 & 0.13 & 0.21 & 0.15 & 0.11 & 0.14 & 0.16 & 0.06 & 0.19 & 03 & & 0.08 & 0.06 & 0.04 & 0.03 & 09 & 08 & 10 \\
\hline & 60 & 0.83 & 1.22 & 4.18 & 13.91 & 4.81 & 14.79 & 3.27 & 7.26 & & & & & 0.47 & 0.19 & 0.14 & 1.22 & 1.42 & 1.84 \\
\hline $\mathrm{CaO}$ & 33 & 2.50 & 2.86 & 6.80 & 6.84 & 9.93 & 7.27 & 10.26 & 11.40 & & & & 2.93 & 2.14 & 0.71 & 0.63 & 3.17 & 4.21 & 5.01 \\
\hline $\mathrm{Na}_{2} \mathrm{O}$ & 83 & 4.43 & 3.76 & 3.58 & 2.74 & 2.96 & 1.98 & 3.47 & 2.65 & 3.76 & 3.64 & 3.89 & 4.36 & 4.08 & 3.34 & 3.34 & 5.33 & 14 & 5.26 \\
\hline $\mathrm{K}_{2} \mathrm{O}$ & 21 & 4.09 & 2.28 & 2.49 & 0.66 & 0.81 & 0.11 & 0.75 & 0.19 & 0.57 & 4.87 & 3.41 & 2.96 & 2.73 & 4.67 & 5.14 & 03 & 82 & 1.55 \\
\hline $\mathrm{P}_{2} \mathrm{O}_{5}$ & 34 & 0.17 & 0.14 & 0.31 & 0.25 & 0.13 & 0.03 & 0.43 & 0.03 & 0.94 & 0.02 & 0.03 & 0.10 & 0.03 & n.d. & 0.03 & 0.18 & 0.18 & 0.23 \\
\hline $\mathrm{Cr}_{2} \mathrm{O}_{3}$ & n.d. & n.d. & n.d. & n.d. & 0.08 & 0.01 & 0.10 & 0.01 & 0.04 & 0.01 & & & & n.d. & n.d. & n.d. & n.d. & n.d. & n.d. \\
\hline LOI & 153 & 0.80 & 1.25 & 1.38 & 0.60 & 1.50 & 1.30 & 1.60 & 1.90 & 0.30 & & & 0.40 & 0.60 & 0.40 & 0.20 & 0.90 & 1.00 & 1.20 \\
\hline $40-$ & & 0.05 & 0.10 & 0.08 & & & & & & & & & & n.d. & n.d. & n.d. & & d. & n.d. \\
\hline & $d$ & n.d. & n.d. & & 0.04 & & & 0.03 & & 0.02 & & & 0.04 & 0.04 & 0.05 & 0.06 & 04 & 88 & 04 \\
\hline $\mathrm{TOT} / \mathrm{s}$ & n.d. & n.d. & n.d. & n.d. & 0.17 & 0.01 & 0.20 & 0.02 & 0.06 & 0.16 & n.d. & 0.01 & n.d. & 0.02 & 0.01 & n.d. & 0.01 & 0.01 & 0.02 \\
\hline & 8.75 & 98.83 & 98.99 & 99.38 & 99.17 & 99.31 & 99.39 & 99.38 & 99.42 & 99.42 & 100.20 & 100.07 & 99.31 & 99.60 & 98.77 & 99.97 & 99.11 & 99.72 & 99.74 \\
\hline & & 1.24 & 1.64 & & & & & & & & & & & & & 0 & & 3 & 77 \\
\hline $\mathrm{A} / \mathrm{CNK}$ & 91 & 0.89 & 1.02 & 0.76 & 0.82 & 0.82 & 0.87 & 0.78 & 0.94 & 0 & 1 & 1 & 0.94 & 1.05 & 1.02 & 0.99 & .96 & 94 & 0.94 \\
\hline \multirow[t]{2}{*}{$\mathrm{K}_{2} \mathrm{O} / \mathrm{Na}_{2} \mathrm{O}$} & 84 & 92 & 0.61 & 070 & 0.24 & 0.27 & 0.06 & 022 & 007 & 015 & 134 & 088 & 0.68 & 0.67 & 1.40 & 1.54 & .38 & 35 & 0.29 \\
\hline & \multicolumn{11}{|c|}{ Gobi Tien Shan } & \multicolumn{5}{|c|}{ Gurvan Khar } & \multicolumn{3}{|c|}{ Ikch Bayan } \\
\hline & & . & 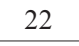 & 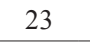 & & & 26 & - & & & & & & & 34 & & & & 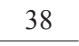 \\
\hline $\mathrm{SiO}_{2}$ & 75.40 & 71.33 & 72.52 & 65 & 57 & 61 & 46 & 75 & 53 & 75 & 74.14 & 67 & 71.07 & 70.51 & 60.19 & 57.16 & 72.91 & 72.98 & 75.16 \\
\hline $\mathrm{TiO}_{2}$ & 0.25 & 0.32 & 0.25 & 0.64 & 1.10 & 0.74 & 3.27 & 0.23 & 1.36 & 0.05 & 0.29 & 0.31 & 0.18 & 0.17 & 0.47 & .76 & 22 & 16 & 0.13 \\
\hline $\mathrm{O}_{3}$ & 12.17 & 14.57 & 13.83 & 14.96 & 16.11 & 15.94 & 17.39 & 12.46 & 17.06 & 14.16 & 12.61 & 16.79 & 15.93 & 16.00 & 17.17 & 18.35 & 13.35 & 13.95 & 13.11 \\
\hline $\mathrm{Fe}_{2} \mathrm{O}_{3}$ & 1.60 & 2.46 & 2.14 & 5.88 & 7.66 & 5.24 & 12.03 & 1.90 & 8.18 & 1.08 & 2.10 & 2.94 & 1.89 & 1.80 & 6.02 & 6.26 & 2.15 & 2.18 & 1.57 \\
\hline & & & & & & & & & & & & & & n.d. & d. & d. & d. & l.d. & n.d. \\
\hline & & & & & & & & & & & & & & & & & 0.04 & 03 & 0.03 \\
\hline & & & & & & & 4.60 & & & & & & & 0.48 & 2.59 & 2.54 & 0.44 & .25 & 0.27 \\
\hline $\mathrm{CaO}$ & & 2.18 & 1.68 & 3.68 & 4.03 & 5.02 & 9.85 & 0.96 & 8.54 & 0.65 & 8 & & 3.17 & 3.01 & 6.31 & 7.02 & 41 & 02 & 27 \\
\hline $\mathrm{Na}_{2} \mathrm{O}$ & & 4.20 & 3.76 & 3.53 & 4.56 & 4.04 & 2.80 & 3.54 & 3.24 & 4.25 & 3.47 & 5.12 & 5.05 & 5.33 & 3.48 & 4.68 & 3.73 & 4.37 & 3.48 \\
\hline $\mathrm{K}_{2} \mathrm{O}$ & .03 & 2.63 & 3.58 & 2.71 & 1.74 & 2.06 & 0.67 & 4.53 & 1.24 & 3.17 & 4.20 & 1.02 & 1.18 & 1.19 & 1.35 & 0.60 & 4.12 & 4.11 & 4.32 \\
\hline $\mathrm{P}_{2} \mathrm{O}_{5}$ & 0.05 & 0.07 & 0.04 & 0.18 & 0.34 & 0.16 & 0.03 & 0.03 & 0.31 & 0.04 & 0.04 & 0.11 & 0.05 & 0.07 & 0.15 & 0.31 & 0.05 & 0.03 & 0.05 \\
\hline & & n.d. & n.d. & 0.00 & n.d. & 0.00 & n.d. & n.d. & 0.02 & & n.d. & 0.00 & n.d. & 0.00 & 0.01 & 0.00 & 0.00 & 0.00 & 0.00 \\
\hline LOI & 1.70 & 1.30 & 1.20 & 1.40 & 2.60 & 1.60 & 2.90 & 1.00 & 1.90 & 0.80 & 0.70 & 0.70 & 0.40 & 0.60 & 1.50 & 1.60 & 0.70 & 0.60 & 0.70 \\
\hline & & n.d. & n.d. & n.d. & n.d. & n.d. & n.d. & n.d. & & & & & n.d. & n.d. & n.d. & n.d. & n.d. & d. & n.d. \\
\hline & & 0.02 & 0.06 & & 0.01 & 0.06 & & 0.04 & & & & & 0.04 & 0.04 & 0.03 & 0.03 & 0.03 & 0.03 & 0.04 \\
\hline $\mathrm{TOT} / \mathrm{S}$ & 0.05 & 0.01 & 0.01 & 0.02 & 0.01 & 0.01 & 0.15 & n.d. & 0.01 & 0.01 & 0.01 & n.d. & 0.02 & 0.01 & 0.01 & 0.02 & 0.01 & n.d. & 0.01 \\
\hline Total & 99.781 & 100.15 & 99.61 & 99.971 & 100.08 & 99.37 & 100.09 & 100.48 & 100.12 & 99.97 & 99.30 & 99.79 & 99.55 & 99.26 & 99.39 & 99.43 & 99.19 & 99.78 & 100.17 \\
\hline $\mathrm{A} / \mathrm{NK}$ & & 1.49 & 1.37 & 1.71 & 1.72 & 1.80 & 3.26 & & & & & & 1.66 & 1.59 & 2.39 & 2.20 & 1.26 & 1.20 & 1.26 \\
\hline $\mathrm{A} / \mathrm{CNK}$ & 1.04 & 1.06 & 1.05 & 0.97 & 0.90 & 0.89 & 0.75 & 1.00 & 0.77 & 1.22 & 1.02 & 0.99 & 1.04 & 1.03 & 0.92 & 0.87 & 1.01 & 1.03 & 1.03 \\
\hline $\mathrm{K}_{2} \mathrm{O} / \mathrm{Na}_{2} \mathrm{O}$ & 1.07 & 0.63 & 0.95 & 0.77 & 0.38 & 0.51 & 0.24 & 1.28 & 0.38 & 0.75 & 1.21 & 0.20 & 0.23 & 0.22 & 0.39 & 0.13 & 1.10 & 0.94 & 1.24 \\
\hline
\end{tabular}

pronounced and its magnitude generally increasing with $\mathrm{SiO}_{2}\left(\mathrm{Eu} / \mathrm{Eu}^{*}=0.8-0.1\right)$. The rare values exceeding 1 in acid to intermediate rock samples can be associated with later alteration of the rocks.

\subsection{Ikh Bayan Massif}

Granites of this massif are chemically homogenous. Samples fall into granite field in the $Q^{\prime}-A N O R$ clas- 
Tab. 4 Major-element analyses (wt. \%) continued.

\begin{tabular}{|c|c|c|c|c|c|c|c|c|c|c|c|c|c|c|c|c|c|c|c|}
\hline \multirow[b]{2}{*}{ Sample } & \multicolumn{2}{|c|}{ Ikch Bayan } & \multicolumn{16}{|c|}{ Trans-Altay } & \multirow{2}{*}{$\frac{\text { TSB }}{57}$} \\
\hline & 39 & 40 & 41 & 42 & 43 & 44 & 45 & 46 & 47 & 48 & 49 & 50 & 51 & 32 & 53 & 54 & 55 & 56 & \\
\hline $\mathrm{SiO}_{2}$ & 70.93 & 71.41 & 73.83 & 75.83 & 66.75 & 74.74 & 69.61 & 68.68 & 68.94 & 64.98 & 70.29 & 68.71 & 60.24 & 61.99 & 63.17 & 63.51 & 75.93 & 68.61 & 78.63 \\
\hline $\mathrm{TiO}_{2}$ & 0.35 & 0.25 & 0.19 & 0.10 & 0.56 & 0.23 & 0.46 & 0.56 & 0.52 & 0.95 & 0.42 & 0.57 & 1.04 & 0.61 & 0.55 & 0.66 & 0.13 & 0.38 & 0.09 \\
\hline $\mathrm{Al}_{2} \mathrm{O}_{3}$ & 14.45 & 14.38 & 13.37 & 12.34 & 14.89 & 12.42 & 14.44 & 15.12 & 14.79 & 16.99 & 14.10 & 14.30 & 16.09 & 16.98 & 15.13 & 16.29 & 12.23 & 13.53 & 11.10 \\
\hline $\mathrm{Fe}_{2} \mathrm{O}_{3}$ & 2.79 & 2.24 & 1.62 & 1.31 & 2.45 & 1.56 & 3.03 & 3.31 & 3.13 & 4.43 & 2.52 & 3.97 & 6.60 & 4.19 & 4.71 & 4.59 & 2.15 & 2.40 & 0.63 \\
\hline & n.d. & n.d. & n.d. & & n.d. & & & & & & & & & & d. & n.d. & n.d. & d. & n.d. \\
\hline $\mathrm{MnO}$ & 0.07 & 0.05 & 0.04 & 02 & 0.03 & 0.01 & 0.05 & 0.07 & 0.07 & 0.08 & 0.03 & 0.04 & 0.11 & 0.09 & 0.06 & 0.06 & 05 & 0.03 & 0.01 \\
\hline & & 63 & & & 61 & .46 & & & & & & & & & 2.07 & 1.91 & 04 & 62 & 0.09 \\
\hline & & 2 & & & & & & & & & & & & & & 3.06 & 36 & 36 & 0.42 \\
\hline $\mathrm{Na}_{2} \mathrm{O}$ & 40 & .88 & 7 & 3.16 & 4.48 & 2.77 & & & 5.02 & 5.36 & & & & & & 4.59 & 4.12 & 3.79 & 2.94 \\
\hline $\mathrm{K}_{2} \mathrm{O}$ & 04 & .58 & 5.16 & 4.96 & 3.29 & 5.64 & 4.11 & 3.40 & 3.41 & 3.01 & & 7 & 2.72 & & 3.32 & 3.50 & 4.68 & 200 & 4.84 \\
\hline $\mathrm{P}_{2} \mathrm{O}_{5}$ & 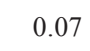 & 0.09 & 0.04 & 0.02 & 0.19 & 0.07 & 0.11 & 0.11 & 0 . & 0.15 & 0 & 5 & 0.32 & . & 0.26 & 0.24 & n.d. & 0.11 & 1.d. \\
\hline $\mathrm{Cr}_{2} \mathrm{O}_{3}$ & 0.00 & 0.00 & 0.01 & 0.01 & 0.01 & 0.01 & 0.01 & n.d. & n.d. & 0.00 & 0.00 & 0.00 & n.d. & 0.00 & 0.01 & 0.01 & n.d. & n.d. & n.d. \\
\hline LOI & 0.90 & 0.70 & 0.50 & 0.40 & 0.60 & 0.70 & 0.20 & 0.40 & 0.50 & 0.40 & 0.70 & 1.10 & 1.10 & 1.70 & 2.70 & 1.20 & 0.30 & 3.20 & 0.50 \\
\hline $\mathrm{H}_{2} \mathrm{O}^{-}$ & n.d. & n.d. & n.d. & n.d. & n.d. & n.d. & n.d. & n.d. & 11 & n. & 1. & d. & n. & . & n.d. & n.d. & n.d. & i.d. & 1.d. \\
\hline & 0.02 & 0.03 & 0.05 & 0.04 & 0.07 & 0.03 & 0.02 & n.d. & 0.02 & 0.01 & 0.07 & 0.07 & 0.03 & & 0.34 & 0.04 & 0.03 & 0.49 & 0.04 \\
\hline $\mathrm{TOT} / \mathrm{S}$ & 0.02 & 0.01 & n.d. & 0.02 & 0.02 & n.d. & n.d. & 0.01 & n.d. & 0.01 & 0.01 & 0.02 & 0.03 & 0.02 & 0.01 & 0.02 & 0.01 & n.d. & 0.03 \\
\hline Total & 100.05 & 99.22 & 99.76 & 99.37 & 99.00 & 99.87 & 99.29 & 99.53 & 99.24 & 100.31 & 99.46 & 99.81 & 99.36 & 99.08 & 99.80 & 99.721 & 100.00 & 99.09 & 99.27 \\
\hline $\mathrm{A} / \mathrm{NK}$ & 1.24 & 1.40 & & 4 & 1.36 & 1.16 & 1.28 & & & 1.4 & 1.14 & 1.38 & & 1.46 & 1.48 & 1.44 & 1.03 & 1.28 & 1.10 \\
\hline $\mathrm{A} / \mathrm{CNK}$ & 1.03 & 1.05 & 0.98 & 1.00 & 0.81 & 0.97 & 0.96 & 0.97 & 0.96 & 0.99 & 0.96 & 1.00 & 0.87 & 0.94 & 0.89 & 0.96 & 0.98 & 0.91 & 1.02 \\
\hline $\mathrm{K}_{2} \mathrm{O} / \mathrm{Na}_{2} \mathrm{O}$ & 0.92 & 0.92 & 1.18 & 1.57 & 0.73 & 2.04 & 0.99 & 0.62 & 0.68 & 0.56 & 1.62 & 1.08 & 0.59 & 0.68 & 0.83 & 0.76 & 1.14 & 1.05 & 1.65 \\
\hline
\end{tabular}

sification (Streckeisen and Le Maitre 1979). They are acid with $\mathrm{SiO}_{2}=71-73$ wt. \%, high-K calc-alkaline and subaluminous (Fig. 6). The $\mathrm{K}_{2} \mathrm{O} / \mathrm{Na}_{2} \mathrm{O}$ ratios fall within the range of $0.9-1.2, \mathrm{~K} / \mathrm{Rb}$ ratios range from 270 to 500 and $\mathrm{Rb} / \mathrm{Sr}$ ratios from 0.4 to 0.7 . They are enriched in LILE in the NMORB-normalized spider plot (Fig. 8); $\mathrm{Nb}, \mathrm{P}$, and $\mathrm{Ti}$ are strongly depleted, while $\mathrm{Pb}$ and $\mathrm{Nd}$ are slightly enriched. The REE patterns (Fig. 9) show slight fractionation of LREE with the HREE trends being flat $\left(\mathrm{La}_{\mathrm{N}} / \mathrm{Yb}_{\mathrm{N}}=5.4-7.6 ; \mathrm{La}_{\mathrm{N}} / \mathrm{Sm}_{\mathrm{N}}=2.9-4.9, \mathrm{Gd}_{\mathrm{N}} / \mathrm{Yb}_{\mathrm{N}}=\right.$ 1.1-1.4). Negative Eu anomaly is well developed (Eu/ $\left.\mathrm{Eu}^{*}=0.3-0.6\right)$.

\subsection{Gurvan Khar Massif}

Samples plotted into the $\mathrm{Q}^{\prime}-\mathrm{ANOR}$ diagram fit the tonalite field, only one corresponds to diorite. They are intermediate to acid $\left(\mathrm{SiO}_{2}=57-71 \mathrm{wt}\right.$. \%) and very low in $\mathrm{K}_{2} \mathrm{O}(0.6-1.4$ wt. \%), corresponding to tholeiite series of Peccerillo and Taylor (1976). The A/CNK values equal 0.9 to 1.0 (Fig. 6). The $\mathrm{K}_{2} \mathrm{O} / \mathrm{Na}_{2} \mathrm{O}$ ratios are low $(0.1-0.4)$. The $\mathrm{K} / \mathrm{Rb}$ ratios are very high (ranging between 430 and 680 ) and $\mathrm{Rb} / \mathrm{Sr}=0.01-0.4$. NMORB normalized spider plot shows distinctive trends. The rocks are strongly enriched in $\mathrm{Ba}$, and $\mathrm{Sr}$, slightly enriched in $\mathrm{U}, \mathrm{Pb}$ and $\mathrm{Nd}$. Niobium only shows marked depletion, while $\mathrm{Rb}, \mathrm{Th}, \mathrm{P}$ and $\mathrm{Ti}$ are depleted slightly. The $\mathrm{Cs}, \mathrm{Pb}$ and $\mathrm{Zr}$ have varied trends (Fig. 8). The REE abundances are very low $(\Sigma R E E=29-56 \mathrm{ppm})$, chondrite-normalized trends showing slight fractionation (Fig. 9), with a weak negative or negligibly positive Eu anomaly $\left(\mathrm{La}_{\mathrm{N}} / \mathrm{Yb}_{\mathrm{N}}=\right.$ 3.3-7.1, $\mathrm{La}_{\mathrm{N}} / \mathrm{Sm}_{\mathrm{N}}=2.1-5.3, \mathrm{Gd}_{\mathrm{N}} / \mathrm{Yb}_{\mathrm{N}}=1.1-1.9, \mathrm{Eu} / \mathrm{Eu}^{*}$ $=0.7-1.1$ ).

\subsection{Gabbroic rocks}

Basic rocks accompanying the Gurvan Khar Massif and the largest body of the Trans-Altay Intrusive Complex could be geochemically classified as gabbro in accordance with the petrography. Silica abundances range between 44 and 50 wt. \%. These are calc-alkaline to tholeiitic rocks except for one sample with alkaline affinity. The $\mathrm{K} / \mathrm{Rb}$ ratios are very high and variable, ranging from 300 to 2000 , with the lowest value in a sample from the GTS. This corresponds well with very low $\mathrm{Rb} / \mathrm{Sr}$ ratios (0.001-0.01), again with the maximum $(0.03)$ in the GTS (Fig. 7b). The NMORB-normalized spider diagrams show high variation in trends (Fig. 10a). Generally, there is only a distinct depletion in $\mathrm{Rb}, \mathrm{Th}$, $\mathrm{Nb}$ and $\mathrm{Zr}$ accompanied by an enrichment in $\mathrm{Ba}$ and $\mathrm{Sr}$. Chondrite-normalized REE patterns reflect differences in the total abundance $(\Sigma \mathrm{REE}=10-160 \mathrm{ppm})$ and variable fractionation $\left(\mathrm{La}_{\mathrm{N}} / \mathrm{Yb}_{\mathrm{N}}=32.4-4.8, \mathrm{La}_{\mathrm{N}} / \mathrm{Sm}_{\mathrm{N}}=1.6-2.7\right.$, $\left.\mathrm{Gd}_{\mathrm{N}} / \mathrm{Yb}_{\mathrm{N}}=1.5-1.9\right)$. Three samples show positive Eu 
Tab. 5 Trace-element analyses (ppm).

\begin{tabular}{|c|c|c|c|c|c|c|c|c|c|c|c|c|c|}
\hline \multirow[b]{2}{*}{ Sample } & \multicolumn{6}{|c|}{ Gabbro massifs } & \multicolumn{7}{|c|}{ Gobi Tien Shan } \\
\hline & 5 & 6 & 7 & 8 & 9 & 10 & 11 & 12 & 13 & 14 & 15 & 16 & 17 \\
\hline $\mathrm{Rb}$ & 8.0 & 16.5 & 0.6 & 12.4 & 2.1 & 2.3 & 162.8 & 84.1 & 120.3 & 92.1 & 156.2 & 176.8 & 44.1 \\
\hline $\mathrm{Cs}$ & 0.4 & 0.7 & n.d. & 0.2 & n.d. & n.d. & 0.9 & 1.9 & 6.5 & 3.1 & 1.9 & 3.1 & 0.8 \\
\hline $\mathrm{Sr}$ & 509.2 & 1145.9 & 520.4 & 802.1 & 889.5 & 968.0 & 48.5 & 163.7 & 271.6 & 229.3 & 90.9 & 41.8 & 409.2 \\
\hline $\mathrm{Ba}$ & 170 & 312 & 74 & 355 & 72 & 331 & 365 & 696 & 465 & 594 & 360 & 205 & 821 \\
\hline $\mathrm{Nb}$ & 3.7 & 1.9 & n.d. & 2.3 & n.d. & 9.2 & 13.2 & 5.0 & 8.0 & 5.6 & 6.2 & 10.3 & 6.3 \\
\hline $\mathrm{Ta}$ & 0.2 & 0.1 & n.d. & 0.2 & n.d. & 0.5 & 1.2 & 0.4 & 0.7 & 0.5 & 0.7 & 1.1 & 0.4 \\
\hline $\mathrm{Zr}$ & 103.8 & 36.9 & 5.5 & 47.9 & 6.6 & 135.1 & 155.3 & 124.3 & 167.2 & 130.7 & 84.0 & 94.1 & 284.6 \\
\hline $\mathrm{Hf}$ & 2.6 & 1.0 & n.d. & 1.5 & n.d. & 3.5 & 5.5 & 3.8 & 5.3 & 4.2 & 3.0 & 3.7 & 7.4 \\
\hline $\mathrm{Ga}$ & 15.2 & 19.9 & 11.3 & 20.8 & 13.1 & 20.7 & 16.9 & 14.6 & 18.0 & 17.4 & 14.2 & 15.6 & 20.0 \\
\hline $\mathrm{Th}$ & 0.4 & 0.8 & n.d. & 1.0 & 0.1 & 0.4 & 22.9 & 8.5 & 13.8 & 8.5 & 16.1 & 19.4 & 4.1 \\
\hline $\mathrm{U}$ & 0.2 & 0.6 & n.d. & 0.4 & n.d. & n.d. & 3.0 & 1.6 & 1.3 & 1.2 & 1.7 & 1.4 & 1.6 \\
\hline $\mathrm{Ni}$ & 303.9 & 39.5 & 239.7 & 6.3 & 210.2 & 74.4 & 3.2 & 1.6 & 4.9 & 6.5 & 5.8 & 5.0 & 4.9 \\
\hline $\mathrm{Co}$ & 73.0 & 31.5 & 66.0 & 22.9 & 30.1 & 49.2 & 1.5 & 1.6 & 5.8 & 3.3 & 2.0 & 1.1 & 6.0 \\
\hline V & 153 & 290 & 82 & 306 & 25 & 334 & 6 & 12 & 58 & 18 & 8 & 5 & 64 \\
\hline $\mathrm{Sc}$ & 18 & 26 & 21 & 33 & 9 & 27 & 4 & 5 & 5 & 4 & 3 & 5 & 11 \\
\hline $\mathrm{Pb}$ & 0.8 & 0.7 & 0.4 & 1.7 & 0.5 & 0.2 & 5.8 & 5.9 & 3.3 & 4.4 & 6.7 & 7.1 & 2.1 \\
\hline $\mathrm{Cu}$ & 98.5 & 60.8 & 153.8 & 118.5 & 95.6 & 89.5 & 5.6 & 1.7 & 6.9 & 9.1 & 10.8 & 7.6 & 8.5 \\
\hline $\mathrm{Zn}$ & 51 & 32 & 22 & 35 & 18 & 53 & 23 & 29 & 27 & 38 & 10 & 12 & 59 \\
\hline $\mathrm{Sn}$ & 1 & 1 & 1 & n.d. & n.d. & 2 & 4 & 1 & 2 & 2 & 1 & 2 & 3 \\
\hline W & 0.1 & 0.7 & n.d. & 0.2 & 0.1 & 0.2 & 0.2 & 0.2 & 1.7 & 0.4 & 0.5 & 0.7 & 0.6 \\
\hline Mo & 0.5 & 0.1 & 0.2 & 0.4 & 0.6 & 0.7 & 0.3 & 0.4 & 0.6 & 0.9 & 1.0 & 0.8 & 0.5 \\
\hline $\mathrm{Cd}$ & n.d. & 0.1 & 0.1 & 0.1 & n.d. & 0.1 & n.d. & n.d. & n.d. & 0.1 & n.d. & 0.1 & n.d. \\
\hline As & 0.9 & 0.5 & n.d. & n.d. & n.d. & n.d. & n.d. & 1.1 & 3.3 & 2.1 & 0.6 & 1.7 & 1.0 \\
\hline $\mathrm{Sb}$ & n.d. & n.d. & n.d. & 0.1 & n.d. & n.d. & n.d. & 0.1 & 0.2 & 0.1 & n.d. & 0.1 & n.d. \\
\hline $\mathrm{Bi}$ & n.d. & n.d. & n.d. & n.d. & n.d. & n.d. & n.d. & n.d. & 0.1 & n.d. & n.d. & 0.1 & 0.1 \\
\hline $\mathrm{Au}(\mathrm{ppb})$ & 0.5 & n.d. & 8.2 & n.d. & n.d. & 0.9 & 0.8 & n.d. & 0.7 & 0.9 & 1.5 & 0.7 & 1.2 \\
\hline $\mathrm{Ag}$ & n.d. & 0.1 & 0.1 & n.d. & n.d. & n.d. & n.d. & n.d. & n.d. & n.d. & n.d. & 0.1 & n.d. \\
\hline $\mathrm{Hg}$ & n.d. & n.d. & n.d. & n.d. & n.d. & n.d. & n.d. & n.d. & n.d. & 0.01 & n.d. & 0.01 & n.d. \\
\hline $\mathrm{Tl}$ & n.d. & n.d. & n.d. & n.d. & n.d. & n.d. & n.d. & n.d. & 0.1 & 0.2 & n.d. & n.d. & n.d. \\
\hline $\mathrm{La}$ & 8.5 & 6.7 & 2.0 & 11.8 & 1.7 & 22.3 & 40.6 & 18.5 & 24.8 & 21.6 & 26.1 & 29.4 & 24.9 \\
\hline $\mathrm{Ce}$ & 21.7 & 15.1 & 3.7 & 26.3 & 3.3 & 54.4 & 79.2 & 33.6 & 58.3 & 46.6 & 53.8 & 64.7 & 53.4 \\
\hline $\operatorname{Pr}$ & 2.95 & 2.04 & 0.49 & 3.68 & 0.45 & 7.88 & 9.11 & 3.78 & 6.40 & 5.03 & 5.65 & 7.13 & 6.56 \\
\hline $\mathrm{Nd}$ & 15.2 & 10.1 & 2.6 & 18.9 & 2.3 & 40.8 & 35.7 & 16.4 & 27.8 & 20.9 & 20.8 & 27.0 & 30.8 \\
\hline $\mathrm{Sm}$ & 3.4 & 2.1 & 0.5 & 4.5 & 0.4 & 8.5 & 7.4 & 3.2 & 5.4 & 3.8 & 3.7 & 4.9 & 6.0 \\
\hline $\mathrm{Eu}$ & 1.06 & 0.70 & 0.36 & 1.48 & 0.38 & 2.47 & 0.46 & 0.65 & 0.95 & 0.69 & 0.46 & 0.41 & 1.35 \\
\hline $\mathrm{Gd}$ & 3.63 & 1.94 & 0.78 & 4.32 & 0.45 & 7.65 & 7.12 & 3.00 & 5.01 & 3.22 & 2.63 & 3.89 & 5.08 \\
\hline $\mathrm{Tb}$ & 0.56 & 0.30 & 0.11 & 0.69 & 0.07 & 1.18 & 1.21 & 0.58 & 0.77 & 0.61 & 0.45 & 0.71 & 0.78 \\
\hline Dy & 3.26 & 1.57 & 0.63 & 3.94 & 0.40 & 6.61 & 7.30 & 3.20 & 4.71 & 3.34 & 2.64 & 4.13 & 4.44 \\
\hline Ho & 0.62 & 0.31 & 0.15 & 0.75 & 0.07 & 1.23 & 1.46 & 0.64 & 0.89 & 0.59 & 0.50 & 0.87 & 0.78 \\
\hline $\mathrm{Er}$ & 1.83 & 0.93 & 0.48 & 2.13 & 0.21 & 3.67 & 4.81 & 1.97 & 2.69 & 1.81 & 1.58 & 2.73 & 2.32 \\
\hline $\mathrm{Tm}$ & 0.26 & 0.13 & 0.06 & 0.31 & n.d. & 0.52 & 0.73 & 0.33 & 0.44 & 0.29 & 0.29 & 0.49 & 0.38 \\
\hline $\mathrm{Yb}$ & 1.82 & 0.93 & 0.55 & 1.99 & 0.24 & 3.16 & 4.97 & 2.26 & 3.54 & 2.14 & 2.14 & 3.51 & 2.37 \\
\hline $\mathrm{Lu}$ & 0.25 & 0.12 & 0.07 & 0.31 & 0.03 & 0.49 & 0.72 & 0.33 & 0.47 & 0.29 & 0.31 & 0.50 & 0.33 \\
\hline $\mathrm{Y}$ & 18.8 & 9.9 & 4.1 & 22.3 & 2.1 & 38.6 & 48.2 & 20.9 & 30.3 & 20.5 & 18.3 & 29.9 & 26.0 \\
\hline $\mathrm{Eu} / \mathrm{Eu}^{*}$ & 0.92 & 1.06 & 1.76 & 1.03 & 2.74 & 0.94 & 0.19 & 0.64 & 0.56 & 0.60 & 0.45 & 0.29 & 0.75 \\
\hline $\mathrm{La}_{\mathrm{N}} / \mathrm{Yb}_{\mathrm{N}}$ & 3.15 & 4.86 & 2.45 & 4.00 & 4.78 & 4.76 & 5.51 & 5.52 & 4.72 & 6.80 & 8.22 & 5.65 & 7.08 \\
\hline $\mathrm{La}_{\mathrm{N}} / \mathrm{Sm}_{\mathrm{N}}$ & 1.57 & 2.01 & 2.52 & 1.65 & 2.67 & 1.65 & 3.45 & 3.64 & 2.89 & 3.58 & 4.44 & 3.77 & 2.61 \\
\hline $\mathrm{Gd}_{\mathrm{N}} / \mathrm{Yb}_{\mathrm{N}}$ & 1.61 & 1.68 & 1.14 & 1.75 & 1.51 & 1.95 & 1.16 & 1.07 & 1.14 & 1.21 & 0.99 & 0.89 & 1.73 \\
\hline$\sum \mathrm{REE}$ & 65.04 & 42.97 & 12.48 & 81.10 & 10.00 & 160.86 & 200.79 & 88.44 & 142.17 & 110.91 & 121.05 & 150.37 & 139.49 \\
\hline $\mathrm{K} / \mathrm{Rb}$ & 684.86 & 407.52 & 1521.91 & 502.09 & 751.07 & 2057.28 & 248.33 & 336.59 & 204.25 & 246.06 & 248.19 & 241.34 & 382.12 \\
\hline $\mathrm{Rb} / \mathrm{Sr}$ & 0.02 & 0.01 & 0.00 & 0.02 & 0.00 & 0.00 & 3.36 & 0.51 & 0.44 & 0.40 & 1.72 & 4.23 & 0.11 \\
\hline $\mathrm{Rb} / \mathrm{Cs}$ & 20.00 & 23.57 & n.d. & 62.00 & n.d. & n.d. & 180.89 & 44.26 & 18.51 & 29.71 & 82.21 & 57.03 & 55.13 \\
\hline
\end{tabular}


Tab. 5 continued. Trace-element analyses (ppm).

\begin{tabular}{|c|c|c|c|c|c|c|c|c|c|c|c|c|c|}
\hline \multirow[b]{2}{*}{ Sample } & \multicolumn{13}{|c|}{ Gobi Tien Shan } \\
\hline & 18 & 19 & 20 & 21 & 22 & 23 & 24 & 25 & 26 & 27 & 28 & 29 & 30 \\
\hline $\mathrm{Rb}$ & 39.3 & 53.9 & 122.3 & 86.0 & 126.2 & 94.4 & 45.7 & 49.3 & 18.4 & 158.3 & 34.8 & 116.4 & 126.2 \\
\hline Cs & 1.3 & 1.8 & 3.9 & 2.1 & 2.0 & 5.5 & 2.3 & 1.6 & 3.5 & 3.0 & 1.2 & 4.5 & 2.2 \\
\hline $\mathrm{Sr}$ & 463.8 & 547.9 & 80.7 & 370.2 & 188.7 & 222.0 & 447.9 & 534.4 & 562.9 & 75.2 & 436.3 & 144.5 & 93.0 \\
\hline $\mathrm{Ba}$ & 798 & 511 & 292 & 577 & 730 & 575 & 490 & 402 & 265 & 313 & 301 & 605 & 306 \\
\hline $\mathrm{Nb}$ & 5.2 & 7.6 & 11.6 & 4.5 & 4.9 & 7.7 & 5.4 & 5.0 & 3.1 & 10.2 & 5.7 & 7.2 & 8.9 \\
\hline $\mathrm{Ta}$ & 0.3 & 0.5 & 0.9 & 0.5 & 0.6 & 0.6 & 0.4 & 0.4 & 0.2 & 1.3 & 0.4 & 0.9 & 0.8 \\
\hline $\mathrm{Zr}$ & 228.6 & 437.2 & 247.7 & 112.1 & 126.0 & 209.5 & 200.5 & 195.3 & 66.6 & 214.4 & 177.7 & 38.1 & 198.2 \\
\hline Hf & 6.1 & 10.6 & 7.8 & 3.6 & 3.7 & 5.9 & 5.4 & 5.6 & 1.7 & 7.2 & 4.2 & 2.0 & 7.3 \\
\hline $\mathrm{Ga}$ & 20.9 & 24.9 & 16.4 & 18.0 & 15.4 & 21.2 & 19.3 & 20.7 & 20.7 & 20.0 & 20.4 & 17.2 & 18.7 \\
\hline $\mathrm{Th}$ & 3.1 & 4.4 & 13.9 & 11.6 & 12.3 & 10.5 & 3.8 & 6.4 & 1.4 & 25.6 & 2.8 & 5.0 & 22.3 \\
\hline $\mathrm{U}$ & 1.2 & 1.4 & 6.5 & 1.7 & 1.8 & 2.2 & 1.4 & 1.9 & 0.5 & 4.3 & 0.8 & 1.1 & 3.9 \\
\hline $\mathrm{Ni}$ & 5.9 & 7.3 & 5.4 & 4.9 & 1.5 & 2.4 & 7.9 & 16.9 & 3.2 & 1.7 & 13.3 & 1.0 & 5.8 \\
\hline $\mathrm{Co}$ & 8.0 & 10.8 & 1.1 & 5.1 & 2.8 & 6.6 & 16.5 & 13.6 & 39.9 & 1.8 & 24.2 & n.d. & 3.8 \\
\hline $\mathrm{V}$ & 74 & 103 & 13 & 37 & 21 & 81 & 158 & 117 & 587 & 15 & 192 & n.d. & 21 \\
\hline $\mathrm{Sc}$ & 10 & 12 & 8 & 4 & 4 & 25 & 16 & 9 & 34 & 2 & 30 & n.d. & 2 \\
\hline $\mathrm{Pb}$ & 1.1 & 2.4 & 7.1 & 5.4 & 5.1 & 26.7 & 5.6 & 1.7 & 1.6 & 13.5 & 3.8 & 18.1 & 8.6 \\
\hline $\mathrm{Cu}$ & 10.5 & 15.3 & 5.4 & 1.6 & 1.7 & 3.9 & 12.9 & 9.9 & 18.4 & 2.4 & 24.1 & 1.3 & 11.6 \\
\hline $\mathrm{Zn}$ & 49 & 65 & 44 & 39 & 30 & 40 & 81 & 29 & 56 & 30 & 26 & 33 & 21 \\
\hline $\mathrm{Sn}$ & 2 & 3 & 4 & 1 & 4 & 2 & 1 & 1 & 1 & 2 & 1 & 3 & 3 \\
\hline W & 0.3 & 0.4 & 1.4 & 0.3 & 0.8 & 1.3 & 0.4 & 0.3 & 0.1 & 0.8 & 0.6 & 0.9 & 0.7 \\
\hline Mo & 0.6 & 0.8 & 2.0 & 0.1 & 0.3 & 0.3 & 0.3 & 0.2 & 0.3 & 0.5 & 0.5 & 0.1 & 0.4 \\
\hline $\mathrm{Cd}$ & n.d. & n.d. & 0.1 & n.d. & 0.1 & 0.1 & n.d. & n.d. & n.d. & n.d. & n.d. & n.d. & n.d. \\
\hline As & 0.7 & 1.5 & 6.4 & 2.5 & 1.2 & 3.2 & 5.7 & 1.3 & 4.9 & 0.5 & 12.1 & 1.1 & 2.2 \\
\hline $\mathrm{Sb}$ & n.d. & 0.1 & 0.2 & n.d. & n.d. & 0.3 & 0.1 & 0.1 & 0.1 & 0.1 & 0.2 & 0.1 & 0.1 \\
\hline $\mathrm{Bi}$ & n.d. & n.d. & n.d. & n.d. & n.d. & n.d. & n.d. & n.d. & n.d. & 0.1 & n.d. & 0.1 & n.d. \\
\hline $\mathrm{Au}(\mathrm{ppb})$ & 1.5 & 2.4 & n.d. & 1.3 & n.d. & 2.1 & n.d. & n.d. & 1.5 & 0.9 & n.d. & 1.7 & n.d. \\
\hline $\mathrm{Ag}$ & n.d. & n.d. & n.d. & n.d. & n.d. & n.d. & n.d. & n.d. & n.d. & n.d. & n.d. & n.d. & n.d. \\
\hline $\mathrm{Hg}$ & n.d. & n.d. & 0.02 & 0.02 & 0.01 & 0.05 & 0.08 & 0.04 & 0.04 & 0.03 & 0.03 & 0.02 & 0.02 \\
\hline $\mathrm{Tl}$ & 0.1 & 0.1 & n.d. & n.d. & n.d. & n.d. & n.d. & n.d. & n.d. & 0.1 & n.d. & n.d. & 0.1 \\
\hline $\mathrm{La}$ & 21.2 & 25.1 & 36.9 & 20.6 & 21.6 & 27.8 & 19.6 & 23.5 & 5.6 & 40.7 & 19.6 & 11.3 & 31.3 \\
\hline $\mathrm{Ce}$ & 43.5 & 56.3 & 81.7 & 41.5 & 45.9 & 56.4 & 40.7 & 49.1 & 11.6 & 83.9 & 41.7 & 23.4 & 75.4 \\
\hline $\operatorname{Pr}$ & 5.43 & 7.88 & 10.03 & 4.57 & 4.81 & 6.92 & 5.37 & 6.11 & 1.57 & 10.13 & 5.37 & 2.48 & 7.91 \\
\hline $\mathrm{Nd}$ & 24.5 & 40.9 & 41.7 & 18.6 & 18.9 & 32.0 & 26.7 & 29.0 & 8.3 & 42.4 & 26.2 & 10.7 & 34.7 \\
\hline $\mathrm{Sm}$ & 4.4 & 8.7 & 8.4 & 3.1 & 3.6 & 7.2 & 6.1 & 5.6 & 2.0 & 9.3 & 5.7 & 2.4 & 6.5 \\
\hline $\mathrm{Eu}$ & 1.35 & 2.04 & 0.99 & 0.73 & 0.72 & 1.34 & 1.75 & 1.33 & 0.90 & 0.71 & 1.54 & 0.36 & 0.67 \\
\hline $\mathrm{Gd}$ & 4.08 & 8.56 & 7.60 & 2.29 & 3.75 & 7.07 & 6.38 & 5.01 & 2.13 & 8.54 & 6.01 & 2.04 & 6.03 \\
\hline $\mathrm{Tb}$ & 0.61 & 1.35 & 1.22 & 0.37 & 0.67 & 1.24 & 1.06 & 0.76 & 0.38 & 1.60 & 0.89 & 0.39 & 1.03 \\
\hline Dy & 3.38 & 7.34 & 6.89 & 2.05 & 3.86 & 7.23 & 6.15 & 3.88 & 2.14 & 10.06 & 5.08 & 2.10 & 6.52 \\
\hline Ho & 0.66 & 1.34 & 1.35 & 0.39 & 0.80 & 1.34 & 1.20 & 0.73 & 0.38 & 1.81 & 0.94 & 0.40 & 1.17 \\
\hline $\mathrm{Er}$ & 1.75 & 3.78 & 3.98 & 1.07 & 2.43 & 3.93 & 3.47 & 2.00 & 1.07 & 5.79 & 2.72 & 1.11 & 3.65 \\
\hline $\mathrm{Tm}$ & 0.27 & 0.58 & 0.65 & 0.18 & 0.41 & 0.61 & 0.54 & 0.31 & 0.17 & 0.92 & 0.41 & 0.19 & 0.60 \\
\hline $\mathrm{Yb}$ & 1.87 & 3.81 & 4.63 & 1.27 & 2.93 & 4.50 & 3.56 & 2.34 & 1.18 & 7.00 & 2.90 & 1.33 & 4.61 \\
\hline $\mathrm{Lu}$ & 0.26 & 0.51 & 0.65 & 0.17 & 0.42 & 0.63 & 0.56 & 0.32 & 0.17 & 0.95 & 0.38 & 0.17 & 0.59 \\
\hline $\mathrm{Y}$ & 19.6 & 40.9 & 43.8 & 12.5 & 25.1 & 42.8 & 37.1 & 22.8 & 11.8 & 62.4 & 29.2 & 14.1 & 39.0 \\
\hline $\mathrm{Eu} / \mathrm{Eu}^{*}$ & 0.97 & 0.72 & 0.38 & 0.84 & 0.60 & 0.57 & 0.86 & 0.77 & 1.33 & 0.24 & 0.80 & 0.50 & 0.33 \\
\hline $\mathrm{La}_{\mathrm{N}} / \mathrm{Yb}_{\mathrm{N}}$ & 7.64 & 4.44 & 5.37 & 10.94 & 4.97 & 4.17 & 3.71 & 6.77 & 3.20 & 3.92 & 4.56 & 5.73 & 4.58 \\
\hline $\mathrm{La}_{\mathrm{N}} / \mathrm{Sm}_{\mathrm{N}}$ & 3.03 & 1.81 & 2.76 & 4.18 & 3.77 & 2.43 & 2.02 & 2.64 & 1.76 & 2.75 & 2.16 & 2.96 & 3.03 \\
\hline $\mathrm{Gd}_{\mathrm{N}} / \mathrm{Yb}_{\mathrm{N}}$ & 1.76 & 1.81 & 1.32 & 1.46 & 1.03 & 1.27 & 1.45 & 1.73 & 1.46 & 0.98 & 1.67 & 1.24 & 1.06 \\
\hline$\sum \mathrm{REE}$ & 113.26 & 168.19 & 206.69 & 96.89 & 110.80 & 158.21 & 123.14 & 129.99 & 37.59 & 223.81 & 119.44 & 58.37 & 180.68 \\
\hline $\mathrm{K} / \mathrm{Rb}$ & 384.44 & 238.72 & 273.54 & 253.87 & 235.49 & 238.31 & 316.07 & 346.87 & 302.28 & 237.55 & 295.79 & 226.07 & 276.27 \\
\hline $\mathrm{Rb} / \mathrm{Sr}$ & 0.08 & 0.10 & 1.52 & 0.23 & 0.67 & 0.43 & 0.10 & 0.09 & 0.03 & 2.11 & 0.08 & 0.81 & 1.36 \\
\hline $\mathrm{Rb} / \mathrm{Cs}$ & 30.23 & 29.94 & 31.36 & 40.95 & 63.10 & 17.16 & 19.87 & 30.81 & 5.26 & 52.77 & 29.00 & 25.87 & 57.36 \\
\hline
\end{tabular}


Tab. 5 continued. Trace-element analyses (ppm).

\begin{tabular}{|c|c|c|c|c|c|c|c|c|c|c|c|c|c|}
\hline \multirow[b]{2}{*}{ Sample } & \multicolumn{5}{|c|}{ Gurvan Khar } & \multicolumn{5}{|c|}{ Ikch Bayan } & \multicolumn{3}{|c|}{ Trans-Altay } \\
\hline & 31 & 32 & 33 & 34 & 35 & 36 & 37 & 38 & 39 & 40 & 41 & 42 & 43 \\
\hline $\mathrm{Rb}$ & 14.1 & 16.9 & 14.5 & 25.9 & 7.2 & 126.3 & 93.6 & 122.4 & 66.8 & 83.4 & 136.1 & 49.2 & 44.2 \\
\hline $\mathrm{Cs}$ & 0.3 & 0.3 & 0.4 & 0.6 & n.d. & 3.0 & 1.8 & 2.0 & 0.9 & 1.0 & 1.6 & 0.4 & 0.9 \\
\hline $\mathrm{Sr}$ & 829.6 & 783.7 & 766.0 & 578.3 & 1107.5 & 170.8 & 143.3 & 171.3 & 166.6 & 227.1 & 26.6 & 129.5 & 562.6 \\
\hline $\mathrm{Ba}$ & 447 & 557 & 506 & 418 & 399 & 526 & 841 & 742 & 870 & 809 & 86 & 448 & 709 \\
\hline $\mathrm{Nb}$ & 3.1 & 2.2 & 2.1 & 3.3 & 2.7 & 7.0 & 7.6 & 6.6 & 13.1 & 9.3 & 8.8 & 2.1 & 7.7 \\
\hline $\mathrm{Ta}$ & 0.2 & 0.1 & 0.1 & 0.2 & 0.1 & 0.5 & 0.4 & 0.7 & 0.6 & 0.9 & 0.6 & 0.3 & 0.6 \\
\hline $\mathrm{Zr}$ & 77.2 & 57.0 & 51.9 & 105.6 & 67.7 & 121.6 & 154.7 & 88.2 & 339.2 & 150.2 & 185.3 & 68.6 & 203.2 \\
\hline $\mathrm{Hf}$ & 2.3 & 2.1 & 1.8 & 3.0 & 2.0 & 4.0 & 5.0 & 3.6 & 9.1 & 5.1 & 7.0 & 3.0 & 6.1 \\
\hline $\mathrm{Ga}$ & 18.8 & 17.8 & 16.8 & 17.7 & 23.6 & 16.1 & 19.6 & 13.9 & 17.9 & 16.1 & 19.6 & 11.2 & 18.3 \\
\hline $\mathrm{Th}$ & 1.4 & 0.7 & 0.4 & 2.1 & 0.3 & 6.2 & 7.2 & 14.0 & 6.0 & 15.5 & 9.3 & 9.7 & 6.1 \\
\hline $\mathrm{U}$ & 0.7 & 0.3 & 0.4 & 0.6 & 0.3 & 1.3 & 1.6 & 3.5 & 1.9 & 2.6 & 2.5 & 1.4 & 1.5 \\
\hline $\mathrm{Ni}$ & 4.5 & 3.1 & 3.3 & 14.9 & 12.1 & 6.1 & 4.8 & 6.6 & 5.7 & 9.2 & 6.5 & 6.3 & 4.3 \\
\hline $\mathrm{Co}$ & 4.5 & 2.6 & 2.2 & 13.3 & 15.3 & 3.3 & 1.8 & 1.6 & 2.6 & 3.1 & 1.0 & 1.8 & 4.4 \\
\hline V & 56 & 24 & 26 & 138 & 186 & 20 & 8 & 7 & 22 & 31 & 8 & 17 & 56 \\
\hline $\mathrm{Sc}$ & 10 & 5 & 6 & 21 & 15 & 4 & 9 & 8 & 14 & 10 & 8 & 4 & 10 \\
\hline $\mathrm{Pb}$ & 0.3 & 0.4 & 0.7 & 1.2 & 2.0 & 2.8 & 6.5 & 4.3 & 6.3 & 2.8 & 8.7 & 4.5 & 4.4 \\
\hline $\mathrm{Cu}$ & 5.5 & 4.8 & 4.3 & 61.6 & 75.7 & 11.2 & 14.6 & 9.4 & 5.2 & 12.5 & 12.3 & 7.7 & 7.9 \\
\hline $\mathrm{Zn}$ & 38 & 37 & 42 & 43 & 75 & 29 & 34 & 21 & 48 & 37 & 33 & 12 & 7 \\
\hline $\mathrm{Sn}$ & n.d. & n.d. & n.d. & n.d. & n.d. & 2 & 2 & n.d. & 3 & 2 & 2 & n.d. & 2 \\
\hline W & 0.1 & 0.2 & 1.6 & 0.2 & 0.2 & 0.3 & 0.3 & 0.2 & 0.5 & 0.3 & 0.8 & 0.2 & 0.4 \\
\hline Mo & 0.2 & 0.4 & 0.2 & 1.0 & 0.9 & 0.6 & 0.7 & 0.5 & 0.4 & 0.7 & 2.3 & 0.5 & 0.4 \\
\hline $\mathrm{Cd}$ & n.d. & n.d. & n.d. & n.d. & 0.1 & n.d. & n.d. & n.d. & 0.1 & n.d. & 0.1 & n.d. & n.d. \\
\hline As & 0.5 & n.d. & 0.5 & 0.8 & n.d. & 0.9 & 0.5 & n.d. & n.d. & n.d. & 0.8 & 1.0 & 3.9 \\
\hline $\mathrm{Sb}$ & n.d. & n.d. & n.d. & n.d. & n.d. & n.d. & n.d. & n.d. & n.d. & n.d. & 0.1 & n.d. & 0.1 \\
\hline $\mathrm{Bi}$ & n.d. & n.d. & n.d. & n.d. & 0.1 & n.d. & n.d. & n.d. & n.d. & 0.1 & 0.1 & n.d. & 0.1 \\
\hline $\mathrm{Au}(\mathrm{ppb})$ & n.d. & 0.5 & 0.7 & 0.6 & 2.1 & n.d. & n.d. & 2.7 & n.d. & n.d. & 2.7 & 6.2 & 1.4 \\
\hline $\mathrm{Ag}$ & n.d. & n.d. & n.d. & n.d. & n.d. & n.d. & n.d. & n.d. & n.d. & n.d. & n.d. & n.d. & n.d. \\
\hline $\mathrm{Hg}$ & 0.01 & n.d. & n.d. & n.d. & n.d. & n.d. & n.d. & n.d. & n.d. & 0.01 & n.d. & n.d. & n.d. \\
\hline $\mathrm{Tl}$ & n.d. & n.d. & n.d. & n.d. & n.d. & 0.1 & 0.1 & n.d. & n.d. & n.d. & n.d. & n.d. & n.d. \\
\hline $\mathrm{La}$ & 8.0 & 6.5 & 4.9 & 9.3 & 9.1 & 18.3 & 20.1 & 25.3 & 43.5 & 28.7 & 32.8 & 19.9 & 19.7 \\
\hline $\mathrm{Ce}$ & 17.3 & 14.0 & 11.0 & 19.5 & 20.6 & 34.6 & 44.8 & 46.0 & 89.3 & 55.7 & 64.5 & 40.1 & 37.5 \\
\hline $\operatorname{Pr}$ & 2.18 & 1.76 & 1.32 & 2.44 & 2.80 & 3.98 & 5.16 & 4.86 & 11.14 & 6.18 & 7.19 & 3.51 & 4.31 \\
\hline $\mathrm{Nd}$ & 10.1 & 8.1 & 6.0 & 11.7 & 13.5 & 16.8 & 23.0 & 18.5 & 47.8 & 25.6 & 28.9 & 12.4 & 18.6 \\
\hline $\mathrm{Sm}$ & 1.9 & 1.6 & 1.2 & 2.4 & 2.8 & 3.0 & 4.4 & 3.2 & 8.6 & 4.6 & 4.7 & 2.0 & 3.5 \\
\hline $\mathrm{Eu}$ & 0.55 & 0.35 & 0.30 & 0.71 & 0.85 & 0.54 & 0.37 & 0.40 & 1.24 & 0.66 & 0.37 & 0.43 & 0.68 \\
\hline $\mathrm{Gd}$ & 1.59 & 1.69 & 1.27 & 2.37 & 2.02 & 2.67 & 3.72 & 2.23 & 6.61 & 3.40 & 3.53 & 1.31 & 3.38 \\
\hline $\mathrm{Tb}$ & 0.25 & 0.29 & 0.18 & 0.38 & 0.31 & 0.46 & 0.63 & 0.42 & 1.15 & 0.56 & 0.57 & 0.21 & 0.54 \\
\hline Dy & 1.56 & 1.83 & 1.09 & 2.18 & 1.75 & 2.65 & 3.90 & 2.17 & 6.56 & 3.47 & 3.18 & 1.23 & 3.02 \\
\hline Ho & 0.28 & 0.37 & 0.21 & 0.44 & 0.29 & 0.53 & 0.77 & 0.46 & 1.20 & 0.68 & 0.63 & 0.24 & 0.57 \\
\hline $\mathrm{Er}$ & 0.93 & 1.22 & 0.67 & 1.42 & 0.89 & 1.67 & 2.40 & 1.30 & 3.75 & 2.12 & 2.06 & 0.98 & 1.83 \\
\hline $\mathrm{Tm}$ & 0.15 & 0.19 & 0.10 & 0.20 & 0.12 & 0.26 & 0.37 & 0.25 & 0.58 & 0.32 & 0.35 & 0.15 & 0.29 \\
\hline $\mathrm{Yb}$ & 1.02 & 1.31 & 0.73 & 1.39 & 0.86 & 1.83 & 2.50 & 1.70 & 3.69 & 2.54 & 2.38 & 1.26 & 2.07 \\
\hline $\mathrm{Lu}$ & 0.16 & 0.20 & 0.09 & 0.20 & 0.12 & 0.28 & 0.35 & 0.26 & 0.56 & 0.38 & 0.36 & 0.21 & 0.28 \\
\hline $\mathrm{Y}$ & 10.0 & 12.9 & 7.2 & 14.3 & 9.5 & 17.1 & 24.9 & 15.2 & 39.8 & 22.5 & 21.1 & 8.6 & 19.4 \\
\hline $\mathrm{Eu} / \mathrm{Eu}^{*}$ & 0.97 & 0.65 & 0.74 & 0.91 & 1.09 & 0.58 & 0.28 & 0.46 & 0.50 & 0.51 & 0.28 & 0.81 & 0.60 \\
\hline $\mathrm{La}_{\mathrm{N}} / \mathrm{Yb}_{\mathrm{N}}$ & 5.29 & 3.35 & 4.53 & 4.51 & 7.13 & 6.74 & 5.42 & 10.03 & 7.95 & 7.62 & 9.29 & 10.65 & 6.42 \\
\hline $\mathrm{La}_{\mathrm{N}} / \mathrm{Sm}_{\mathrm{N}}$ & 2.65 & 2.56 & 2.57 & 2.44 & 2.04 & 3.84 & 2.87 & 4.97 & 3.18 & 3.92 & 4.39 & 6.26 & 3.54 \\
\hline $\mathrm{Gd}_{\mathrm{N}} / \mathrm{Yb}_{\mathrm{N}}$ & 1.26 & 1.04 & 1.40 & 1.38 & 1.90 & 1.18 & 1.20 & 1.06 & 1.45 & 1.08 & 1.20 & 0.84 & 1.32 \\
\hline$\sum \mathrm{REE}$ & 45.97 & 39.41 & 29.06 & 54.63 & 56.01 & 87.57 & 112.47 & 107.05 & 225.68 & 134.91 & 151.52 & 83.93 & 96.27 \\
\hline $\mathrm{K} / \mathrm{Rb}$ & 600.52 & 579.62 & 681.28 & 432.69 & 691.78 & 270.79 & 364.51 & 292.99 & 502.05 & 356.34 & 314.73 & 836.88 & 617.90 \\
\hline $\mathrm{Rb} / \mathrm{Sr}$ & 0.02 & 0.02 & 0.02 & 0.04 & 0.01 & 0.74 & 0.65 & 0.71 & 0.40 & 0.37 & 5.12 & 0.38 & 0.08 \\
\hline $\mathrm{Rb} / \mathrm{Cs}$ & 47.00 & 56.33 & 36.25 & 43.17 & n.d. & 42.10 & 52.00 & 61.20 & 74.22 & 83.40 & 85.06 & 123.00 & 49.11 \\
\hline
\end{tabular}


Tab. 5 continued. Trace-element analyses (ppm).

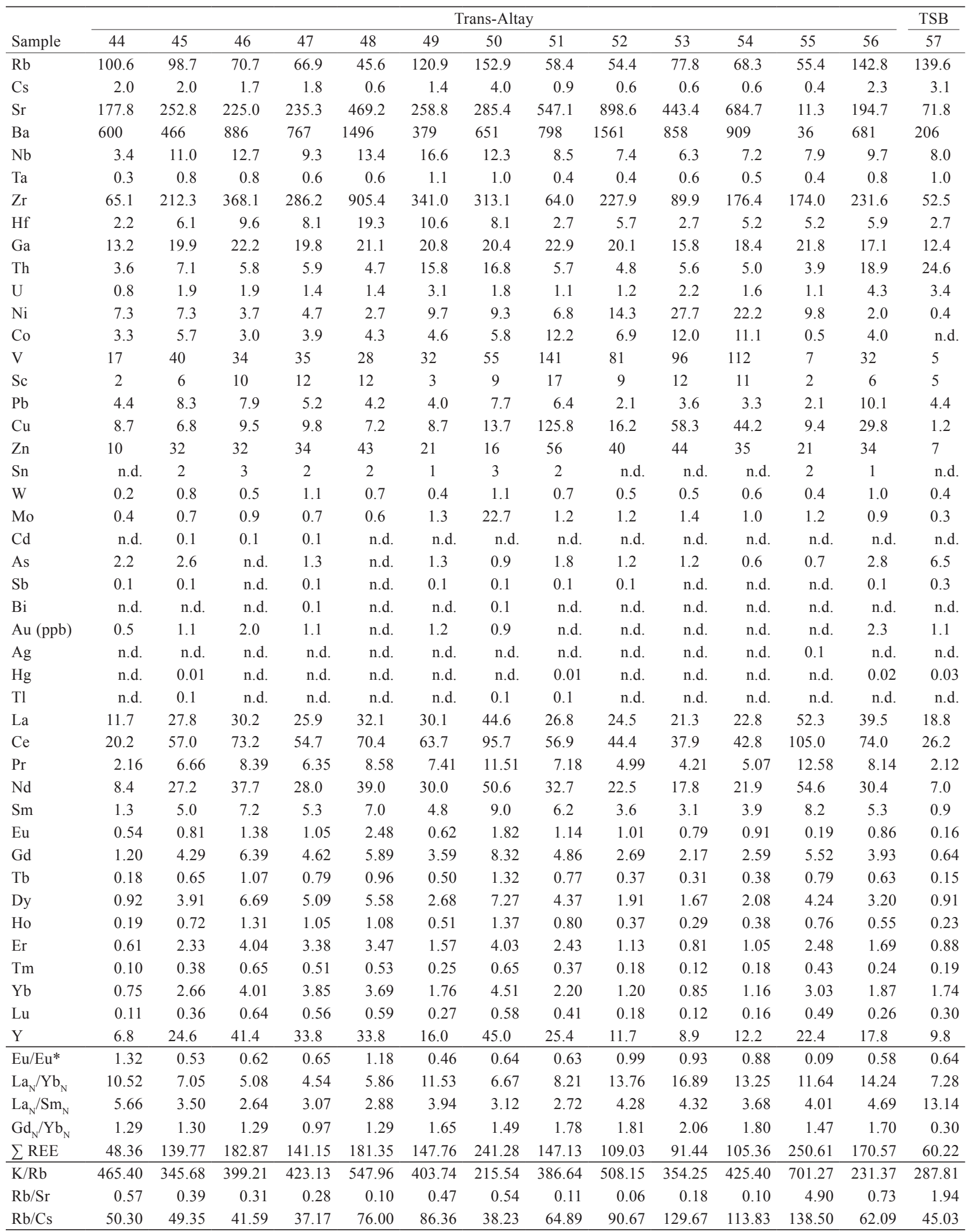



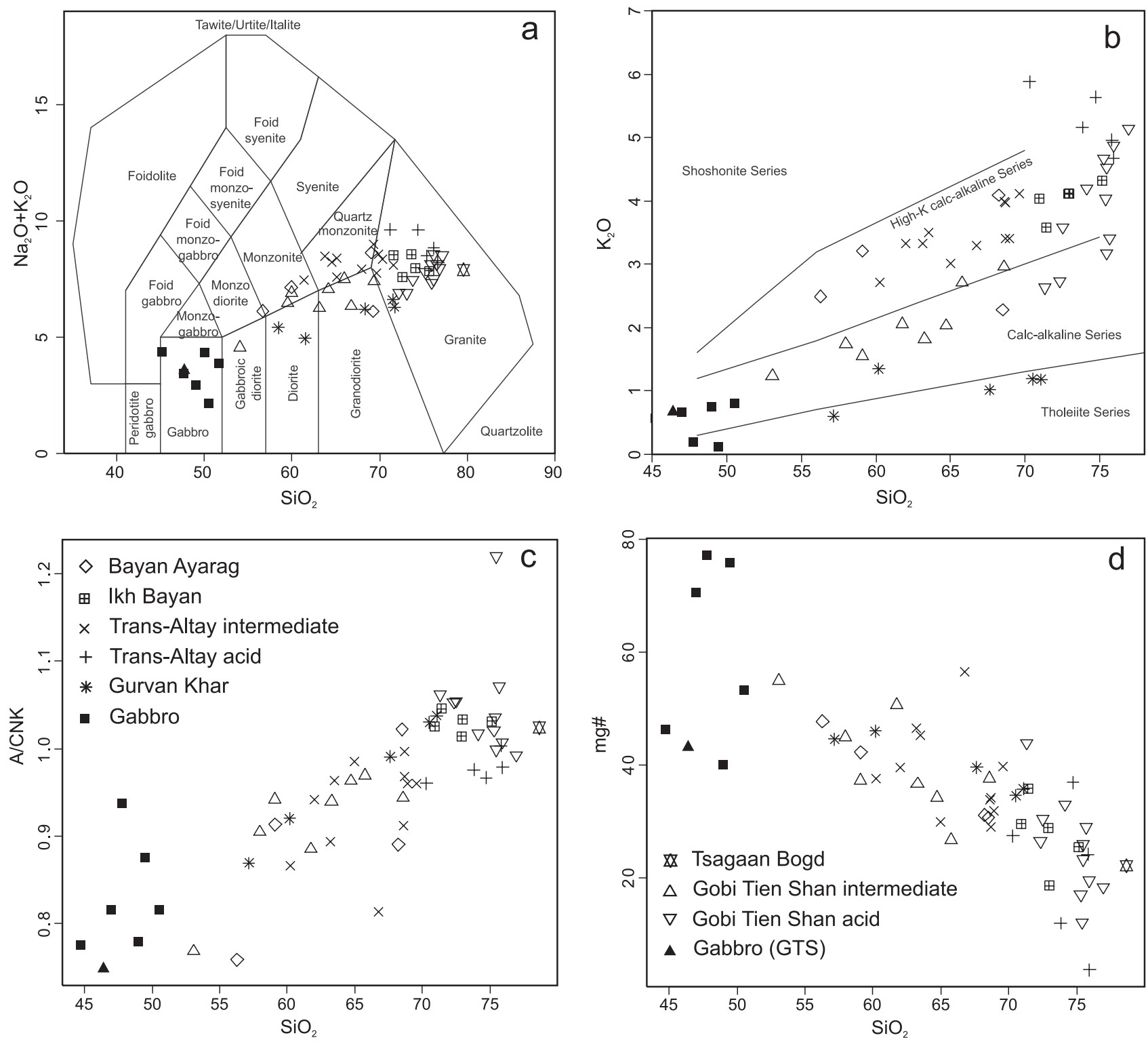

Fig. 6 Major-element chemistry of the plutonic rocks in the Trans-Altay Gobi: a - TAS classification (Middlemost 1994); b - $\mathrm{SiO}_{2}$ vs. $\mathrm{K}_{2} \mathrm{O}$ plot of Peccerillo and Taylor (1976); $\mathbf{c}-$ plot of alumina saturation index (Shand 1947) vs. $\mathrm{SiO}_{2} ; \mathbf{d}-$ binary plot of $\mathrm{mg} \# \mathrm{vs} . \mathrm{SiO}_{2}, \mathrm{mg} \#=100(\mathrm{MgO} /(\mathrm{FeO}$ $+\mathrm{MgO}))$ in $\mathrm{mol} \%$.

anomaly $\left(\mathrm{Eu} / \mathrm{Eu}^{*}=1.7-2.7\right)$, which is otherwise negligible $\left(\mathrm{Eu} / \mathrm{Eu}^{*}=0.92-1.06\right)$ (Fig. 10b).

\subsection{Gobi Tien Shan Intrusive Complex}

Geochemical data from the Gobi Tien Shan Intrusive Complex correlate well with petrographic classification established for the individual rock types. Analysed samples can be classified as granite, granodiorite and quartz monzodiorite on the basis of the $\mathrm{Q}^{\prime}-\mathrm{ANOR}$ diagram (Fig. 3). They are calc-alkaline and belong to the medium K-series (Peccerillo and Taylor 1976). As for the Trans-Altay Intrusive Complex granites, two trends can be distinguished in $\mathrm{SiO}_{2}-\mathrm{K}_{2} \mathrm{O}$ diagram, whereby the rocks with $\mathrm{SiO}_{2}>70$ wt. \% are of high-K character (Fig. 6b). The $\mathrm{K}_{2} \mathrm{O} / \mathrm{Na}_{2} \mathrm{O}$ ratios are very variable $(0.3-0.8)$ for the intermediate rocks as well as for samples with $\mathrm{SiO}_{2}>70$ wt. \% (0.6-1.5). The rocks are metaluminous $(\mathrm{A} / \mathrm{CNK}=$ $0.7-1.2)$; elevated values of Shand's index probably reflect secondary loss of alkalies accompanying intense sericitization. The $\mathrm{K} / \mathrm{Rb}$ ratios fall between $c .200$ and 390. The $\mathrm{Rb} / \mathrm{Sr}$ ratios are low (0.1-0.4) in intermediate rocks, but generally higher although variable (0.2-4.2) in acid rocks (Fig. 7). The NMORB-normalized spider plots (Fig. 8) display marked depletion in $\mathrm{Nb}, \mathrm{P}$, Ti while $\mathrm{Cs}$ and $\mathrm{Pb}$ are generally enriched; $\mathrm{P}, \mathrm{Zr}$ and $\mathrm{Ti}$ are slightly depleted, $\mathrm{Nd}$ 

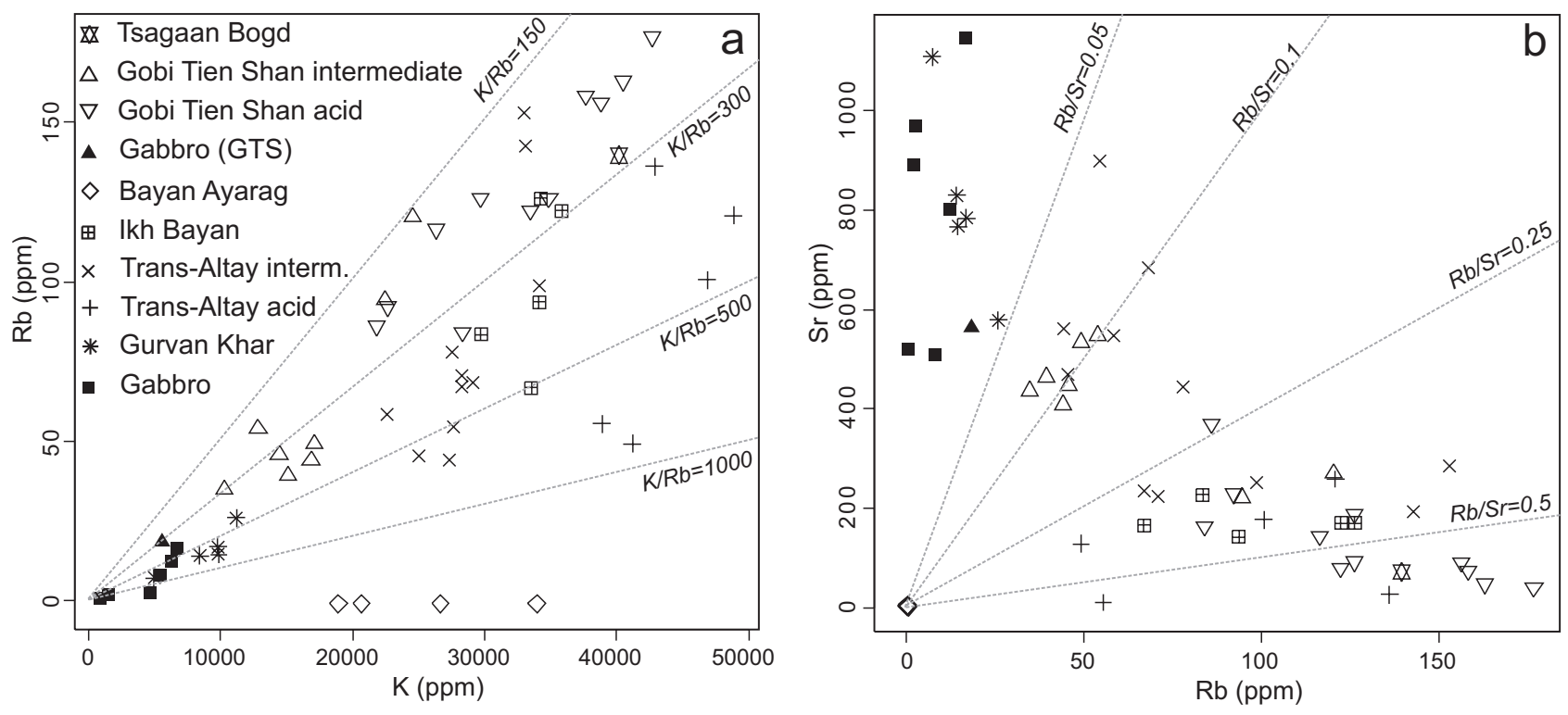

Fig. 7 Binary plots $\mathrm{K}-\mathrm{Rb}(\mathrm{a})$ and $\mathrm{Rb}-\mathrm{Sr}$ (b) for plutonic rocks of the Trans-Altay Gobi.

slightly enriched. The Ba, $\mathrm{Sr}$ and Th contents are consistently, slightly to moderately, enriched in acid rocks but are variable in intermediate rocks. Chondrite-normalized REE patterns (Fig. 9) show moderate to strong fractionation of LREE, while HREE display flat trends $\left(\mathrm{La}_{\mathrm{N}} / \mathrm{Yb}_{\mathrm{N}}=3.7-\right.$ 10.9, $\left.\mathrm{La}_{\mathrm{N}} / \mathrm{Sm}_{\mathrm{N}}=1.8-4.4, \mathrm{Gd}_{\mathrm{N}} / \mathrm{Yb}_{\mathrm{N}}=0.9-1.8\right)$. Negative $\mathrm{Eu}$ anomaly is well developed in acid $\left(\mathrm{Eu} / \mathrm{Eu}^{*}=0.2-0.6\right)$ and less so in intermediate rocks $\left(\mathrm{Eu} / \mathrm{Eu}^{*}=0.6-0.9\right)$.

There are no trace-element data available from the Naran Sevest Massif, but the major-element analyses suggest similarity with the Zamyn Belgekh Pluton (Šourek et al. 2003).

\subsection{Tsagaan Bogd Massif}

The only available sample from the Tsagaan Bogd granite has an affinity to alkali feldspar granite, and it is very acid $\left(\mathrm{SiO}_{2}=79\right.$ wt. \%). The $\mathrm{K}_{2} \mathrm{O} / \mathrm{Na}_{2} \mathrm{O}$ ratio is high (1.6) and $\mathrm{A} / \mathrm{CNK}$ close to unity. Its $\mathrm{K} / \mathrm{Rb}$ ratio is 287 and $\mathrm{Rb} / \mathrm{Sr}$ ratio 1.9 (Fig. 7). The NMORB-normalized spider plot shows marked depletion in $\mathrm{Ba}, \mathrm{Nb}, \mathrm{P}$ and $\mathrm{Ti}$, while $\mathrm{Cs}$, Th, $\mathrm{K}$, and $\mathrm{Pb}$ are enriched (Fig. 8) This trend is very similar to the rocks of GTS in LILE but the REE abundances are rather different. Chondrite-normalized pattern is V-shaped (Fig. 9), reflecting strong fractionation of LREE $\left(\mathrm{La}_{\mathrm{N}} / \mathrm{Sm}_{\mathrm{N}}=13.14\right)$ and enrichment in $\operatorname{HREE}\left(\mathrm{Gd}_{\mathrm{N}} / \mathrm{Yb}_{\mathrm{N}}=0.3\right)$.

\section{Laser ablation ICP-MS dating of zircons}

The radiometric ages are not available yet in the TransAltay Gobi. Filippova et al. (1990a) described the Gobi
Tien Shan Intrusive Complex as being Late DevonianEarly Carboniferous based on K-Ar dating. No original results were, nevertheless, presented in their report. Sample of granodiorite from NW part of the Trans-Altay Gobi corresponding to the Gurvan Khar Massif has been dated by the zircon evaporation method at $399 \pm 1 \mathrm{Ma}$ by A. Kröner (K. Schulmann pers. comm).

Most of the zircons extracted from the nine granitic samples showed substantial heterogeneity in ages, often on scale smaller than the analysed volume of zircon. Therefore only 50, out of the total of 123 analyses carried out on the unknown zircon samples, produced ages that could be interpreted as single-component ages corresponding to the zircon crystallization from the granitic melt. Yet, small number of concordant data points allows more precise age determination within the period of the Variscan magmatic activity in the studied area. Available data (Fig. 11) characterize the evolution of the Zamyn Belgekh Pluton, one sample is from an equivalent of the Trans-Altay granite in GTS and one from the Bayan Ayrag Massif.

Regression of data points from sample D-28/1145 (biotite-hornblende granodiorite) gives the Early Carboniferous upper concordia intercept age of $354 \pm 37$ Ma. However, zircon analyses from this sample form two separate clusters in the concordia diagram, first represented by four slightly discordant data points with a weighted mean ${ }^{238} \mathrm{U}-206 \mathrm{~Pb}$ age of $309 \pm 9 \mathrm{Ma}$, second being somewhat older with one concordant point yielding a concordia age of $346 \pm 14 \mathrm{Ma}$. All zircons from sample D-28/1145 are euhedral with igneous oscillatory zoning, and hence their ages can be interpreted as recording two separate phases (309 and $346 \mathrm{Ma}$ ) or one 

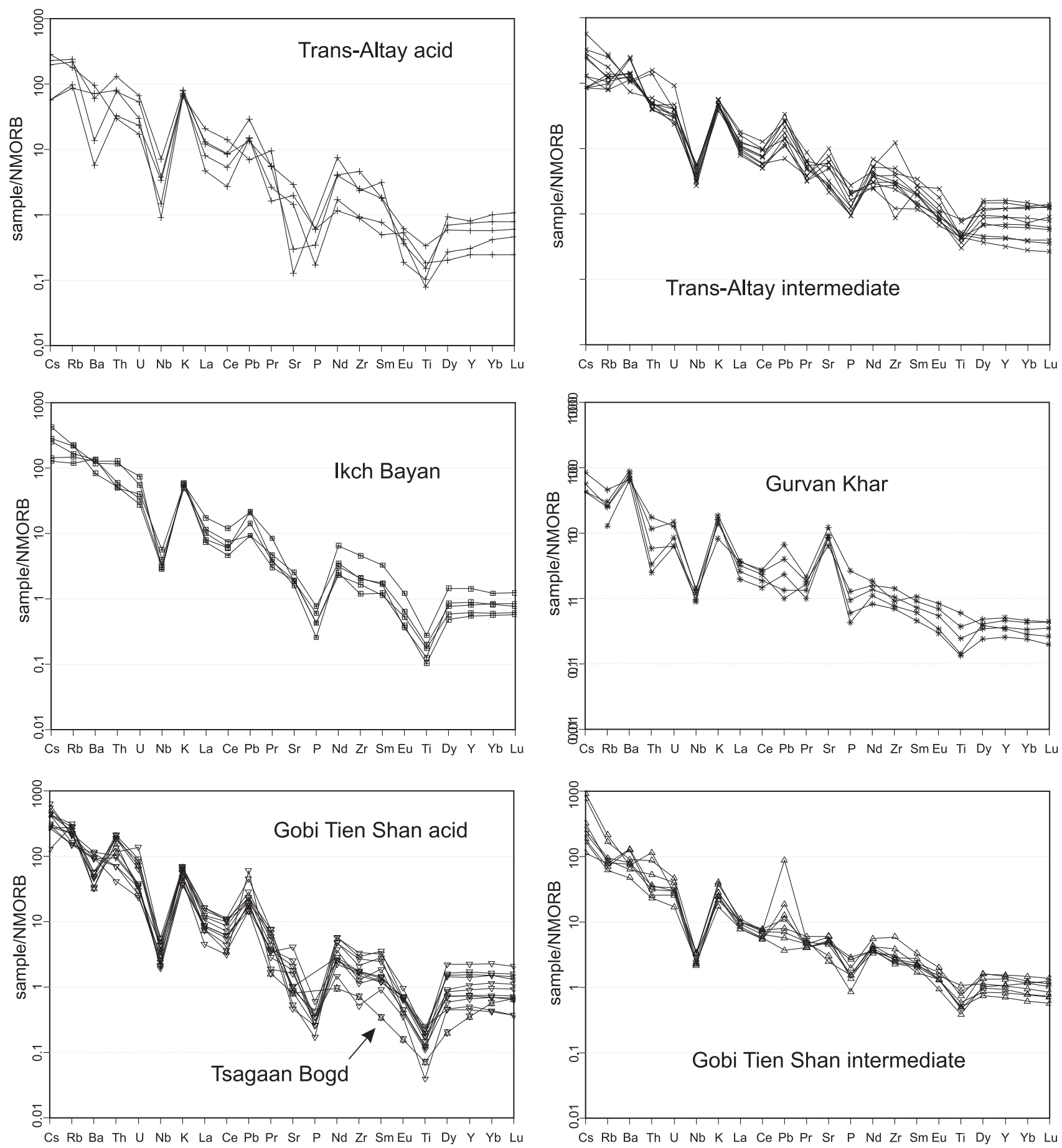

Fig. 8 NMORB (Sun and McDonough 1989) normalized spider diagrams for granitic rocks of the Trans-Altay Gobi.

prolonged phase of zircon magmatic crystallization during the Carboniferous period. All analysed zircons from sample E-27/1138 (biotite-hornblende granodiorite) are slightly discordant, giving a weighted mean ${ }^{238} \mathrm{U}-{ }^{206} \mathrm{~Pb}$ age of $335 \pm 15 \mathrm{Ma}$ and a corresponding lower concordia intercept age of $326 \pm 33 \mathrm{Ma}$. Given the morphology and character of oscillatory zoning in the zircons, this age can again be interpreted as corresponding to the zircon magmatic crystallization. On the other hand, samples A-26/1018 (biotite-hornblende granodiorite) and B27/1149 (leucogranite) yielded somewhat younger (Late Carboniferous-Early Permian) weighted mean ${ }^{238} \mathrm{U}-{ }^{206} \mathrm{~Pb}$ ages of $299 \pm 8 \mathrm{Ma}$ and $288 \pm 15 \mathrm{Ma}$ (7 more concordant data points), respectively. Younger still lower concordia 

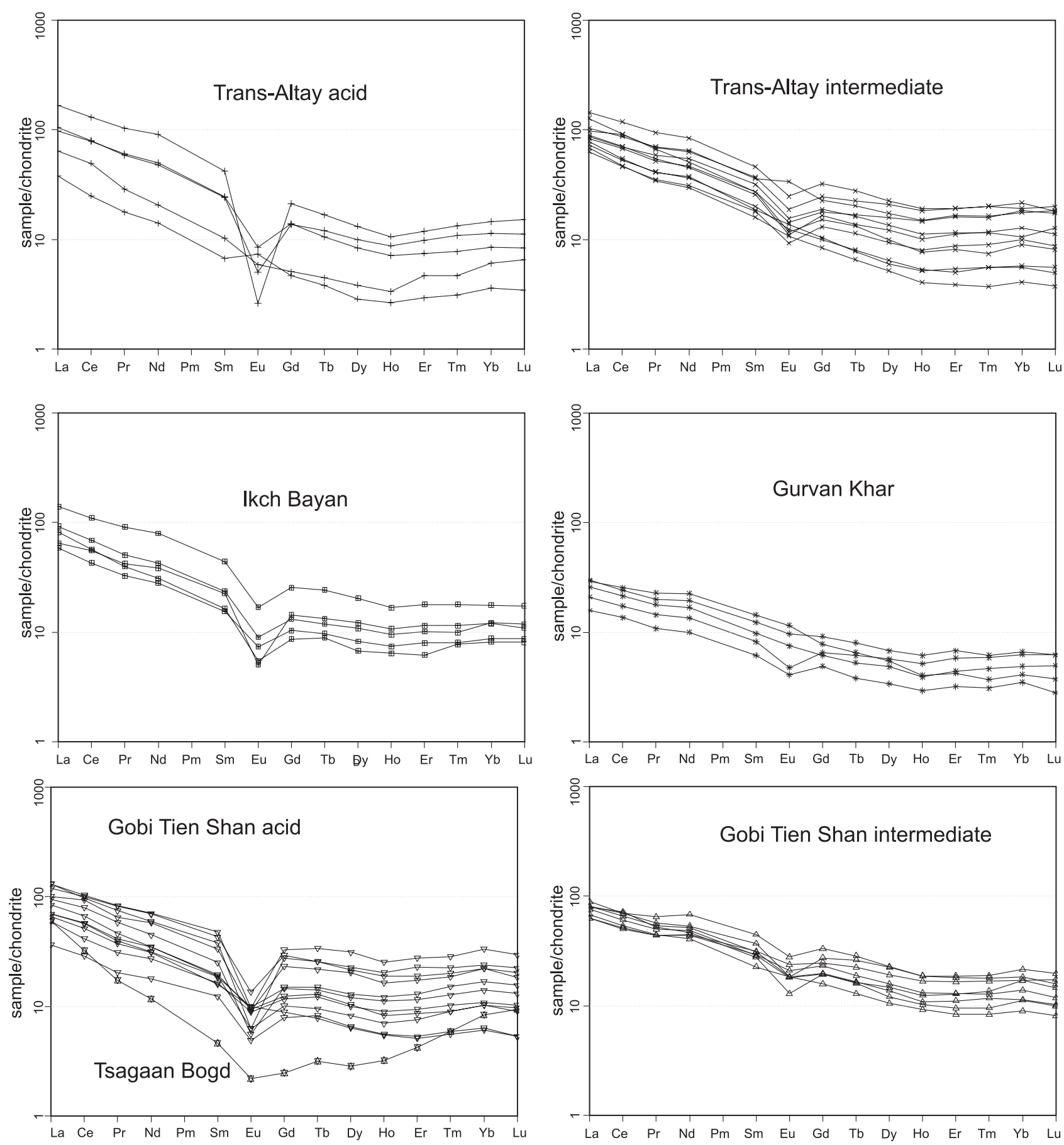

Fig. 9 Chondrite (Boynton 1984) normalized REE patterns for granitic rocks of the Trans-Altay Gobi.

intercept age of $263+14 /-13$ Ma can be derived from zircon analyses from sample A-26/1018; however, this date is likely to be biased towards younger ages by one discordant data point and it is therefore not considered as being very accurate. In summary, the age of magmatic activity in the Gobi Tien Shan area, as recorded by magmatic (euhedral and oscillatory-zoned) zircons extracted from nine granitic samples spans the time interval from
Early to Late Carboniferous, and perhaps even to Early Permian times.

A weighted mean ${ }^{238} \mathrm{U}-{ }^{206} \mathrm{~Pb}$ age of $330 \pm 12 \mathrm{Ma}$ and a corresponding lower concordia intercept age of $331 \pm$ 23 Ma can be derived from zircon analyses of the sample F-5/1020 representing granodiorite with granophyric texture of the Bayan Ayrag Massif in the Edrengiin Nuruu Mts. 

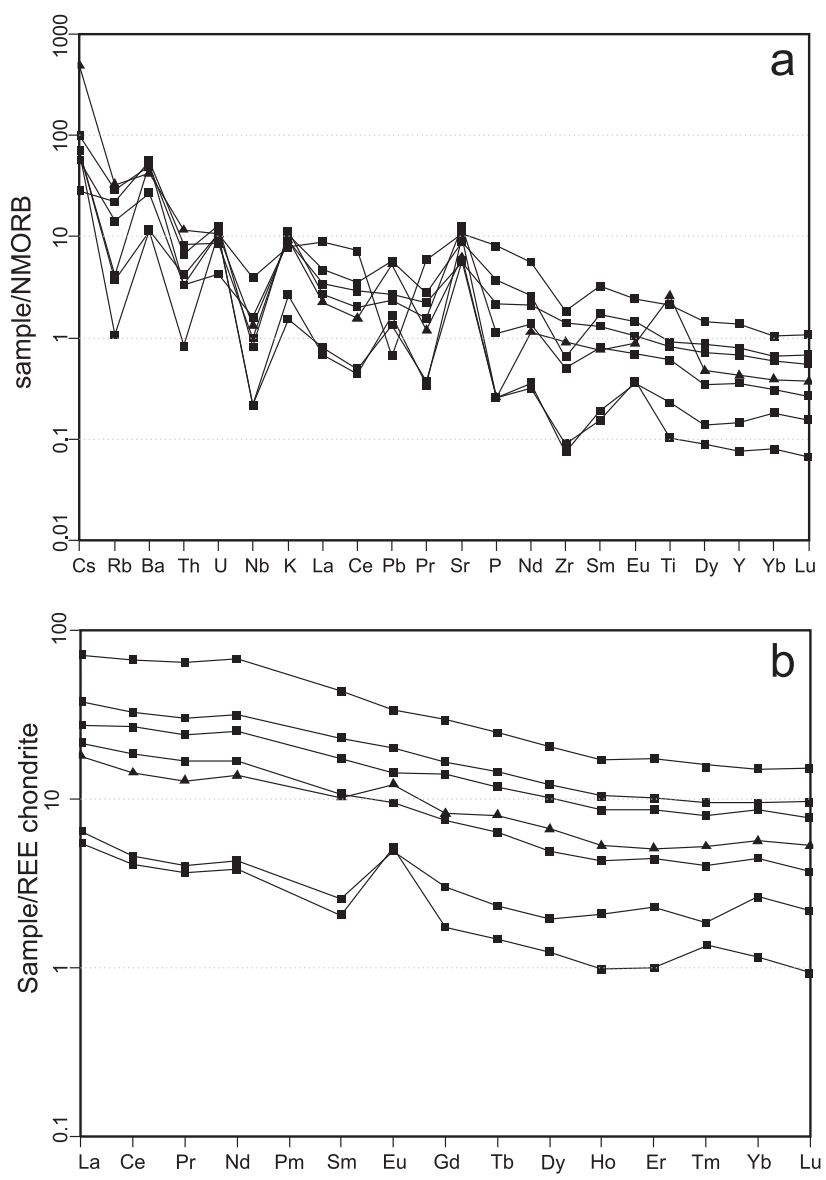

Fig. 10 Multielement trace-element patterns for gabbros of the TransAltay Gobi normalized by: a-NMORB (Sun and McDonough 1989); b - chondrite (Boynton 1984).

Two concordant data points in biotite granite sample C-28/1028 forming an independent body of Trans-Altay Intrusive Complex situated west of the Shar Khulsny Bulag in GTS gave Carboniferous concordia ages of 333 \pm 8 and $308 \pm 14 \mathrm{Ma}$. Both ages derived from euhedral magmatic zircons may be interpreted as either recording two separate phases of zircon crystallization from the magma, or as reflecting a prolonged phase of zircon magmatic crystallization during the Carboniferous period.

\section{Structures in granitic bodies}

Internal structures of plutonic rocks of the Trans-Altay Gobi have developed in a regime of the Variscan magmatic activity as well as during the postmagmatic deformation. Magmatic and late magmatic structures are characteristic of the largest body in the GTS, the Zamyn Belgekh Pluton, and are represented by magma mingling structures and magmatic foliation. Planes interpreted as magmatic foliation are sporadic only in the northernmost part of the Trans-Altay Intrusive Complex. The rocks of the Bayan Ayrag and Ikh Bayan massifs are usually without macroscopically observable magmatic structures. Post-magmatic structures are connected with the development of ductile to brittle-ductile foliation and brittle-ductile to brittle mylonitic zones, joint systems and the origin of tension joints that are filled with subvolcanic dykes. Late to post-magmatic foliation is characteristic of the NW part of the Zamyn Belgekh and Gurvan Khar massifs.

\subsection{Bayan Ayrag Massif}

Only the presence of fine-grained dark grey microdiorite enclaves could be described as magmatic fabric in the Bayan Ayrag Massif. Neither the magmatic foliations in intrusive rocks nor bedding in the wall-rock volcanic rocks have been found. Contacts of plutonites with their volcanic country rocks are fuzzy, granites intruded basalt and andesite in the form of dykes and loaf-shaped apophyses. Textures of a character transitional between plutonic and volcanic are developed in granites near the contacts with volcanic rocks.

\subsection{Trans-Altay Intrusive Complex}

Bodies of this complex are of oval or irregular shape. Country-rock xenoliths are exceptional. Magmatic to submagmatic foliation is very rarely developed in granodiorites of the Sayryn Pluton of the Trans-Altay Intrusive Complex. It is steep, NE-SW trending south of, and flat north of, the Trans-Altay shear zone. There is a very narrow or almost indistinct zone of thermal metamorphism around Trans-Altay granites. They intruded volcanic or volcaniclastic rocks usually without pronounced bedding. Transitional subvolcanic textures have locally developed along the contacts of granite apophyses with adjacent rhyolites. The contact has a clearly discordant character in places with preserved bedding. Rocks are mylonitized in exposures along the faults parallel with the Trans-Altay shear zone.

\subsection{The Ikh Bayan Massif}

Definitely post-orogenic are the circular intrusions of the Ikh Bayan Massif. A distinct contact aureole with thermally metamorphosed volcanosedimentary rocks has developed around intrusions, the bedding and cleavage in wall rocks are cut by granites. The plutonic bodies contain, particularly at their margins, wall-rock xenoliths of various sizes. The pronounced bending of the structural trends in adjacent geological units around the massifs, which is clear from the geological maps (see 

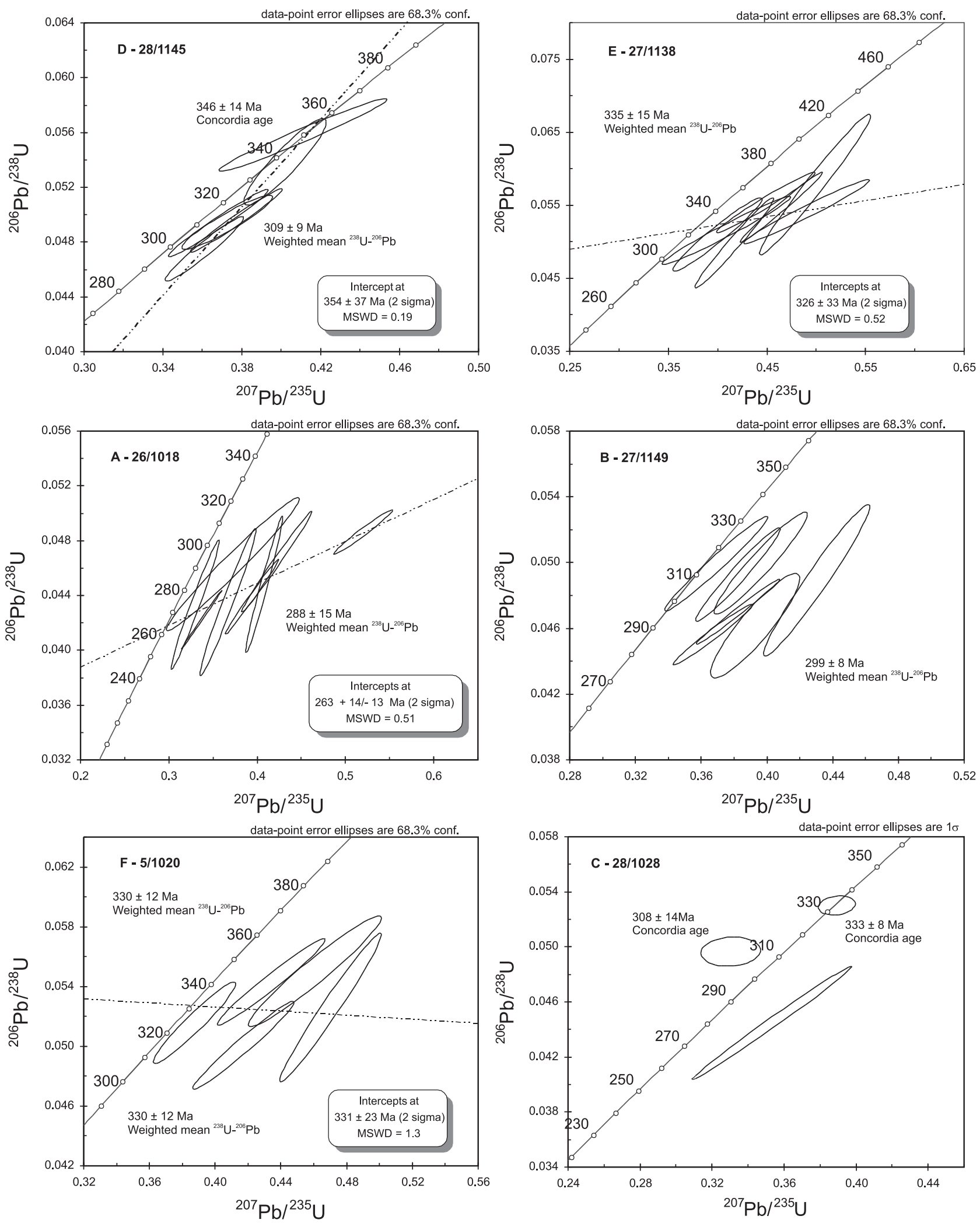

Fig. 11 U-Pb concordia diagrams for zircon LA ICP-MS analyses from the Zamyn Belgekh Pluton (samples A, B, D and E), granite from GTS corresponding to the Trans-Altay Intrusive Complex (sample C) and from Bayan Ayrag Massif (sample F). 
map enclosed in this Volume) as well as satellite images was caused by the post-magmatic deformation during the movements on the Trans-Altay shear zone.

\subsection{Gurvan Khar Massif}

Metamorphic foliation is developed solely in the rocks of the Gurvan Khar Massif. The foliations in recrystallized metagranodiorites and orthogneisses are of predominant NNW-SSE trend, with variable but usually subvertical dips. Such an orientation is subparallel with cleavage in the adjacent Early Carboniferous flysch sediments. The foliation trend is reoriented along the intrusions of the gabbro massifs to produce ring structures identifiable from the satellite images.

\subsection{Gobi Tien Shan Intrusive Complex}

Structures bound to the Gobi Tien Shan Intrusive Complex are best exposed in the granitoids of the Zamyn
Belgekh Pluton. Structures indicative of hybridization between granodiorites and diorite/gabbrodiorites are typical part of much of the massif. These structures (Fig. 5) are well exposed along the path between the Shar Khulsny and Zamyn Belgekh springs. Magma of granite-granodiorite composition was invaded by dioritic melt, forming syn-plutonic dykes which were often disintegrated into swarms of enclaves varying in size and degree of roundness. Basic enclaves are usually aligned in direction of the magmatic flow, flattened with varying intensity, thus defining magmatic foliation and lineation. Magmatic lineations are particularly highlighted by the preferred orientation of feldspars and hornblende grains. In the diorite body in the eastern part of the pluton, magmatic foliation is commonly defined by schlieren.

Strikes of magmatic foliation in the Zamyn Belgekh Pluton show predominant N-S to NE-SW orientations - closely resembling the foliation trends in the crystalline complex as well as bedding in country-rock sediments

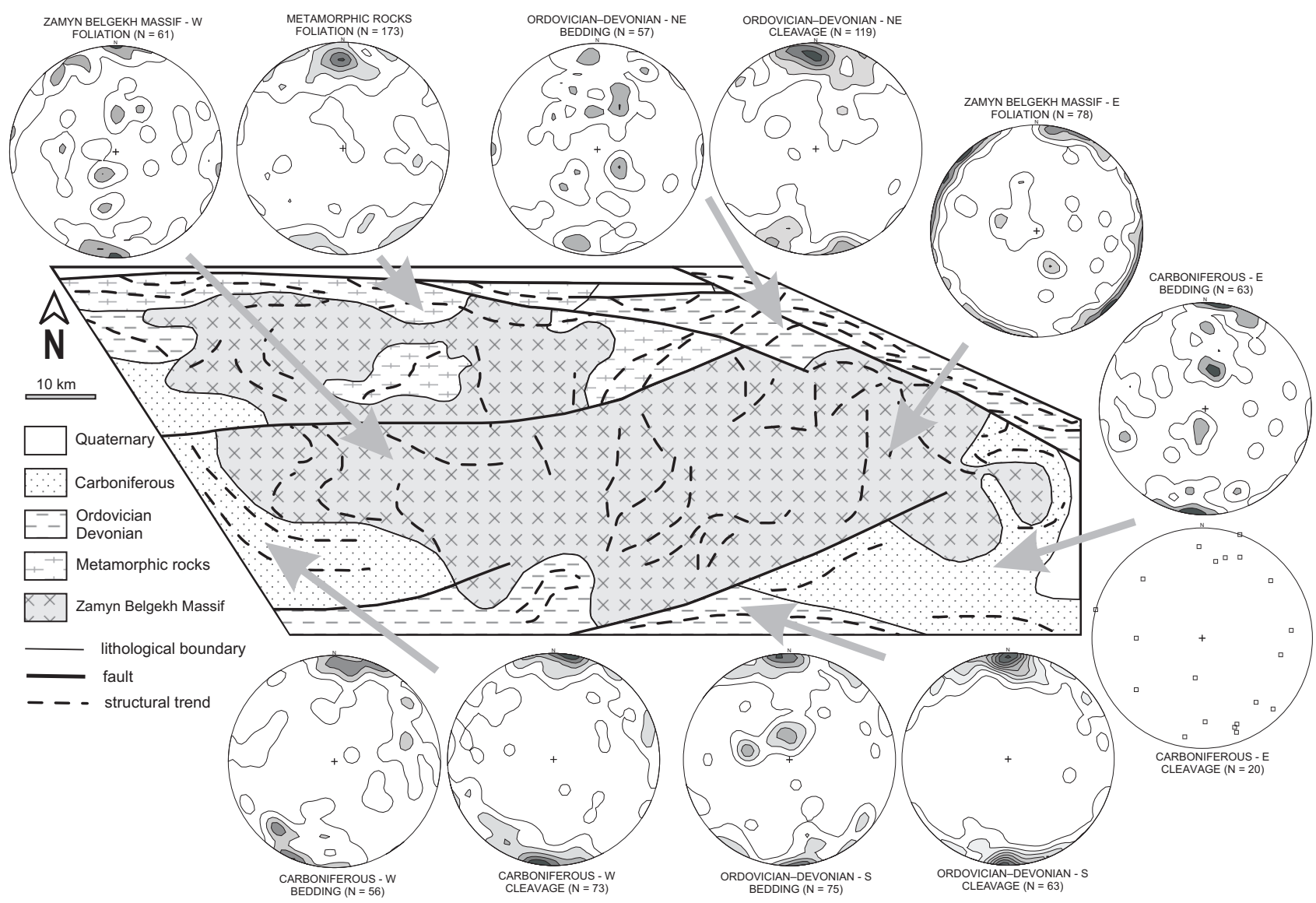

Fig. 12 Schematic map of the Zamyn Belgekh Pluton and contour diagrams summarizing orientation of planar structures in granites and adjacent rocks. Schmidt projection on the lower hemisphere. Step of contours 2 sigma. For position see Fig. 2. 
of the pluton (Fig. 12). Flat lying and NW-SE trending steep foliations are subordinate.

\section{Discussion}

The Trans-Altay Gobi is a part of the southern domain of Mongolia with accreted arc-related volcanic and volcaniclastic rocks (Lamb and Badarch 1997) of dominantly Silurian to Lower Devonian and Carboniferous to Permian ages. Wide compositional range, different structural features and irregular distribution of the Palaeozoic granitic intrusions reflect magmatic processes during accretion of separate domains of the Trans-Altay Gobi. Even though there exist differences in chemical composition among the individual Late Palaeozoic massifs in the Trans-Altay Gobi, they are all metaluminous and characterised by pronounced depletion in $\mathrm{Nb}, \mathrm{Ti}$ and $\mathrm{P}$, whereby the depletion in $\mathrm{Nb}$ and $\mathrm{Ti}$ is indicative of arc magmatism (Wilson 1989; Draut and Clift 2002). Luchitskaya and Tikhomirov (2007) described $\mathrm{Nb}$ and $\mathrm{P}$ minima in the Cretaceous subduction-related granitoids in the northeast Asia. Interpretation of the Trans-Altay Gobi granites as arc-related rocks is consistent with positions of the samples in the VAG field (Fig. 13) of geotectonic discrimination diagrams by Pearce et al. (1984). Relatively primitive geochemistry of granites is in accordance with the results of Jahn et al. (2000) and Jahn (2004) who emphasized juvenile character of granites in the Central Asian Orogenic Belt and short crustal residence since the separation of magmas from the source.

Although nearly all the plutons studied in the course of the present work are of igneous-arc character, there are several samples of granites from the Trans-Altay and Gobi Tien Shan Intrusive complexes indicating apparently an alkaline affinity (Fig. 14). These rocks are usually acid members of the individual intrusive complexes. Their geochemical signature resembling the intermediate members (Fig. 8) points rather to highly fractionated rocks of magmatic suites, especially in the Gobi Tien Shan Intrusive Complex.

Subvolcanic dyke rocks of bimodal composition are particularly associated with the Ikh Bayan Massif, Gobi Tien Shan Intrusive Complex and the Bayan Ayrag Massif. Their age is unknown. By analogy with the dated occurrences of similar rocks in NW China they can be connected to Permian post-collisional extension in the area (Zhang et al. 1998).

Pre-orogenic, syn-collisional and post-collisional plutonic bodies can be distinguished in relation to the accretionary processes culminating during the Late Carboniferous in the area of the Trans-Altay Gobi. The evolution of Early Carboniferous calc-alkaline granites
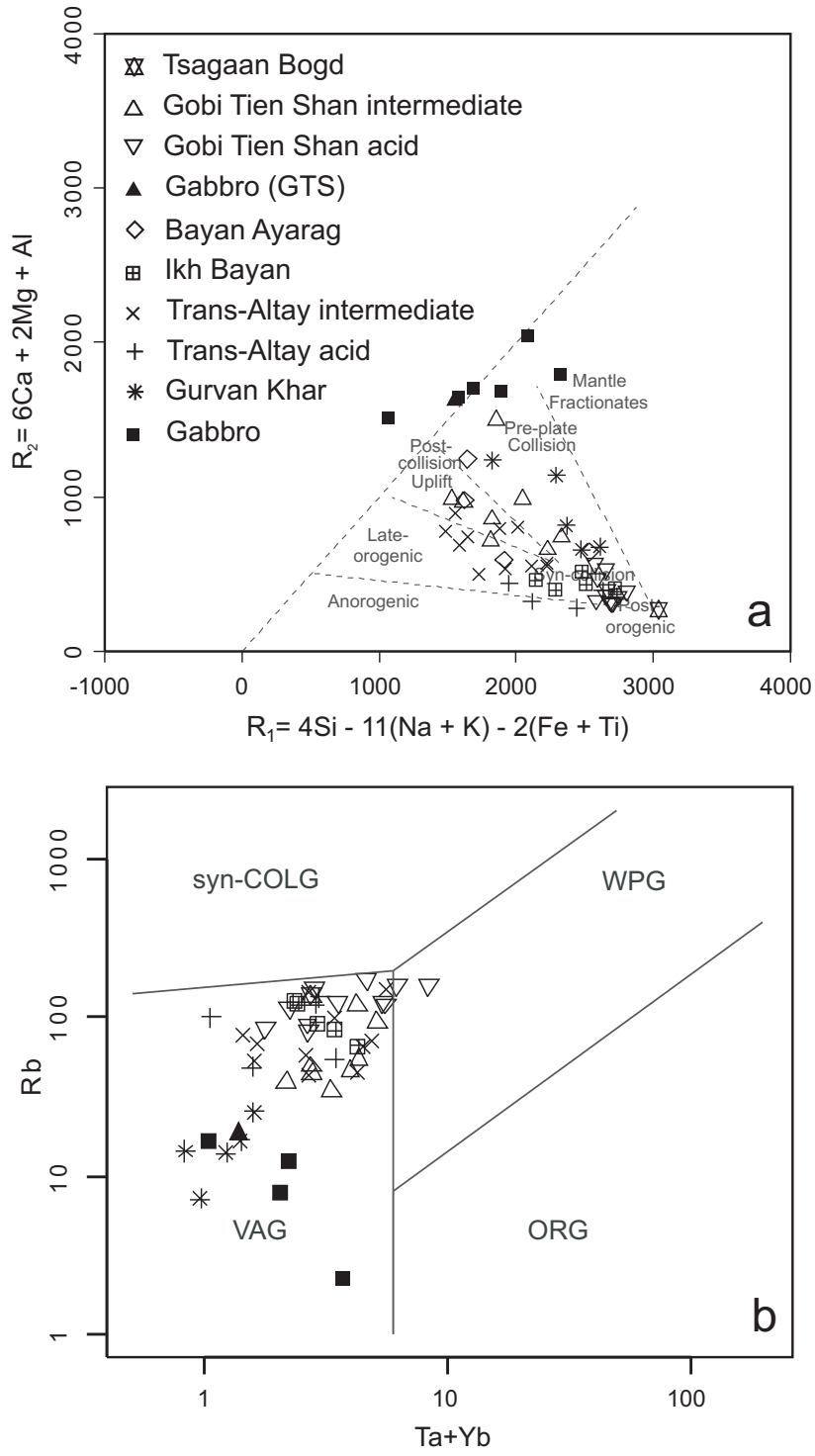

Fig. 13 Geotectonic discrimination diagrams for rocks of the TransAltay Gobi: $\mathbf{a}-\mathrm{R}_{1}-\mathrm{R}_{2}$ plot of Batchelor and Bowden (1985); $\mathbf{b}-\mathrm{Ta}+$ $\mathrm{Nb}$ vs. Rb diagram of Pearce et al. (1984). VAG - Volcanic Arc Granite, syn-COLG - syn-Collisional Granite, WPG - Within Plate Granite, ORG - Ocean Ridge Granite.

to Late Carboniferous/Permian high-K rocks in time and similar trend in space from the south to the north indicate the presence of a Carboniferous subduction zone dipping north and situated south (in relation to present-day coordinates) of the Gobi Tien Shan Domain. The final closure took place most likely during the Upper Carboniferous and Permian. Such a scenario is in accord with palaeotectonic interpretations in the southern Mongolia (Ruzhentsev and Pospelov 1992; Windley et al. 2007) as well as the Chinese Tien Shan (Windley et al. 1990; Allen et al. 1992; Xiao et al. 2004). 

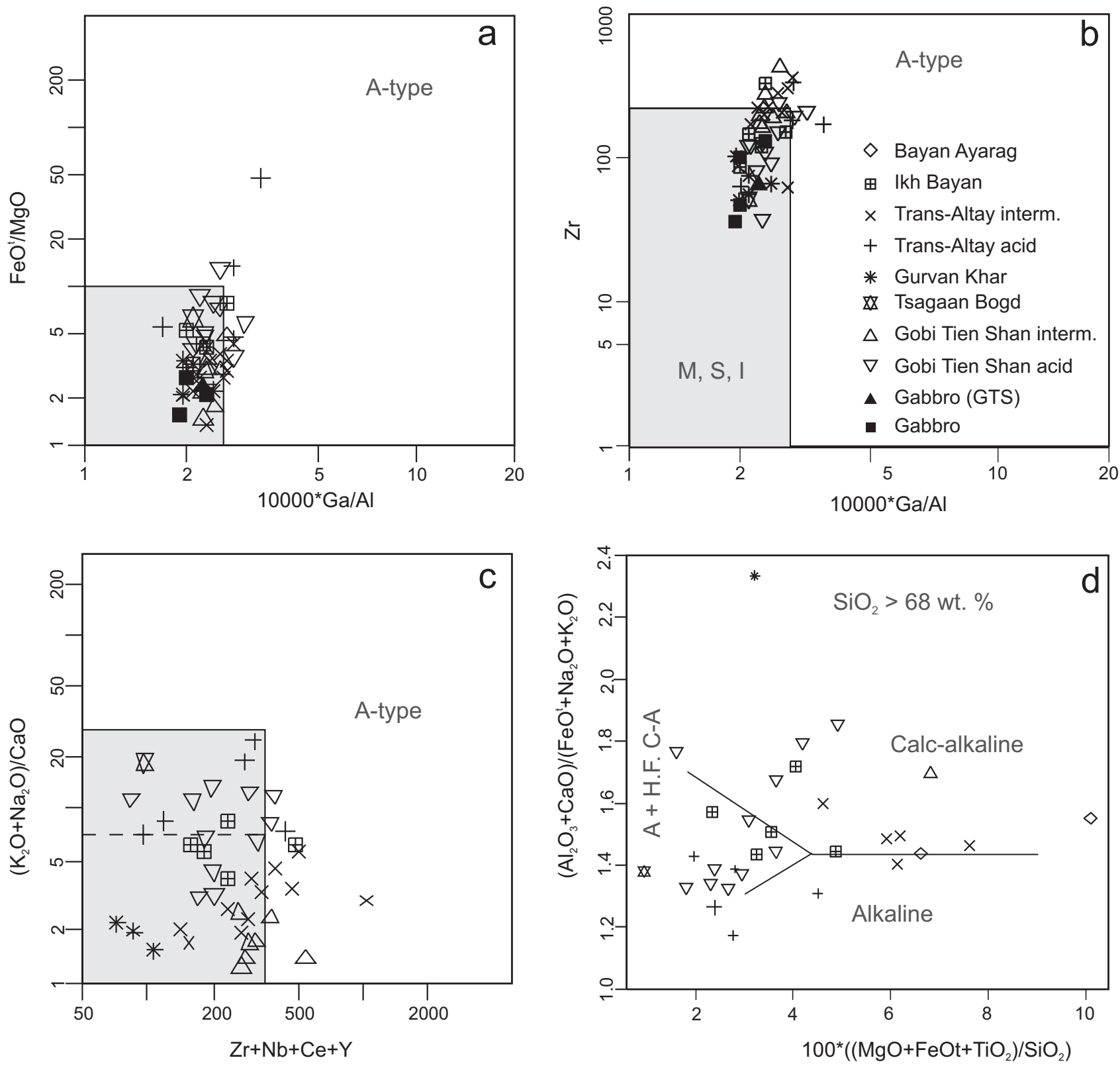

Fig. 14 Position of granitic samples in A-type granite discrimination diagrams: a, b-1000* $\mathrm{Ga} / \mathrm{Al}$ vs. $\mathrm{FeO} / \mathrm{MgO}$ resp. $\mathrm{Zr}$ diagrams (Whalen et al. $1987) ; \mathbf{c}-\mathrm{Zr}+\mathrm{Nb}+\mathrm{Ce}+\mathrm{Y}$ vs. $\left(\mathrm{K}_{2} \mathrm{O} / \mathrm{Na}_{2} \mathrm{O}\right) / \mathrm{CaO}$ (Eby 1990); d - classification diagram $100 *\left(\left(\mathrm{MgO}+\mathrm{FeO}^{\mathrm{t}}+\mathrm{TiO}_{2}\right) / \mathrm{SiO}_{2}\right) \mathrm{vs} .\left(\mathrm{Al}_{2} \mathrm{O}_{3}+\mathrm{CaO}\right) /(\mathrm{FeO}$ $+\mathrm{Na}_{2} \mathrm{O}+\mathrm{K}_{2} \mathrm{O}$ ) (Sylvester 1989). Explanations: M, S, I - field of M, S and I type granites; A + H.F. CA - alkaline and highly fractionated calcalkaline granites.

\subsection{Pre-tectonic igneous activity}

Only the Gurvan Khar Massif can be assumed as being a pre-tectonic granite body in relation to Variscan orogeny in the area. It was incorporated into the geological structures of the adjacent rocks by post-magmatic tectonometamorphic processes. Metagranodiorites and orthogneisses representing this massif are exposed in tectonic slices within the Palaeozoic volcaniclastic sediments of the Baytag Terrane along the boundary between the SG and TA domains. Long axes of tectonic slices are subparallel with structural trends in adjacent volcaniclastic sequences and rocks are usually mylonitized in the fault zones along the contacts of geological formations. In the less affected parts of the massif, metamorphic foliation developed due to the recrystallization of quartz, feldspars and biotite. The massif was intruded by oval bodies of gabbro and cut by dykes of massive red granites corresponding to rocks of the Trans-Altay Intrusive Complex. Trends of foliation are subparal- 
lel with cleavage in the adjacent Late Devonian-Early Carboniferous flysch sediments (Fig. 15). Interpretation of the post-magmatic relationships between metagranodiorites and flysch is complicated by the development of a thermal metamorphic aureole. Indeed this aureole could be related to intrusions of the oval-shaped gabbro massifs, around which circular structures with bending of foliation have formed especially north of the Gurvan Khar Mt.

Deformed granitoids of the massif differ chemically from the other granitic rocks in the area. They are characterised by very low contents of $\mathrm{K}_{2} \mathrm{O}$, corresponding to tholeiitic rocks. The low $\mathrm{K}_{2} \mathrm{O} / \mathrm{Na}_{2} \mathrm{O}$ and $\mathrm{Rb} / \mathrm{Sr}$ ratios point, together with the very low degree of fractionation of REE, to a primitive source of parental magmas. High and variable $\mathrm{K} / \mathrm{Rb}$ ratios with weak enrichment in $\mathrm{U}$, $\mathrm{Ba}$ and $\mathrm{Pb}$ can indicate mobility of elements during the metamorphism and deformation.

The primitive chemical features of the rocks, position of samples in Pre-plate Collision Field of the $R_{1}-R_{2}$ diagram (Batchelor and Bowden 1985, Fig. 13a) imply a largely different character in comparison with other granitic bodies of the Trans-Altay Gobi. Even though there are no geochronological data available except for the unpublished Early Devonian zircon age obtained by Kröner (Šourek et al. 2003), geological and structural data can indicate older than Carboniferous age. The rock chemistry points to an evolution in a primitive magmatic arc. This is in agreement with geological position of the Gurvan Khar Massif which is bounded to the zone situated along the suture between Bayatag and Baaran terranes. It is marked by relics of Ordovician-Devonian (Ruzhentsev 1985; Ruzhentsev et al. 1985), tectonic mélange with deep water sediments, pillow lavas and fragments of serpentinites exposed in a narrow structure known as the Zoolen accretionary prism Terrane (Badarch et al. 2002). On the other hand, Helo et al. (2006) interpreted eastern exposures of this terrane as single intra-oceanic island arc-forearc according to geochemical characteristics. The U-Pb SHRIMP single zircon dating of metavolcaniclastic rocks from eastern part of the Zoolen Terrane gave ages of $421 \pm 3 \mathrm{Ma}$ and $417 \pm 2.2 \mathrm{Ma}$ (Helo et al. 2006). These data may support the presumed Devonian age of the Gurvan Khar Massif.

\subsection{Syn-collisional plutonism}

The Gobi Tien Shan Intrusive Complex is represented by numerous bodies forming an E-W trending belt between the Gobi Tien Shan fault zone in the north and the Mongolia-China border in the south. The Zamyn Belgekh Pluton in the western part of Gobi Tien Shan range is the largest body among them. It is a composite pluton with newly-established intrusion age of 355-310
Ma corresponding to the Carboniferous. Permian ages of about 260-290 Ma can be related to a younger magmatic phase. Monzodiorites to diorites which form relatively independent bodies in the $\mathrm{N}$ and NE parts of the Zamyn Belgekh Pluton are its relatively oldest facies. In the main body of the pluton, predominant granodiorites to granites had been intruded by biotite-hornblende diorites, while still (largely) molten, giving rise to magma mingling textures. Magmatic foliation developed in the intermediate members shows a weak preferred orientation but the maxima in structural contour diagrams correlate well with the bedding orientation in Silurian-Devonian as well as Carboniferous sediments preserved as a roof pendants of the pluton (Fig. 12). The magmatic foliation was reoriented to a prevailing $\mathrm{E}-\mathrm{W}$ trend along the $\mathrm{N}$ margin of the pluton and corresponds with metamorphic foliation within the rocks of the Atas Uul-Tchinges Uul mountain range. The ellipsoidal structural trends in thermally metamorphosed wall rocks, structures indicative of magmatic flow in the western part of pluton, submagmatic deformation along the northern endocontact and the oval-shaped, relatively separate intrusion in the east part of the pluton, which are well visible from the geological maps and satellite imagery indicate as the dominating mechanism of intrusion. It was combined with magma stoping processes as proved by the occurrence of the common septa in NW part of pluton.

Erosional processes have exposed deeper facies of the massif, connected with more intense thermal metamorphism in the N and NW. Granites without preserved magmatic fabrics and granophyric granites are typical of the central and SE parts of the pluton. The presence of granophyric textures in the granites and very narrow contact aureole point to a intrusion level with the pressure of up to $5 \mathrm{kbar}$. Cordierite and andalusite in the contact zone indicate temperatures of $500-600{ }^{\circ} \mathrm{C}$ (Bucher and Frey 1994) in the SE part of pluton, while garnet-biotite thermometer in migmatized gneiss xenolith in diorites in NE part points to temperatures $680{ }^{\circ} \mathrm{C}$, possibly reflecting the higher temperature of the dioritic magma. Granophyric granites passing to granites with corroded quartz and feldspars phenocrysts in granophyric matrix are exposed commonly close to the Carboniferous volcanic rocks in the roof pendant of the pluton, which points to comagmatic evolution during the youngest phases of the pluton evolution. The granophyric granites probably correspond to the apical part of the intrusion, which, rich in fluids, intruded in subvolcanic conditions.

Plutonic rocks of the GTS have an I-type character corresponding to the volcanic arc-granites according to Pearce et al. (1984). Nevertheless, the chemical composition of rocks indicates - in accordance with structural features - two different rock groups. The intermediate rocks are calc-alkaline with low $\mathrm{Rb} / \mathrm{Sr}$ ratios, correspond- 
ing to Syn-Collisional to Post-Collisional Uplift field of the $R_{1}-R_{2}$ diagram (Fig. 13a), seem to be related to earlier stages of the igneous-arc evolution. Acid rocks usually without internal fabric are high-K calc-alkaline. Higher and variable $\mathrm{K}_{2} \mathrm{O} / \mathrm{Na}_{2} \mathrm{O}$ and $\mathrm{Rb} / \mathrm{Sr}$ ratios point to more evolved source and/or contamination during the ascent. These rocks are of distinctly post-collision character as seen from the $\mathrm{R}_{1}-\mathrm{R}_{2}$ diagram.

Linear arrangement of plutonic bodies of the Gobi Tien Shan indicates development of intrusive rocks at an Andean-type continental margin. Geological relationships, petrography and geochemical data in the Zamyn Belgekh Pluton suggest following stages in evolution during the Early Carboniferous:

- generation of basic magma above the subduction zone and its ascent,

- melting of overlying rocks in the igneous arc triggered by basic magma emplacement,

- generation and segregation of the granitic magma, processes of mixing with underlying basic magma and construction of the batholith,

- emplacement of granophyric granites accompanied by subaerial volcanic activity.

\subsection{Post-collisional bodies}

Post-tectonic intrusive bodies should cut both the bedding and metamorphic fabric in their country rocks (Clarke 1992). The oval bodies of the Trans-Altay Intrusive Complex, circular intrusions of Ikh Bayan and the Bayan Ayrag massifs indeed penetrate Variscan geological structures in the Trans-Altay Gobi. They usually have no visible internal fabric and could be interpreted as posttectonic massifs. This also concerns some small bodies of granites in the Gobi Tien Shan Domain. Even though all these massifs are of post-collisional character, they differ in some features.

The only one sample from the Tsagaan Bogd Massif is not possible to interpret. Moreover, unusual REE trend points to late- or post-magmatic alteration.

Bayan Ayrag Massif crops out in the NE part of studied region in the Edren Terrane. Its high-K calc-alkaline granites are of Early Carboniferous age according to zircon dating $(330 \mathrm{Ma})$. They are comagmatic with bimodal Carboniferous volcanics.

The circular bodies of the Ikh Bayan Massif are clearly post-collisional. Their exposures rim the suture zone between the Baaran and Baytag terranes. The geochemical composition is typical of high-K, I-type granites. The higher $\mathrm{K} / \mathrm{Rb}$ and lower $\mathrm{Rb} / \mathrm{Sr}$ ratios are similar to values in the Trans-Altay granites. They correspond to volcanic arc granites sensu Pearce et al. (1984) and fit the field of Syn-Collision Granites in the $\mathrm{R}_{1}-\mathrm{R}_{2}$ diagram (Fig. 13). Circular shape and regular zoning of the thermal meta- morphism suggest ballooning as a possible mechanism of intrusion. No radiometric data are available but a distinct contact aureole has developed in the Devonian and Lower Carboniferous rocks around the massif indicating its Early Carboniferous-Permian age. As there are no radiometric data confirming the Permian intrusive age in the Trans-Altay Gobi, this age is documented by Lamb et al. (2008) from granites in the Shinjinst area of the Gobi Altay range NE of the studied area. Also Kovalenko et al. (2006) described the Permian Khan Bogd alkali granite pluton in the Gobi Tien Shan Rift Zone E of the TransAltay Gobi area.

In the map sheet area, isolated bodies which are related to the Trans-Altay Gobi Intrusive Complex occur both in the Trans-Altay and Shargyn Gobi terranes. Similar granites forming the Gobi Tien Shan Terrane have a slightly different chemistry and the question of their mutual relationships remains still open. In the studied region, the majority of individual plutons are situated in the Shargyn Gobi Domain. The plutons cut palaeontologically dated Lower Carboniferous volcaniclastic sequences north of the Shargyn Gobi intermountain depression. Microdiorite enclaves are rare and wall-rock xenoliths are usually absent in these rocks. The Late Carboniferous age of the massif is also confirmed by radiometric dating (sample C in Fig. 11), but the number of dated zircons is too low for relevant interpretation. Rocks are of I-type; relatively primitive source is confirmed by high $\mathrm{K} / \mathrm{Rb}$ and low $\mathrm{Rb} / \mathrm{Sr}$ ratios. On the other hand, high-K calc-alkaline character, fractionated REE trends and enrichment in $\mathrm{Rb}$, $\mathrm{Th}$ and $\mathrm{Pb}$ in the NMORB-normalized spiderplots could indicate contamination by crustal material. The rocks are of Volcanic-Arc Granite type according to Pearce et al. (1984) and show a trend from Late- to Post-orogenic Granites in the $\mathrm{R}_{1}-\mathrm{R}_{2}$ diagram. The low $\mathrm{Ba}, \mathrm{Sr}$ and $\mathrm{Eu}$ abundances corresponding to a post-orogenic granite (Bonin et al. 1998) can be related with extensive fractionation of feldspars.

Geochemistry of a few samples (Fig. 14) and textures with K-feldspar laths and amphibole can indicate alkaline affinity of some isolated bodies of the Trans-Altay Intrusive Complex and also of the Bayan Ayrag Massif. These massifs are related with the Carboniferous to Permian volcanic rocks of alkaline character (Yarmolyuk 1983). The best example is the NW-SE elongated red granite pluton NW of the Arslan Khayrkhan Mt. in the Baytag Terrane. Alternation of ring-like parts of the granitic massif with acid volcanics and transition between granitic and volcanic textures in adjacent rocks could indicate cauldron subsidence as a key emplacement process.

Small gabbro massifs seem to be the youngest intrusive rocks in the Trans-Altay Gobi. They are preferentially distributed close to the oval-shaped intrusions of 


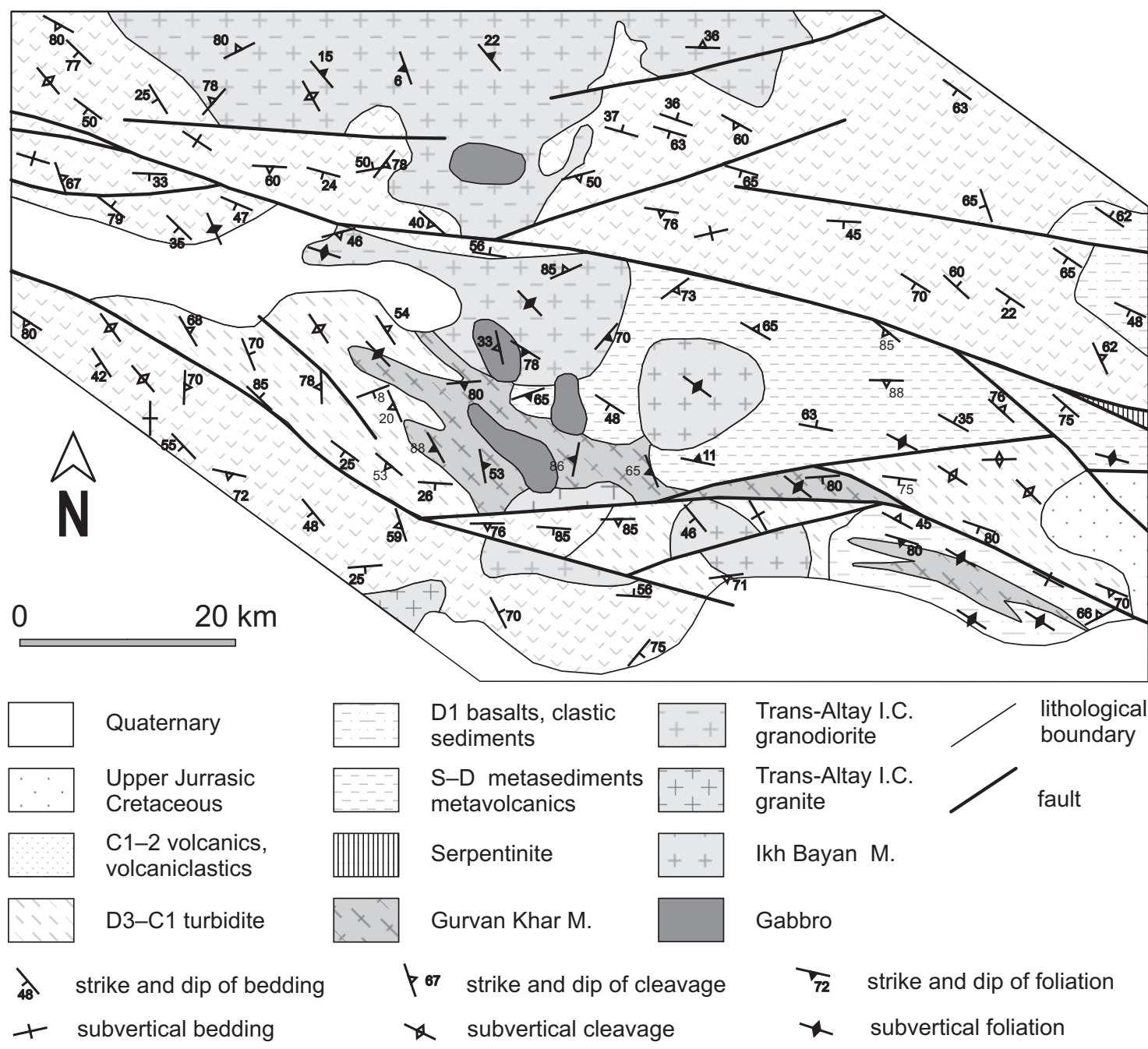

Fig. 15 Schematic structural map along the Trans-Altay shear zone north of the Gurvan Khar Mt. For position see Fig. 2.

the Ikh Bayan Massif north of Gurvan Khar Mt. Invasion of gabbros into the granitoids caused probably partial remobilisation of the granitic melt and netveining of the gabbros by the granitic melt (Fig. 15).

\subsection{Trans-Altay shear zone}

The NW-SE oriented zone separating the Baytag and Baaran terranes is marked by a mylonitic zone, ultrabasic bodies, alternation of tectonic slices with rocks from both of the terranes, relics of Triassic sediments and granite bodies of the Ikh Bayan Massif. It corresponds with a suture separating Baytag and Baaran terranes, in which relics of ophiolites are preserved (Zoolen Terrane) more to the SE. Regional structural trends are markedly bent around circular granite bodies. This is apparent from the satellite images, geological maps, and also confirmed by orientation of small-scale structures (Fig. 15). The geometry of regional structures corresponds to sigma porphyroclasts (Passchier and Simpson 1986; Hanmer 1990) used as a shear-sense indicator. Granite massif in the centre seems to have behaved as a rotated rigid block during the movements between the terranes. Bedding and cleavage in adjacent volcaniclastic formations was bent during rotation of the Ikh Bayan Massif caused by strikeslip movements on the zone. Asymmetric geometry of the described structures indicates dextral sense of movement along the Trans-Altay shear zone. The location of gabbros in the areas of pressure shadows behind the rotated massifs suggests syn-tectonic formation contemporaneous with the movements on this shear zone.

As bodies of the Trans-Altay Intrusive Complex are exposed on both sides of the Trans-Altay shear zone (Fig. 1), they might have post-dated the movements on this zone. The zone was reactivated during the Cenozoic movements on the Gobi Tien Shan fault (Tapponier and Molnar 1979; Cunningham et al. 1996) but its formation is probably older because of similar shear zones have 
been described and dated from the Chinese and Kazakhstan parts of Central Asian Orogenic Belt. Allen et al. (1992) depicted post-collisional but Palaeozoic (Late Carboniferous-Early Permian), dextral shear zone accompanied by the intrusion of basic and acid magmas in the northern suture of the Chinese Tien Shan. Early Permian age for the dextral motion on the Tien Shan Shear zone (Shu et al. 1999) is confirmed by dating of newly formed muscovite in dextrally sheared mylonite.

A tectonic feature, which can be geographically linked with the Trans-Altay shear zone, is a $5-10 \mathrm{~km}$ wide sinistral NW-SE trending Erqishi shear zone (LaurentCharvet et al. 2002), known also as Ertix fault (Briggs et al. 2007). It stretches from Qinhe in the Chinese Altay to Kazakhstan, where it is named the Irtysh shear zone (Melnikov et al. 1997). In Kazakhstan, the initiation of this shear zone occurred about $290 \mathrm{Ma}$ ago as determined from ${ }^{40} \mathrm{Ar} /{ }^{39} \mathrm{Ar}$ mica dating in syn-tectonic granite (Melnikov et al. 1998). The main movement was sinistral and occurred along the Erqishi zone between 280-290 Ma. It was followed by a complex succession of dextral and sinistral shearing episodes dated at $245 \mathrm{Ma}$ (LaurentCharvet et al. 2003).

\section{Conclusions}

The Trans-Altay Gobi, as a part of the Central Asian Orogenic Belt consolidated during the Carboniferous, is composed of the Trans-Altay, Shargyn Gobi and Gobi Tien Shan domains which are constituted by individual (sub)terranes. All these were intruded by numerous pre-orogenic to post-orogenic granitic bodies of Devonian to Permian ages. Plutons are I-type, calc-alkaline, exceptionally with alkaline affinity of some acid rocks. They thus were most likely derived in a Late Palaeozoic volcanic arc related to the north-dipping Carboniferous subduction zone situated further south (in the present-day coordinates). According to geological position, six granitic intrusive complexes and independent gabbro massifs have been distinguished. These are, going generally from north to south:

- The Early Carboniferous Bayan Ayrag Massif in the Edren Terrane which is of post-orogenic character and comagmatic with the adjacent bimodal volcanics.

- The Trans-Altay Intrusive Complex is of Carboniferous to probably Permian age. Individual plutons are scattered throughout all terranes but the largest ones are bound mostly to the Shargyn Gobi and Trans-Altay domains. Intermediate to acid magmatic suites can be recognized. They are usually high-K calc-alkaline, highly fractionated rocks, with a signature resembling some individual plutons of alkaline affinity in Shargyn Gobi.

- The Carboniferous to Permian(?) Ikh Bayan Massif intruded along the Trans-Altay shear zone in the form of conspicuously circular plutons of a purely granitic composition.

- The Gurvan Khar Massif is probably of Devonian age, being composed of granodioritic orthogneiss. Geological relationships and primitive chemistry with very low-K character suggest evolution in an oceanicisland or primitive island-arc environment and could be related to ophiolite remnants in the Zoolen Terrane exposed in the suture between Trans-Altay and Shargyn Gobi domains.

- The Gobi Tien Shan Intrusive Complex is represented by numerous plutonic bodies in the Gobi Tien Shan range intruding accreted Ordovician to Carboniferous volcaniclastic complexes. In the NW part of the mountain range it also cuts metamorphic rocks of unknown age. Three magmatic suites have been recognized forming a gabbro - diorite - quartz diorite to monzodiorite - granodiorite - granite sequence. According to laser ablation ICP-MS data, the largest body of the complex - the Zamyn Belgekh Pluton - is Carboniferous. Nevertheless, Permian magmatic activity was documented in two samples. Magma mingling structures between basic and intermediate/acid magmas are characteristic of the magmatic complex and, together with I-type chemistry, point to an evolution above a subduction zone. Close spatial relations with the Carboniferous volcanics, granophyric textures in granites and mineral association in thermally metamorphosed rocks around the pluton point to an intrusion into the upper crustal level. Small bodies of the Naran Sevest and Tsagaan Bogd massifs represent relatively independent facies of the Gobi Tien Shan Intrusive Complex.

- Gabbro massifs of clearly post-orogenic character in respect to the Variscan accretion are closely related to the Late Carboniferous-Permian dextral shearing on the Trans-Altay shear zone separating Shargyn Gobi and Trans-Altay domains.

Acknowledgements. This study was based on data collected during the project "Geological and Geochemical mapping of Trans-Altay Gobi". It was prepared by Geomin Co., Jihlava in cooperation with Mineral Resources Authority of Mongolia within the framework of the International Cooperation Program of the Czech Republic in 1999-2003. The primary results including geological maps on a scale of $1: 200,000$ are available in Geological Information Centre in Ulaanbaatar. We are grateful to colleagues from the Mongolian Geological Survey and Mongolian University of Science and Technology who helped us with the field work as well as with the processing of maps. We are grateful to the staff of the expedition, above all to the excellent Mongolian drivers and especially we thank to J. G. Holák 
for his logistic support in the field. Comments by I. Petrík, an anonymous reviewer and handling editor M. Štemprok have significantly helped us to improve this manuscript. We are also indebted to V. Janoušek for help with the preparation of the final version of manuscript.

Electronic supplementary material. The tables 4 and 5, as well as GPS coordinates of the studied samples, are available online at the Journal web site (http://dx.doi. org/10.3190/jgeosci.028).

\section{References}

Allen MB, Windley BF, Zhang C (1992) Paleozoic collisional tectonics and magmatism of the Chinese Tienshan, central Asia. Tectonophysics 220: 89-115

Badarch G, Cunningham WD, Windley BF (2002) A new terrane subdivision for Mongolia: implications for the Phanerozoic crustal growth of central Asia. J Asian Earth Sci 21: 87-110

BAtChelor RA, Bowden P (1985) Petrogenetic interpretation of granitoid rock series using multicationic parameters. Chem Geol 48: 43-56

Batulzi D, Hanžl P, Orolzodmaa O, Naranbaatar TS (2003) Chemistry of the Carboniferous batholite Zambilgekh in Trans Altai Region. Mongol Geosci 21: 57-60

Bibikova EV, Kirnozova TI, Kozakov IK, Kotov AB, Neymark LA, Gorokhovskiy BM, Shuleshro IK (1992) $\mathrm{U}-\mathrm{Pb}$ ages for polymetamorphic complexes on the southern flank of the Mongolian and Gobi Altai. Geotectonics 26: $166-172$

Bonin B, Azzouni-Sekkal A, Bussy F, Ferrag S (1998) Alkali-calcic and alkaline post-orogenic (PO) granite magmatism: petrologic constraints and geodynamic settings. Lithos 45: 45-70

Borzakovskit YA, Suprunov EA (1990) Geological and mineral resources maps of western Mongolia on scale $1: 500,000$ with explanatory notes. Geological Information Centre, Mongolia, File Report no. 4496, Ulaanbaatar (in Russian)

Boynton WV (1984) Cosmochemistry of the rare earth elements: meteorite studies. In: HENDERSON PE (ed) Rare Earth Element Geochemistry. Elsevier, Amsterdam, pp 63-114

Briggs SM, Yin A, Manning CE, Chen ZL, Wang XF, Grove M (2007) Late Paleozoic tectonic history of the Ertix fault in the Chinese Altai and its implications for the development of the Central Asian Orogenic System. Geol Soc Am Bull 119: 944-960

Bucher K, Frey M (1994) Petrogenesis of Metamorphic Rocks. Springer-Verlag, Berlin, pp 1-318

Clarke DB (1992) Granitoid Rocks. Chapman \& Hall, London, pp 1-283
Cunningham WD, Windley BF, Dorjnamuaa D, BadamgaROV J, SAANDAR M (1996) Late Cenozoic transpression in southwestern Mongolia and the Gobi Altai-Tien Shan connection. Earth Planet Sci Lett 140: 67-81

Draut AE, Clift PD (2002) The origin and significance of the Delaney Dome Formation, Connemara, Ireland. J Geol Soc, London 159: 95-103

EBy GN (1990) The A-type granitoids: a review of their occurrence and chemical characteristics and speculations on their petrogenesis. Lithos 26: 115-134

FERRY JM, SPEAR FS (1978) Experimental calibration of the partitioning of $\mathrm{Fe}$ and $\mathrm{Mg}$ between biotite and garnet. Contrib Mineral Petrol 66: 113-117

Filippova IV, Suetenko OD, Levintov ME (1990a) Explanation text to Geological map of Western Mongolia on the scale $1: 500,000$. Volume 1 Stratigraphy, AN SSSR, Moscow (in Russian)

Filippova IV, Suetenko OD, Levintov ME (1990b) Geological map of Western Mongolia on the scale 1:500,000. AN SSSR, Moscow (in Russian)

HanŽL P, KREJČÍ Z eds (2008): Geological map of the Trans-Altay Gobi 1 : 500,000. Czech Geological Survey, Prague

Hanžl P, Otava J, Rejchrt M, Naranbaatar D, Coggerel J, Bajanjargal B, Lexa O, Černý M (2003) Geology of the Trans-Altai Gobi, SW Mongolia. J Czech Geol Soc 48: $55-56$

HANMER S (1990) Natural rotated inclusions in non-ideal shear. Tectonophysics 176: 245-255

Helo C, Hegner E, Kröner A, Badarch G, Tomurtogoo O, Windley BF, Dulski P (2006) Chemical signature of Paleozoic accretionary complexes of Central Asian Orogenic Belt in South Mongolia: constraints on arc environments and crustal growth. Chem Geol 227: 236-257

Hendrix MS, Graham SS, Carroll AR, Sobel ER, Mc Knight CL, Schulein BJ, Wang Z (1992) Sedimentary record and climatic implications of recurrent deformation in the Tianshan: evidence from Mesozoic strata of the north Tarim, south Junggar and Turpan basins, northwest China. Geol Soc Am Bull 104: 53-79

Holland T, Blundy J (1994) Non-ideal interactions in calcite amphiboles and their bearing on amphibole-plagioclase thermometry. Contrib Mineral Petrol 116: 433-447

Holland TJB, Powell R (1985) An internally consistent thermodynamic dataset with uncertainties and correlations: 2. Data and results. J Metamorph Geol 3: 343-370

Holland TJB, Powell R (1998) An internally consistent thermodynamic data set for phases of petrological interest. J Metamorph Geol 16: 309-343

Hu A, Jahn BM, Zhang G, Chen Y, Zhang Q (2000) Crustal evolution and Phanerozoic crustal growth in northern Xinjiang: Nd isotopic evidence. Part 1. Isotopic characterization of basement rocks. Tectonophysics 328: 15-51 
JAHN BE (2004) The Central Asian Orogenic Belt and growth of the continental crust in the Phanerozoic. In: Malpas J, Fletcher CJN, Ali JR, Aitchinson JC (eds) Aspects of the Tectonic Evolution of China. Geol Soc London Spec Pub 226: pp 73-100

JAHN BM, Wu F, CheN B (2000) Massive granitoid generation in Central Asia: Nd isotope evidence and implication for continental growth in the Phanerozoic. Episodes 23: 82-92

JANOUŠEK V, FARRow CM, ERBAN V (2006) Interpretation of whole-rock geochemical data in igneous geochemistry: introducing Geochemical Data Toolkit (GCDkit). J Petrol 47: 1255-1259

Kovalenko VI, Yarmolyuk VV, Salnikova EB, Kartashov PM, Kovach VP, Kozakov IK, Kozlovskiy AM, Kotov AB, Ponomarchuk VA, Listratova EN, Yakovleva SZ (2004) The Khaldzan-Buregtei Massif of peralkaline rare-metal igneous rocks: structure, geochronology, and geodynamic setting in the Caledonides of Western Mongolia. Petrologiya 12: 467-494 (in Russian)

Kovalenko VI, Yarmoluyk VV, Salnikova E, KozlovskiY AM, Kotov A, Kovach VP, Savatenkov V, Vladykin N, Ponomarchuk VA (2006) Geology, geochronology, and geodynamics of the Khan Bogd alkali granite pluton in southern Mongolia. Geotektonika 40: 450-466 (in Russian)

Kozakov IK, Kovach VP, Bibikova EV, Kirnozova TI, Zagornaya NY, Plotkina YV, Podkovyrov VN (2007) Age and sources of granitoids in the junction zone of the Caledonides and Hercynides in southwestern Mongolia: geodynamic implications (in Russia). Petrologiya 15: 126-150

Kozlovskiy AM, Yarmolyuk VV, Salnikova EB, SavatenKOV VM, KOVALENKO VI (2005) Age of bimodal and alkali granite magmatism of the Gobi-Tien Shan rift zone, Tost Range, southern Mongolia. Petrology 13: 197-203

Lamb M, Badarch G (1997) Paleozoic sedimentary basins and volcanic-arc systems of southern Mongolia: new stratigraphic and sedimentologic constraints. Int Geol Rev 39: 542-576

LAMB M, BADARCH G (2001) Paleozoic sedimentary basins and volcanic-arc systems of southern Mongolia: new stratigraphic and petrographic constraints. In: HEDRIX MS, Davis GA (eds) Paleozoic and Mesozoic Tectonic Evolution of Central Asia - From Continental Assembly to Intracontinental Deformation. Geol Soc Am Memoir 194: $117-150$

Lamb M, Badarch G, Navratil T, Poier R (2008) Structural and geochronologic data from the Shin Jinst area, eastern Gobi Altai, Mongolia: implications for Phanerozoic intracontinental deformation in Asia. Tectonophysics 451: $312-330$

Laurent-Charvet S, Charvet J, Monie P, Shu LS (2003) Late Paleozoic strike-slip shear zones in eastern central
Asia (NW China): new structural and geochronological data. Tectonics 22: 1099-1101

Laurent-Charvet S, Charvet J, Shu LS, Ma RS, Lu HF (2002) Palaeozoic late collisional strike-slip deformations in Tianshan and Altay, Eastern Xinjiang, NW China. Terra Nova 14: 249-256

Luchitskaya M, TiкHomirov P (2007) Cretaceous granitoid magmatism of north-east Asia: tectonic setting, rock chemistry, isotopy and P-T conditions of formation. Geoph Res Abstr 9

Melnikov A, Delvaux D, Travin A, Buslov MM, Vladimirov A, Smirnova L, Theunissen K (1997) Late Paleozoic-Early Mesozoic sinistral movement along the Irtysh shear zone, NE Kazakhstan. In: Tectonic Studies Group Annual General Meeting, 17-19 Dec, 1997, Durham (UK)

Melnikov A, Travin A, Plotnikov A, Smirnova L, TheunisSEN K (1998) Kinematics and Ar/Ar geochronology of the Irtysh Shear Zone in NE Kazakhstan. In: Continental Growth in the in Phanerozoic: evidence from East-Central Asia, IGCP-420 Meeting, Urumqi, China, pp 30

MiddLemost EAK (1994) Naming materials in the magma/ igneous rock system. Earth Sci Rev 37: 215-224

MielKe P, WinKLer HGF (1979) Eine bessere Berechnung der Mesonorm für granitische Gesteine. Neu Jb Mineral, Mh 471-480.

Mitrofanov FP, Kozakov IK, Palei IP (1981) Precambrian of west Mongolia and South Tuva. In: Mitrofanov FP, Kozakov IK, Palei IP (eds) Transactions of the Joint Soviet-Mongolian Scientific-Research Geological Expedition vol 32. Nauka, Leningrad, pp 90-102 (in Russian)

Mossakovsky AA, Ruzhentsev SV, Samygin SG, KherasKOvA TN (1993) Central Asian fold belt: geodynamic evolution and history of formation. Geotectonics 6: 3-33

Passchier CW, Simpson C (1986) Porphyroclast systems as kinematic indicators. J Struct Geol 8: 831-843

Pearce JA, Harris NBW, Tindle AG (1984) Trace element discrimination diagrams for the tectonic interpretation of granitic rocks. J Petrol 25: 956-983

Peccerillo A, Taylor SR (1976) Geochemistry of Eocene calc-alkaline volcanic rocks from the Kastamonu area, northern Turkey. Contrib Mineral Petrol 68: 61-81

Powell R, Holland TJB (1985) An internally consistent thermodynamic dataset with uncertainties and correlations: 1 . Method and a worked example. J Metamorph Geol 3: 327-342

RuzhentSev SV (1985) Geology of the Gobi Tien Shan and problems of South-Mongolian ocean. Izvestiya Vysshei Shkoly. Geologiya i Razvedka 6: 12-19 (in Russian)

RuzhentSev SV (2001) The Variscan belt of South Mongolia and Dzungaria. In: Dergunov AB (ed) Tectonics, Magmatism, and Metallogeny of Mongolia, London, pp 61-94 
Ruzhentsev SV, Pospelov II (1992) The South-Mongolian Variscan fold system. Geotektonika 5: 45-62 (in Russian)

Ruzhentsev SV, Badarch G, Voznesenskaya TA (1985) Tectonics of Trans-Altay zone of Mongolia. Geotektonika 4: 28-40

ŞEngör AMC, Natalin BA, Burtman VS (1993) Evolution of the Altaid tectonic collage and Paleozoic crustal growth in Eurasia. Nature 364: 299-307

Shand SJ (1947) Eruptive Rocks, Their Genesis, Composition, Classification and Their Relation to the Ore-Deposits. $3^{\text {rd }}$ edition, J. Wiley \& Sons, New York, 1-488 pp.

Shu LS, Charvet J, Guo LZ, Lu HF, Laurent-Charvet S (1999) A Large scale Paleozoic dextral strike-slip shear zone: the Aqikkudug-Weiya zone along the Northern margin of Central Tianshan belt, Xinjiang, NW China. Acta Geol Sinica 73: 148-162

Šourek J, Černý M, Rejchrt M eds (2003) Geological and geochemical mapping of Trans-Altay Gobi on the scale $1: 200,000$. MS, MRPAM, Ulaanbaatar, 1-64 pp

StreCKeISEN A, 1976. To each plutonic rock its proper name. Earth Sci Rev 12: 1-33.

Streckeisen A, Le Maitre RW (1979) A chemical approximation to the modal QAPF classification of igneous rocks. Neu Jb Mineral, Abh 136: 169-206

Sun SS, McDonough WF (1989) Chemical and isotopic systematics of oceanic basalts: implications for mantle composition and processes. In: SAUNDERS AD, NorRy MJ (eds) Magmatism in Ocean Basins. Geol Soc London Spec Pub 42: pp 313-345

Sylvester PJ (1989) Post-collisional alkaline granites. J Geol 97: 261-281

TAPPONIER P, Molnar P (1979) Active faulting and Cenozoic tectonics of the Tien Shan, Mongolia and Baykal region. J Geophys Res 84(B7): 3425-3459

Tumurtogoo O (1997): A new tectonic scheme of the Palaeozoides in Mongolia. In: Zhaqin X, Yufeng R, Xiaoping Q (Eds.). Proceedings of the $30^{\text {th }}$ Int. Geol. Congr. VSP 7, 75-82

Tumurtogoo O (2002): Tectonic map of Mongolia, scale 1 : 1000000 (with Brief Explanatory Notes, 23 pp.), Geological Information Centre MRPAM, 15 sheets, Ulaanbaatar

Wang YX, Qiu YZ, Gao JY, Zhang QA (2003) Proterozoic anorogenic magmatic rocks and their constraints on mineralizations in the Bayan Obo deposit region, Inner Mongolia. Sci China, series D - Earth Sci 46: 26-40

Webb LE, Graham SA, Johnson CL, Badarch G, Hendrix MS (1999) Occurrence, age, and implications of the Yagan-Onch Hayrhan metamorphic core complex, southern Mongolia. Geology 27: 143-146

Wei CJ, Congqiang L, Masuda A (1997) Complex traceelement effects of mixing-fractional crystallization composite processes: applications to the Alaer granite pluton, Altay Mountains, Xinjiang, northwestern China. Chem Geol 135: 103-124

Whalen JB, Currie KL, Chappel BW (1987) A-type granites: geochemical characteristics, discriminations and petrogenesis. Contrib Mineral Petrol 95: 407-419

Wilson M (1989) Igneous Petrogenesis. Harper Collins Academic, London, pp 1-466

Windley BF, Allen MB, Zhang C, Zhao Z, Wang G (1990) Paleozoic accretion and Cenozoic redeformation of the Chinese Tien Shan range, central Asia. Geology 18: 128-131

Windley BF, Kröner A, Guo JH, Qu GS, Li YY, Zhang C (2002) Neoproterozoic to Paleozoic geology of the Altai orogen, NW China: new zircon age data and tectonic evolution. J Geol 110: 719-737

Windley BF, Alexeiev D, Xiao W, Kröner A, Badarch G (2007) Tectonic models for the accretion of the Central Asian orogenic belt. J Geol Soc, London 164: 31-47

Xiao WJ, Windley BF, Badarch G, Sun S, Li J, Qin K, Wang Z (2004) Palaeozoic accretionary and convergent tectonics of the southern Altaids: implications for the growth of central Asia. J Geol Soc, London 161: 339-342

YARMOLYUK VV (1983) Late Paleozoic volcanism of continental rifting structures of Central Asia. Nauka, Moscow, pp 1-198 (in Russian).

Yuan C, Sun M, Xiao W, Li X, Chen H, Lin S, Xia X, Long X (2007) Accretionary orogenesis of the Chinese Altai: insights from Paleozoic granitoids. Chem Geol 242: 22-39

ZhANG Z, Guo Z, Liu S (1998) Age and tectonic significance of the mafic dyke swarm in the Kuruktag region, Xinjiang. Acta Geol Sinica 72: 29-36

Zhang SH, Zhao Y, Song B, Yang ZY, Hu JM, Wu H (2007) Carboniferous granitic plutons from the northern margin of the North China Block: implications for a late Paleozoic active continental margin. J Geol Soc, London 164: 451-463 